\title{
İngiliz Hukukunda Azınlık Pay Sahiplerinin Korunması ve Türk
}

\section{Hukuku ile Karşılaştirılması}

\author{
Meltem Karatepe Kaya* ${ }^{*}$
}

\section{Öz}

İngiltere'de azınlık pay sahiplerinin korunmasına ilişkin çalışmalar 1843 yılındaki Foss v Harbottle davasından beri var olmuş ve sürekli gelişim göstermiştir. 2006 yılında yürürlüğe giren İngiliz Şirketler Kanunu (Companies Act) ile uygun çözümler sunuluncaya kadar, azınlık pay sahiplerinin korunması konusunda İngiliz hukuku, anglo sakson hukuk sistemi (common law) ve çeşitli yasal düzenlemeler çerçevesinde çok sayıda reform ve gelişme geçirmiştir. Mahkeme içtihatları ile pay sahiplerinin karşılaşabileceği sorunlar ortaya konularak bu sorunların çözümü için hangi yollara başvurulabileceği düşünülmüş ve bunun sonucu olarak da azınlık pay sahiplerine tanınan temel kanuni haklar ortaya çıkmıştr. İngiltere'de azınlık pay sahiplerinin korunmasının, teorik ve varsayıma dayalı önerilerden ziyade, pratik ve gerçek olaylara dayandığı ve bu doğrultuda çözümsel önerileri içerdiği söylenebilir. Birçok koruma mekanizması pay sahipleri için koruma sağladıklarından emin olmak için kapsamlı bir şekilde test edilmiştir. İngiliz hukukunda pay sahibine bireysel olarak bahşedilmiş olan hakların yanı sıra azınlık pay sahiplerinin korunması büyük ölçüde dava yollarına dayanmaktadır. Bu makalede temel olarak İngiliz Şirketler Hukukunda mevcut olan ve azınlık pay sahiplerine mahkemeye başvurma hakkı tanıyan üç hak üzerinde durulacaktr; "türev davalar (derivative actions)", "haksız ayrımclık davası (unfair prejudice petition)", ve "tasfiye davası (the winding up)". Ayrıca Türk hukukunda azınlık pay sahiplerinin şirketlerde karşıaştı̆ı benzer sorunların nasıl çözüldüğü analiz edilerek, iki hukuk sistemi arasındaki benzerlik ve farklılıklar ortaya konulacaktır.

\section{Anahtar Kelimeler \\ İngiliz şirketler kanunu, Haksız ayrımcılık davası, Fesih davası, Türev dava, Azınlık pay sahiplerinin korunması, Haklı sebeple fesih davası}

\section{Minority Shareholders' Protection under English Law and a Comparison with Turkish Law}

\begin{abstract}
This article will focus on the UK's minority shareholder protection system. The case of Foss v. Harbottle (1843) established the principle of the protection of minority shareholders. That principle underwent numerous reforms and developments under common law and regulations until proper remedies were established in 2006 under the Companies Act. Many issues have been examined in the caselaw, and the remedies and rights for minority shareholders have been subsequently codified. As a result, it can be stated that the protection of minority shareholders in the UK includes practical and reallife suggestions from a business setting rather than theoretical and hypothetical suggestions. Many mechanisms have been extensively tested to ensure that they offer genuine protection for shareholders. Therefore, the paper will provide some background on the development of UK company law related to protection of minority shareholders. Furthermore, this part of the research will set out the current doctrinal position with regard to minority shareholder protection. Some attention will also be given to important cases. The paper will also analyze the main remedies available to minority shareholders in the UK, which are the statutory "derivative action," "unfair prejudice petition," and winding-up order."
\end{abstract}

\section{Keywords}

UK companies act, Derivative action, Unfair prejudice petition, Winding-up order, Minority shareholders' protection, Company dissolution, Just causes

* Sorumlu Yazar: Meltem Karatepe Kaya (Öğr. Gör. Dr.), İstanbul Medeniyet Üniversitesi, Hukuk Fakültesi, Ticaret Hukuku Anabilim Dalı, İstanbul, Türkiye. E-posta: meltemkaratepe.kaya@medeniyet.edu.tr ORCID: 0000-0003-3428-0293

Atıf: Karatepe-Kaya M, “ingiliz Hukukunda Azınlık Pay Sahiplerinin Korunması ve Türk Hukuku ile Karşılaştrılması” (2021) 79(1) İstanbul Hukuk Mecmuası 79. https://doi.org/10.26650/mecmua.2021.79.1.0003 


\section{Extended Summary}

This article will focus on the UK's minority shareholder protection system. It will discuss its development from a historical perspective. Therefore, this section will essentially concentrate on these legal actions: derivative action, unfair prejudice action, and the winding-up remedy. The UK's minority shareholder protection system experienced significant developments after a number of corporate law reforms. The current company law in the UK has gone through several stages of development, and the protection of minority shareholders has progressively improved at every stage, culminating in the UK Companies Act 2006. The protection of minority shareholder model in the UK heavily relies upon judicial protection. Therefore, this article will address the English law on the protection of minority shareholders and will assess whether the 2006 Companies Act has made some improvements in the area.

According to the decision in Foss $v$. Harbottle, a corporation is a legal person separate from its shareholders and owners with separate legal personality. The rule from Foss v. Harbottle is divided into two main principles: the proper claimant principle and the internal management principle. The meaning of "proper claimant" is that if a company has suffered harm, or a breach of duty has been owed to a corporation, then the proper plaintiff in those circumstances is the company itself (which reinforces the idea that a company is a separate legal entity). As a result of the proper claimant rule, even if any wrong is committed against the company, and it affects a shareholder's financial or judicial position, the shareholders cannot bring an action against the offending legal entity. Only the company has the right to sue. This situation is unfair for minority shareholders because it is the management of the company that has the authority to decide whether or not to sue someone. This is especially problematic when a majority shareholder has done a wrong to the company, in which case he will obviously not want the company's management to decide to bring an action against him. This and similar problems bring us to the reason for the existence of the derivative action under UK company law.

Despite attempts to use the rule of Foss v. Harbottle to prevent minority shareholders from bringing unnecessary actions related to the wrongs done to the company, the rule has nevertheless improved the majority shareholders' power over company decisions. This power has allowed majority shareholders to ratify their conduct even if their actions damage the interests of the minority. It is for this reason that certain exceptions to the rule of Foss v. Harbottle emerged. These exceptions were outlined by the Court of Appeal in Edwards v. Halliwell to restrict the power of the majority shareholders and offer the minority shareholders the ability to make a derivative claim and to litigate on behalf of the company in particular situations. As can be seen, in the United Kingdom, derivative action has been shaped by court decisions through deep analysis. 
Accordingly, in the first part of this article, an attempt will be made to observe and examine the developments and processes that have led to the derivative action regulated under sections 260-264 of the UK Companies Act 2006.

In the second part of this article, the research will consider the unfair prejudice petition set out in section 994 of the Companies Act 2006. This remedy allows shareholders to approach the courts directly where they have experienced unfairly prejudicial conduct. This remedy is not new to the Companies Act 2006, but it has been developed under it. Previously, in the Companies Act 1948 (section 210), this provision for shareholders was formulated as the "oppression remedy." However, the Companies Act 2006 now offers the most efficient and practical protection to minority shareholders via updated provisions.

The unfair prejudice petition will be described, and some special issues will be discussed such as who may bring this petition, the meaning of some phrases used in the unfair prejudice provision, and the petition's appearance and frequency of application in quasi-partnerships. UK caselaw regarding the unfair prejudice petition will be analyzed to show how unfair conduct and petitioners are determined by the court. The third part will analyze the winding-up remedy. Actual issues with the legal framework of protection of minority shareholders in Turkey will also be identified, and it will be explained how English law deals with a similar problem and the extent to which a similar solution can be achieved. Finally, the article will end with a conclusion. 


\section{İngiliz Hukukunda Azınlık Pay Sahiplerinin Korunması ve Türk Hukuku İle Karşılaştırılması}

\section{Giriş}

İngiltere'de azınlık pay sahiplerinin korunmasına ilişkin çalışmalar 1843 yılına Foss $v$ Harbottle $e^{1}$ davasına dayanmaktadır. Azınlık hissedarlarının korunması prensibi Foss v Harbottle davasından beri var olmuş ve sürekli gelişim göstermiştir. 2006 yılında yürürlüğe giren İngiliz Şirketler Kanunu (IKKŞ), ${ }^{2}$ uygulamada ortaya çıan sorunlara uygun çözümler sunmak için çok sayıda reform geçirmiştir. Mahkeme içtihatları ile pay sahiplerinin karşılaşabileceği sorunlar ortaya konularak bu sorunların çözümü için yasal çareler düşünülmüş ve bunun sonucu olarak da azınlık pay sahiplerine tanınan temel kanuni yollar ortaya çıkmıştır. İngiltere'de azınlık pay sahiplerinin korunmasının, teorik ve varsayıma dayalı önerilerden ziyade, pratik ve gerçek olaylara dayandığı ve bu doğrultuda çözümsel önerileri içerdiği söylenebilir. Birçok koruma mekanizması pay sahipleri için koruma sağladıklarından emin olmak için kapsamlı bir şekilde test edilmiştir.

İngiliz hukukunda pay sahibine bireysel olarak bahşedilmiş olan hakların yanı sıra azınlık pay sahiplerinin korunması büyük ölçüde dava yoluyla korumaya dayanmaktadır. Bu makalede temel olarak İngiliz Şirketler Hukukunda mevcut olan ve azınlık pay sahiplerine mahkemeye başvurma hakkı tanıyan üç dava türü üzerinde durulacak ve bu davalar ayrıntılı olarak ele alınacaktır. Bunlar, İngiliz Şirketler Kanununda (İşK) madde 260'ta yer alan “türev davalar (derivative actions)" 994'de yer alan "haksız ayrımcılık davası (unfair prejudice petition)" ", ve İngiliz İflas Yasasında (İIY) madde 122'de yer alan "tasfiye davası (the winding up)" ş̧eklindeki kanuni yollardır.

2006 yılında yürürlüğe giren İngiliz Şirketler Kanunu 260. maddesi ve devamında düzenlenen "derivative action" bu makalede "türev dava" olarak Türkçeye çevrilmiştir. Bunun en temel sebebi makalenin ilerleyen kısımlarında daha detaylı olarak açıklanacağı üzere anılan dava hakkının her ne kadar pay sahiplerine tanınan bir hak olsa da pay sahibinin bu hakk1 türevsel olarak kullanmasıdır. Nitekim pay sahibinin mahkemeye yapmış olduğu başvuru ile eğer mahkeme izin verirse yöneticilere karşı sorumluluk davası şirket adına açılmış olacak ve yargılama devam edecektir. Yani her ne kadar eylemde bulunup davayı mahkemeye taşıyan pay sahibi olsa da yöneticilere karşı dava açma hakkı şirkete aittir.

\footnotetext{
Foss v Harbottle [1843], 67 ER 189.

2006 İngiliz Şirketler Kanunu.

2006 İngiliz Şirketler Kanunu; madde 260.

2006 İngiliz Şirketler Kanunu; madde 994.

1986 İngiliz İflas Yasas1; madde 122.
} 
İngiliz Şirketler Kanunu 994. maddesinde düzenlenen "unfair prejudice petition", ise bu makalede "haksız ayrımcılık davası" olarak Türkçeye çevrilmiştir. Makalenin ilerleyen bölümlerinde de bahsedileceği üzere, her ne kadar bu dava hakkı içeriği itibariyle 6102 sayılı Türk Ticaret Kanunu (TTK) 531. maddesinde düzenlenen "haklı sebeplerle fesih" davasına benzese de sonuçları itibariyle bu davadan farklılaşmaktadır. En önemli ayrım belki de yargılama sonunda TTK 531'e göre mahkeme tarafindan verilebilecek olan fesih kararının haksız ayrımcılık davasında verilemeyecek olmasıdır ${ }^{7}$. Ayrıca kavramın İngilizcesi de haklı sebeple fesih çevirisine karşl1ık gelmemektedir. Ancak belirtmek gerekir ki TTK madde 531'e dayanarak açılan davalar, bu davalardaki taraf gerekçeleri ve Yargıtay kararları incelendiğinde her ne kadar terimsel bir benzerlik bulunmasa da İŞK madde 994 'te incelenen haksız ayrımcılık davası ile aralarında bir bağ ve benzerlikler bulunduğu söylenebilir. $\mathrm{Bu}$ husus detaylı olarak makalemizde anlatılacaktır.

1986 tarihli İngiliz İflas Yasasında yer alan "just and equitable winding up" davas1 ise "haklı gerekçelere dayanan tasfiye davası" olarak çevrilebilir. Ancak bu makalede karışıklık yaşanmaması adına "tasfiye davası" olarak kullanılacaktır. Bu dava her ne kadar TTK madde 531'de düzenlenen haklı sebeple fesih davası ile terim olarak ve sonuçları itibariyle benzerlik taşısa da İngiliz hukukunda şu an haksız ayrımcılık davasının olumsuz sonuçlandığı hallerde başvurulan bir dava yoludur. Ayrıca İflas Kanunda düzenlenmiş olması hasebiyle de şirketler hukukunun düzenleme alanına giren haklı sebeple fesih davasından farklılaştığı ve bir şirketin tamamen sona yaklaştı̆̆1 durumda başvurulan bir dava hakk1 olduğu söylenebilir. Aslında özü itibariyle bakıldığında İşK madde 994 düzenlenen haksız ayrımcılık davası ile İIY 122. maddede düzenlenen tasfiye davası birlikte düşünüldügünde ancak TTK madde 531'de yer alan haklı sebeple fesih davasına karşıllk geldiği söylenebilir ${ }^{10}$. Yani bizim hukukumuzda bir madde ile düzenlenen hususlar İngiliz hukukunda farklı kanunlarda ve iki farklı dava hakkı şeklinde düzenlenmiştir ${ }^{11}$.

Bu dava haklarına ek olarak, 2006 yılında yürürlüğe giren İngiltere Şirketler Kanunu kapsamında, her bir azınlık pay sahibinin kendilerine bir tür koruma sağlayan belirli yasal haklara sahip olduğu belirtilmelidir. Bu haklar pay sahiplerinin mahkemeye başvurmasına gerek kalmaksızın onlara şirketle alakalı hususlarda koruma sağlayan haklardır.

\footnotetext{
2006 İngiliz Şirketler Kanunu; madde 994.

Bu konuya ilişkin ayrıntılı bilgi aşağıda verilecektir.

8 Cem Veziroğlu, 'Buy-Out of the Oppressed Minority's Shares in Joint Stock Companies: A Comparative Analysis of Turkish, Swiss and English Law' (2018) 19 European Business Organization Law Review 527, 533.

1986 İngiliz İflas Yasası; madde 122.

10 Veziroğlu (n 9) 533.

$11 \mathrm{Bu}$ hususla ilgili ayrıntılı bilgi makalenin devamında verilecektir.
} 
İŞK ile sahip oldukları pay oranına bakılmaksızın, her pay sahibine sağlanan haklar;

- 2006 y1lı İŞK 306. maddede düzenlenen pay sahibinin mahkemeden genel kurulu toplantıya çağırmasını isteme hakk1 ${ }^{12}$,

- 310. maddede düzenlenen genel kurula ilişkin bilgilendirilme hakk ${ }^{13}$,

- 431. maddede düzenlenen yıllık mali tablonun bir kopyasına sahip olma hakk1 ${ }^{14}$,

- 116. madde 2. fikrada düzenlenen pay sahipliği kaydını ve pay sahipliği isminin indeksini ücretsiz olarak inceleme hakkı ve ücret talep edildikten sonraki 10 gün içinde pay sahiplerinin sicilinin bir kopyasını talep etme hakkı şeklinde sıralanabilir ${ }^{15}$.

Ayrıca, İ̧SK'da belli bir pay oranına sahip olmak şartı ile pay sahiplerine verilen birtakım haklar da mevcuttur. Örneğin; İŞK madde 303 uyarınca şirketteki oy haklarının en az yüzde 10'unu temsil eden pay sahiplerinin (12 aydan daha uzun süredir bir genel kurul toplantısı yapılmadığı takdirde bu oran yüzde 5 azalır) genel kurulu toplantıya çağırma hakkı vardır ${ }^{16}$. Yine, madde 314 uyarınca şirkette yüzde 5 payı temsil eden her bir pay sahibinin yazılı bir açıklama yapma hakkı vardır ${ }^{17}$. Ayrıca 306. madde ile İşK şirkette yüzde 10'dan fazla payı temsil eden her bir pay sahibine şirketin yıllık hesaplarını denetletme hakkı vermiştir ${ }^{18}$. Ek olarak madde 283 'e göre şirkette yüzde 25 'ten fazla payı temsil eden her bir pay sahibinin, şirketin ana sözleşmesinde değişiklik yapılması gibi özel sayı gerektiren kararları engelleme hakk1 vardir ${ }^{19}$.

Görüldüğü üzere İngiliz hukukunda azınlık pay sahiplerine tanınan bazı haklar için belli oranda bir paya sahip olma şartı aranırken, birçok hak için bu şart aranmamış ve sahip olduğu payların oranına bakılmaksızın tüm pay sahiplerine bu haklar tanınmıştır. Pay sahiplerinin herhangi bir sorunla karşılaştıklarında başvurabileceği olası kanuni yollardan olan "türev davalar", "haksız ayrımcılık davası" ve "tasfiye davası" için de herhangi bir pay sahipliği oranı şart koşulmamıştır. Her bir pay sahibi şirkette sahip olduğu pay oranına bakılmaksızın bu dava yollarına başvurabilir ve mahkemede hakkını arayabilir.

\footnotetext{
2006 İngiliz Şirketler Kanunu; madde 306

32006 İngiliz Şirketler Kanunu; madde 310

142006 İngiliz Şirketler Kanunu; madde 431.

152006 İngiliz Şirketler Kanunu; madde 116/2.

162006 İngiliz Şirketler Kanunu; madde 303.

172006 İngiliz Şirketler Kanunu; madde 314

182006 İngiliz Şirketler Kanunu; madde 306.

192006 İngiliz Şirketler Kanunu; madde 283.
} 
$\mathrm{Bu}$ makalenin ilk kısmında öncelikle İngiltere'de azınlık pay sahiplerinin korunmasına ve gelişim sürecine ilişkin genel bir bilgi verilecek ve devamında İŞK 2006'nın 260-264 maddelerinde düzenlenen bir kanun yolu olan "türev dava (derivative action) "20 ${ }^{20}$ incelenecek ve bu hakkın ortaya çıkışına yol açan gelişmeler ile İngiliz hukukundaki süreçler gözlemlenmeye ve değerlendirilmeye çalışılacaktır.

Bölümün ikinci kısmında ise İşK'nın 994. maddesinde belirtilen "haksız ayrımc1l1k davası (unfair prejudice petition)" "21, ele alınacaktır. Bu dava kapsamında pay sahiplerine, şirket içinde kendilerine yönelik haksız ve baskıcı davranışlarla karşılaşmaları halinde doğrudan mahkemeye başvurma hakkı tanımaktadır. Bu çözüm yolu her ne kadar isim olarak 2006 y1lında yürürlüğe giren İngiliz Şirketler Kanunu için yeni olsa da aslında kurum olarak daha önce, Şirketler Kanunu 1948'de (madde 210), pay sahiplerine yönelik baskıcı tutumlar karşısında bir çözüm olarak yolu olarak formüle edilmiştir. Ancak 2006 tarihli Şirketler Kanununda yer bulan "haksız ayrımcılık davası", azınlık pay sahipleri için daha kapsamlı, daha etkin ve pratik korumayı sağlayan kanuni bir çözüm sunmaktadır. Bölümde, ayrıca, İngiliz hukukunda azınlık pay sahiplerine tanınan bir çözüm yolu olan haksız ayrımcılık davasına ilişkin olarak detaylı analiz yapılacak ve bu hakkı kimlerin, ne şekilde, hangi hallerde kullanabileceği ve bu talebe yönelik mahkemenin nasıl bir karar vereceği gibi sorulara örnek karar tahlilleri de kullanılarak cevap aranılacaktır.

Üçüncü kısımda pay sahiplerine tanınan bu iki hakkın arasındaki farklılıklar analiz edilirken, dördüncü kısımda ise "tasfiye davası (the winding up)"22 analiz edecektir. Son olarak da Türk hukukunda azınlık pay sahiplerine tanınan dava hakları belirtilecek ve kıyaslama yapılarak öneriler sunulacaktır. Belirtmek gerekir ki bu makalede kıyaslama yapılan şirketler, İngiltere'de yer alan ve davalara konu olan halka açık olmayan şirketler ve Türkiye'de yer alan halka açı olmayan anonim şirketlerdir.

\section{1. İngiliz Hukukunda Azınlık Pay Sahiplerinin Başvurabileceği Hukuki Yollar}

\subsection{Ortak Hukuk Kuralları Çerçevesinde Azınlık Pay Sahiplerine Tanınan Dava Hakkı}

İngiliz hukukunda hem "common law" (ortak hukuk), hem de "Companies Act"(şirketler kanunu) açısından azınlık pay sahipleri çoğunluğun şirket içerisindeki eylemlerine karşı korunmuştur. İngiltere'de azınlık pay sahiplerinin korunması için farklı mekanizmalar bulunmaktadır. Bunlar aşağıda sırasıyla incelenecektirir ${ }^{23}$.

\footnotetext{
2006 İngiliz Şirketler Kanunu; madde 260.

2006 İngiliz Şirketler Kanunu; madde 994.

221986 İngiliz İflas Yasası; madde 122.

23 Rafael La Porta, Florencio Lopez-de-Silanes, Andrei Shleifer and Robert W.Vishny, 'Law and Finance' (1998) 106 Journal of Political Economy, 1129.
} 
Olası bir sorunda, pay sahiplerinin hakları kişisel olarak ihlal edildiğinde yahut askıya alındığında, pay sahiplerince başvurulabilecek çözüm yollarından biri "personal action" yani kişisel davadır ${ }^{24}$. Pay sahiplerinin haklarının ihlali halinde kendilerini korumaları için doğrudan başvuru hakları saklıdır. İngiliz Şirketler Kanununda ve ortak hukukta kişisel hakların genel bir tanımını bulmak mümkün değildir. Her bir mevcut vaka için mahkeme kişisel hakkın tanımını yapmaktadır. Böylece zamanla farklı eylemlerin kişisel dava gerekçesi olarak değerlendirilmesi sonucu içtihatlar ortaya çıkmıştır ${ }^{25}$. Ancak, Prudential Assurance Co Ltd ve Newman Industries Ltd. ${ }^{26}$ davasında (No. 2) görülebileceği gibi, azınlık hissedarlarına kişisel dava açma izni mahkeme tarafindan sadece şirketi ilgilendirmeyen ve şirkete ilişkin bir zararın söz konusu olmadığı hususlarda verilmiştir ${ }^{27}$.

İkinci olarak, şirketin menfaatlerine yönelik bir saldırı var ise yahut şirketin işleyişinde bir zarar meydana gelirse hissedarlar mahkemeye türev dava açma talebiyle başvurabilirler. Bu başvuru hakkı ile kanun koyucu, azınlık pay sahiplerine kendi paylarının değerini etkileyen bir durumdan dolayı şirket adına ve hesabına yargılama yöntemlerine başvurabilmelerine olanak sağlamıştır. Kural olarak azınlık pay sahiplerinin şirket adına ve hesabına yönetim kurulu kararı olmaksızın mahkemeye başvurma hakkı yoktur. Ancak, ileride inceleneceği üzere mahkemelere intikal eden olaylar ve bunlara ilişkin verilen kararlar bu kuralın bazı istisnalarını getirmiştir. Buna göre, şirkete karşı verilen bir zararda bu zarar azınlık pay sahibinin paylarını da etkileyeceği için eğer şirket herhangi bir nedenle yargı yoluna gitmezse, şirket adına mahkemeye gitme hakkını azınlık pay sahibi kullanabilmektedir ${ }^{28}$. Esasen, azınlık pay sahibi mahkemeden şirket adına davaya devam edilebilmesi için izin istemektedir. Her ne kadar iddiayı pay sahibi mahkemeye taşımış olsa da mahkemenin davanın devamına "permission" yani izin vermesi halinde artık dava şirket adına ve hesabına devam etmektedir. Örneğin, şirket hesaplarında bir oynama halinde yahut şirkete ait bir gayrimenkulün devrinde dolandırıcılık yapıldığı gerekçesi ile; eğer ki kusuruyla şirkete zarar verdiği iddia edilen şahıslar aynı zamanda şirketi kontrol edenlerse ve bu yolla şirketin dava açması engelleniyorsa, her bir pay sahibi mahkemeye başvurarak şirket adına dava açılmasını ve bu olası

\footnotetext{
24 Bknz Smith v Croft No. 2 [1988], Ch. 114; Prudential Assurance Co. Ltd v Newman Industries Ltd [1982], Ch. 204.

25 J. Paul Sykes, 'The continuing paradox: a critique of minority shareholder and derivative claims under the Companies Act 2006' (2010) 29 Civil Justice Quarterly 205-234, 210.

26 Prudential Assurance Co. Ltd v Newman Industries Ltd [1982], Ch. 204.

27 Alan Dignam, Andrew Hicks ve S.H. Goo, Hicks \& Goo's Cases and Materials on Company Law (Oxford University Press 2011), 426.

28 Burada kastedilen şirketin uğramış olduğu zarar neticesinde pay sahiplerinin karşı karşıya kalacağı yansıyan bir diğer ifade ile dolaylı zarardır. Türk hukukunda kanun koyucu belli bir oy oranı aranmaksızın tüm pay sahiplerine doğrudan sorumluluk davası açma hakkı tanımıştır. Şöyle ki, 6102 sayılı Türk Ticaret Kanunu madde 555 kapsamında yönetim kurulu üyelerinin eylemleri dolayısıyla şirketin uğramış olduğu zarardan dolayı, tazminatın şirkete ödenmesi şartıyla pay sahipleri doğrudan mahkemeye başvurarak yönetim kurulu üyelerinin aleyhine sorumluluk davası açabilirler. Türk hukukuna ilişkin ayrıntılı açıklama ilerleyen bölümlerde yapılacaktır.
} 
olayların araştırılmasını talep edebilir ${ }^{29}$. Ancak belirtilmelidir ki her ne kadar bu hak pay sahiplerine verilmiş olsa da mahkemenin davaya şirket adına ve hesabına devam edilmesine izin verdiği haller oldukça sınırlıdır ${ }^{30}$.

Üçüncü çözüm yolu olarak, 2006 tarihli İşK madde 994 ile düzenlenen "haksız ayrımcılık davası" söylenebilir ${ }^{31}$. Her bir pay sahibi, şirket işlerinin haksız bir şekilde yürüdüğü veya yürütüldüğü ve bu durumun genel olarak bütün şirket hissedarlarının veya sadece bazı hissedarlarının (en azından kendisinin) çıkarlarına zarar verdiği gerekçesiyle, 994. maddede yer alan haksız ayrımcılık davasını açabilir. Bu davanın en yaygın örnekleri bir azınlık hissedarının şirketin yönetiminden dışlanması veya şirket tarafindan çoğunluğa aşırı bir ücret ödenmiş olduğu gerekçesiyle açılan davalardir.

Son olarak, azınlık pay sahipleri "tasfiye davası" açarak mahkemeden şirketin tasfiyesine karar verilmesini talep edebilirler. Bu başvuru yolu "haksız ayrımcılık davası" hükümlerinin ortaya çıkmasından sonra azınlı pay sahiplerince oldukça seyrek başvurulan bir yol olmuştur. Nitekim her iki iddia da başvuru sebepleri bakımından benzer olsa da "haksız ayrımcıllk davası" sonucunda mahkeme tarafindan verilebilecek kararlar göz önünde bulundurulduğunda hem daha pratik hem de şirketin tasfiyesine kadar varmayan yapıcı çözüm yolları içermektedir ${ }^{32}$.

Aşağıda İngiliz hukukunda azınlık pay sahiplerinin korunmasının daha iyi anlaşılabilmesi için Foss V Harbottle kuralı ve istisnaları analiz edilecektir

\subsubsection{Foss V Harbottle Kuralı ve İstisnaları}

Azınlık pay sahipleri için koruma mekanizmaları İngiltere'de ortak hukuk kuralları çerçevesinde y1llardır mevcuttur. Şirket tüzel kişiliği ve şirket yönetim kurulu üyelerinin sınırlı sorumluluğu gibi kavramların doğumu İngiliz mahkemelerince verilen Salomon v Salomon \& Co Ltd. ${ }^{33}$ davasına dayanmakta iken, Foss v Harbottle ${ }^{34}$ davası da azınlık pay sahiplerine verilen dava haklarının doğumu açısından önem arz etmektedir. Zira bu dava neticesinde bir şirket ayrı bir tüzel kişilik olarak kabul edildi, yani üyelerinden (pay sahipleri ve yöneticilerden) ayr1 yasal haklar ve sorumluluklarla donatılmış bir 'tüzel kişi' haline geldi ${ }^{35}$. Foss v Harbottle davasında

\footnotetext{
29 İngiliz şirketler hukukunda ve ortak hukukta, azınlıkların korunması anlamında oldukça önemli bir yeri olan türev davaya ilişkin detaylı incelemeler ilerleyen bölümlerde yapılacaktır.

30 David Kershaw, 'The Rule in Foss v Harbottle is Dead: Long Live the Rule in Foss v Harbottle' (2015) Journal of Business Law, 274.

312006 İngiliz Şirketler Kanunu; madde 994.

32 Anthony O. Nwafor, 'The unfair prejudice remedy - a relief for the minority shareholders' (2011) 22 University of Botswana Law Journal 37, 39.

33 Salomon v Salomon \& Co Ltd [1897] AC 22 (HL).

34 Foss v Harbottle [1843], 67 ER 189.

35 A.J Boyle, John Birds ve diğerleri., Boyle \& Birds' Company Law (9. Bas1, Jordan Publishing 2014), 58.
} 
verilen karara göre, bir şirket pay sahiplerinden ve yöneticilerinden ayrı bir tüzel kişidir. Foss v Harbottle kuralı iki ana ilkeye ayrılmıştır: "proper claimant principle" ve "internal management principle" 36; yani "uygun davacı ilkesi" ve "iç yönetim ilkesi”. Uygun davacı ilkesinin anlamı, eğer bir şirket zarar gördüyse veya şirkette yöneticilerin görev ihlali söz konusu ise o zaman bu koşullarda uygun davacı yani davayı açmakla yetkili kişi şirketin kendisidir. Uygun davacı ilkesinin bir sonucu olarak, şirketi ilgilendiren işlerde, şirket aleyhine hukuka aykırı bir eylem veya işlem yapılmış olsa ve bu eylem veya işlem pay sahiplerinin mali veya hukuki pozisyonunu etkilese bile örneğin; yönetim kurulu üyelerinin kusurlu eylem ve işlemleriyle şirkete zarar vermeleri halinde bile pay sahipleri bu hatayı yapan kişiye karşı şirket adına dava açamazlar ${ }^{37}$. Dava açma hakkı yalnızca şirkete aittir. Bu durum azınlık hissedarları için haksızlıktır, çünkü şirket adına ve hesabına dava açmaya karar verme yetkisi şirketin yönetim kurulundadır. Bu durum, pay oranı olarak çoğunluğu temsil eden hâkim ortaklar şirkete karşı kusurlarıyla hukuka aykırı eylem ve işlem yaptığında, şirket yönetiminin bu ortağa karşı bir dava açılmasına karar vermesi ve harekete geçmesi pratikte zor olduğu için özellikle azınlık pay sahipleri bakımından zor bir durumdur $^{38}$. İşte bu ve benzeri sorunların çözümüne yönelik atılan adımlar İngiltere şirket hukukunda azınlık pay sahiplerinin mahkemeye türev dava izni başvurusunda bulunabilmesi için basamak olmuştur ${ }^{39}$.

Foss v Harbottle davası aynı zamanda çoğunluk payı elinde bulunduran hâkim ortakların şirket kararları üzerindeki gücünü arttırmak suretiyle şirketler hukukunda "çoğunluk kuralının" ${ }^{40}$ ortaya çıkmasına sebep olmuştur ${ }^{41}$. Bu kurala göre, genel kurula katılan pay sahiplerinin çoğunluğu şirketle ilgili herhangi bir konuda nihai kararını verme yetkisine sahiptir ve pay sahiplerinin çoğunluğu şirketin iradesini kontrol eder ${ }^{42}$. Çoğunluk kuralı, bir şirket içindeki karar alma gücünün, genel kurul toplantısında veya yönetim kurullarında oyların yarısından fazlasını kontrol edenlere ait olduğu sonucunu ortaya çıkarır. Bu kurala göre çoğunluğun kararları ve seçimleri her zaman azınlığın kararlarının üzerinde olacaktır ${ }^{43}$. Çoğunluk payı elinde bulunduran ortakların bu kuraldan aldıkları güç ile şirketteki eylemleri azınlığın çıkarlarına zarar

36 Bknz Edwards v Halliwell [1950], 2, All ER 1064; Lord Davey’in Burland v Earle [1902], AC 83 davasındaki görüşü.

37 Uygun davacı ilkesinin bir özelliği de Percival v Wright davasında anıldığı üzere yöneticilerin dikkat ve özen yükümlülüğünün şirket ortaklarına yani pay sahiplerine karşı değil şirkete karşı olmasıdır. Dava, yöneticilerin dikkat ve özen yükümlülüğünün pay sahiplerine değil şirkete olduğunu vurgulamış ve aynı zamanda temsil görevinin de yalnızca şirkete karşı olması gerektiğini ortaya koymuştur. Bknz Ben G. Pettet ve diğerleri, Pettet's Company Law (1. Bası, Pearson Longman 2009), 216.

38 Kershaw (n 31) 274.

39 ibid.

40 İngiliz hukukunda "majority rule" olarak ifade edilmektedir.

${ }^{41}$ Kenneth A. Kim, P. Kitsabunnarat-Chatjuthamard ve John R. Nofsinger, 'Large Shareholders, Board Independence, and Minority Shareholder Rights: Evidence from Europe' (2007) 13 Journal of Corporate Finance 859, 862.

42 Arad Reisberg, 'Derivative Claims under the Companies Act 2006: Much Ado about Nothing?' [2009]; 'Rationality in Company Law: Essays in Honour of D.D. Prentice', J. Armour, J. Payne, Hart Publishing, 2009; University College London Law Research Paper No. 09-02<Erişim SSRN: https://ssrn.com/abstract=1092629> Erişim tarihi 06/12/2020.

43 Reha Poroy, Ünal Tekinalp ve Ersin Çamoğlu, Ortaklıklar Hukuku (13. Bası, Beta 2014), 192. 
verse bile davranışlarının şirket tarafından onaylanmasına izin verilmiştir. Buna göre şirket yöneticileri yapmış oldukları usulsüzlük neticesinde azınlık pay sahiplerine veya şirkete zarar verse bile pay sahiplerinin yöneticiler aleyhine dava açma hakkı yoktu. Şirketin kendisi uygun davacıydı ve bu hukuksuz eyleme karşı dava açıp açmayacağına karar verme yetkisi sadece şirkete aitti. Tek yol şirket organlarında karar alınarak şirket adına ve hesabına mahkemeye başvurulmasıydı.

Zamanla azınlık pay sahipleri bu prensipler neticesinde mağduriyetler yaşamış ve azınlık pay sahiplerinin karşılaştığ Harbottle davasında oluşturulan bu kurallara bazı istisnalar ortaya çıkmıştır. $\mathrm{Bu}$ istisnalar, çoğunluk payı elinde bulunduran pay sahiplerinin şirketteki gücünü kısıtlamak için azınlık pay sahiplerine mahkemeye türev dava açmak için başvuruda bulunulmasına izin vermeyi kapsamaktadır. Böylece şirket adına belirli durumlarda mahkemeden dava açılmasına izin alınması hakkının azınlık pay sahiplerine verilmesi için Edwards v Halliwell ${ }^{44}$ davasında Temyiz Mahkemesi tarafindan ana hatlarıyla belirtilmiştir ${ }^{45}$.

Edwards v Halliwell davasında ${ }^{46}$ Jenkins LJ, Foss v Harbottle davasında ortaya çıkan kurala yönelik, pay sahiplerinin doğrudan ve dolaylı zararlarının varlığında mahkemeye başvurmalarına olanak sağlayan dört istisna belirledi. Buna göre eğer şirketin amacı ve işletme konusu dışında yapılan bir işlem varsa ${ }^{47}$, ağırlaştırılmış nisap gerekli ise $\mathrm{e}^{48}$, şikayet edilen eylem pay sahiplerinin kişisel haklarını pay sahipliği sıfatına yönelik olarak ihlal ediyorsa ve azınlık pay sahiplerine yönelik yapılan hileli bir davranış varsa ve bu davranışın kaynağı şirketi yöneten çoğunluksa ${ }^{49}$ bu durumlarda şirketin tüzel kişilik perdesi kaldırılarak pay sahipleri mahkemeye başvurma hakkına sahip olabilir ${ }^{50}$. Jenkins LJ azınlığa karşı ortada şirket aracıllğ̆ıla yöneticilerin eylemleri sonucu ortaya çıkan bir dolandırıcılık eylemi var ise bu durumun ancak Foss v Harbottle davasındaki kurala istisna olabileceğini ve ancak bu durumda azınlık pay sahiplerinin mahkemeye başvurabileceğini savunmuştur. Çünkü sadece bu halde azınlık pay sahiplerinin haklarının ihlali şahsi değil şirketi ilgilendirmektedir ve yöneticiler bu ihlali şirketi kullanarak yapmışlardır.

\footnotetext{
44 Edwards v Halliwell [1950], 2, All ER 1064.

45 Prabirjit Sarkar, 'Common law vs. Civil law: which system provides more protection to shareholders and promotes financial development?' (2017) 2 Journal of Advanced Research in Law and Economics 143, 151.

46 Edwards v Halliwell [1950], 2, All ER 1064.

47 Bknz Hutton v West Cork Railway Co. Ltd (1883), 23, Ch. D 654 (ultra vires); and Oregum Gold Mining Co. v Roper [1892], AC 125.

48 Bknz Edwards v Halliwell [1950], 2 All ER 1064.

49 Nitekim Cook v Deeks davasında yöneticilerin ve çoğunluk hissedarların azınlık pay sahiplerine yönelik hileli eylemleri sonucu azınlık pay sahipleri yöneticilere karşı dava açma hakkını kullanmıştır.

50 $\quad$ Pettet ve diğerleri (n 38) 216.
} 
Yine Jenkins LJ'a göre diğer 3 istisna sonucu pay sahipleri şirket adına ve hesabına mahkemeye başvuramaz ancak kendileri şahsi olarak yöneticilere yahut diğer sorumlulara karşı dava açabilirler ${ }^{51}$.

Sonuç olarak ortak hukukta davalar neticesi ortaya çıkan azınlık pay sahiplerinin başvurabileceği iki farklı yol vardır. Bunlardan biri şahsi dava hakkıdır. MacDougall v Gardiner ${ }^{52}$ davasında, Mellish LJ'nin kararında da belirtildiği gibi, her bir pay sahibi, hakkı ihlal edildiğinde eğer doğrudan ve kişisel bir zarar görüyorsa dava açma hakkına sahiptir ${ }^{53}$. Pay sahiplerine tanınan kendi adına dava açma hakkının dayanağ1 şirketin ana sözleşmesinden veya şahsen taraf olduğu bir sözleşmeden kaynaklanabilir. Örneğin, kâr payı ilan edilmiş ancak hissedarlara ödenmemişse ödemenin yapılması için pay sahipleri dava açabilirler ${ }^{54}$. Görülebileceği gibi, pay sahipleri yalnızca şirketin faaliyetleri nedeniyle doğrudan ve şahsi olarak zarar görmeleri halinde mahkemeye şahsi hak talebinde bulunabilirler ${ }^{55}$. Bunun yanında mahkemeye şirket adına davaya devam etme izni almak için türev dava açabilirler.

\subsubsection{Ortak Hukuk Kuralları Çerçevesinde Azınlık Pay Sahiplerine Tanınan Türev Dava Hakkı}

2006 İngiliz Şirketler Kanunu kapsamında değiştirilerek yeniden düzenlenen türev dava hakk1, 2006'dan önce ortak hukuk kuralları çerçevesinde uygulama alanı buluyordu. Ancak bu hak karmaşık prosedürü ve ağır başvuru şartları nedeniyle azınlık pay sahipleri tarafindan pek tercih edilmiyordu. $\mathrm{Bu}$ nedenle bu hakka dayanarak mahkemeye yapılan başvurular nadirdi. Ayrıca azınlık pay sahipleri yüksek yargılama giderlerini kendileri ödemek zorunda kaldılar ve bu mali yükümlülük hakkın kullanımını azaltt1 ${ }^{56}$.

Ortak hukukta bir azınlık tarafından türev dava açılması iddiasıyla mahkemeye gidilebilmesi için davacı pay sahibinin hem aleyhine yapılmış hileli davranışları hem de bu davranışların şirkette payların çoğunluğunu elinde bulunduran şirket yöneticileri tarafından yapıldığını kanıtlaması gerekiyordu. Ayrıca bu hakkın amacı azınlık pay sahiplerinin değil, şirketin menfaatlerinin korunması idi ${ }^{57}$. Bir kişi türev dava açmak için mahkemeye gittiği zaman haklı görülse ve mahkeme davanın devamına karar verip davayı onaylasa bile zararın giderilmesi amacıyla davalılarca ödenen tazminat

\footnotetext{
Derek French, Stephen W. Mayson ve Christopher L. Ryan, Mayson, French \& Ryan On Company Law (30. Bas1, Oxford University Press 2013), 559.

52 MacDougall v Gardiner (1875), 1, Ch. D 13

53 Alan J. Dignam ve John P. Lowry, Company Law (8. Bas1, Oxford 2014), 190.

54 Bknz Wood v Odessa Waterworks Co. (1889), 42, Ch. D 636.

55 D Kershaw (n 31) 280.

56 Arad Reisberg, 'Funding Derivative Actions: A Re-Examination of Costs and Fees as Incentives to Commence Litigation' (2004) 4 Journal of Corporate Law Studies 346, 348.

57 Julia Tang, 'Shareholder remedies: demise of the derivative claim?' (2012) 1 (2) UCL Journal of Law and Jurisprudence $178,180$.
} 
şirkete ödeniyordu ${ }^{58}$. Bu durum Chadwick tarafindan Cooke v Cooke $e^{59}$ davasında şu şekilde ifade edilmektedir: eğer bir azınlık pay sahibi türev dava açmak istiyorsa ancak ve ancak şirket adına "temsil kapasitesini haiz" bir kişi olması şartıyla davayı açabilir. Dava konusu olay neticesinde zarar görmüş olsa dahi yargılamanın sonunda kendi kişisel durumunda doğrudan bir iyileştirme mümkün değildir ${ }^{60}$. Bu durumda, davacı azınlık pay sahibi şirket adına, şirket temsilcisi gibi hareket etmiş ve şirket için tazminat talep etmiştir ${ }^{61}$.

Davacının şirket adına davaya devam edebilmesi için şirkette kontrolü elinde bulunduran pay sahiplerinin yaptıkları hileli işlem veya davranışları ispat etmeleri gerekmektedir ${ }^{62}$. Ancak, ortada iddia edildiği gibi hileli bir işlem veya davranış olsa dahi iddia edilen hususların yönetim kurulu veya genel kurul üyelerince üzerinin kolaylıkla kapatılabileceği ve dolayısıyla kanıtlanmasının çok kolay olmadığını ifade etmek gerekir ${ }^{63}$. İkinci bir husus da davacı pay sahibi tarafından iddia edilen hileli işlem veya davranışların, şirketi kontrol eden biri tarafından yapıldığının kanıtlanması gerekmektedir ${ }^{64}$.

$\mathrm{Bu}$, davacı pay sahibinin şirkette haksız bir işlem yapıldığını ve bu haksızlıkların şirketi kontrolü altında tutan kişilerce yapıldığını ve bu haksız eyleme karşı şirket tarafından dava açılmasının aynı kişilerce engellendiğini kanıtlaması gerektĭği anlamına gelmektedir ${ }^{65}$. Bu durum Burland $v$ Earle davasında da belirtilmektedir ${ }^{66}$.

$\mathrm{Bu}$ iki zorluğun yanında ortak hukuk kuralları çerçevesinde türev dava açma yoluna başvurulmasının nadiren karşılaşılan bir durum olmasının altında yatan başka sebepler de vardı. Bunlardan biri ve belki de en önemlisi, türev dava açma talebiyle mahkemeye başvurarak, şirket adına davaya devam etme izni isteyen azınlık pay sahiplerinin ödemek zorunda kaldığ 1 yüksek dava giderleriydi ${ }^{67}$. Nitekim eğer mahkeme kanıtları yeterli görmez ve davaya şirket adına devam edilmesine

\footnotetext{
58 Mahmoud Almadani, 'Derivative actions: does the Companies Act 2006 offer a way forward?' (2009) 30 Company Lawyer $131,132$.

59 Cooke v Cooke [1997], 2 BCLC 28.

60 French, Mayson ve Ryan (n 52) 560.

${ }^{61}$ Aslında burada söz konusu olan TTK madde 555'te olduğu gibi dolaylı zararların varlığında pay sahibinin, tazminatın şirkete ödenmesi şartıyla dava açmasıdır.

62 Nicholas Bourne, Bourne on Company Law (6. Bas1, Routledge 2013), 229.

63 Cook v Deeks [1916], 1 AC 554

${ }^{64}$ Burland v Earle [1902], AC 83; Edwin C. Mujih, 'The new statutory derivative action: a delicate balancing act: Part 1' (2012) 33 (3) Company Law, 76; Victor Joffe, Minority Shareholders (1. Bası, Oxford 2008), 34.

65 Andrew Keay and Joan Loughrey, 'Something old, something new, something borrowed: an analysis of the new derivative action under the Companies Act 2006' (2008) 124 The Law Quarterly Review 469, 475.

${ }_{66}$ Burland v Earle [1902], AC 83. Davadaki ifadeler șu şekildedir: “...But an exception is made to the second rule, where the persons against whom the relief is sought themselves hold and control the majority of the shares in the company, and will not permit an action to be brought in the name of the company. In that case the courts allow the shareholders complaining to bring an action in their own names."

${ }_{67}$ Reisberg, 'Funding Derivative Actions: A Re-Examination of Costs and Fees as Incentives to Commence Litigation' (n 57) 348.
} 
izin vermez ise yargılama giderlerinin tamamının mahkemeye başvuran azınlık pay sahibi tarafından karşılanması gerekiyordu. İkincisi, davacının mahkemeye taşıdığı olaylarda bir kusuru olmamaliyd ${ }^{68}$.

İngiliz Şirketler Kanununu hazırlayan Hukuk Komisyonu da bu prosedürlerin "karmaşık ve uzun" olduğunu bildirmiştir. ${ }^{69} \mathrm{Bu}$ prosedürün ve gerekliliklerin dava süresini uzattığını ve ayrıca dava giderlerini artırdığını iddia etmiştir. Bu nedenle Komisyon, hissedarlar için daha pratik ve erişilebilir olan yenilenmiş ve modern bir türev dava açma yolunun kurumunun yasada düzenlenmesini önermiştir ${ }^{70}$. Bununla birlikte, doktrinde de görüşlerin ortak hukuk çerçevesinde başvurulan türev dava açma yolunun zor bir prosedür olduğu konusunda hemfikir olduğu belirtilmelidir ${ }^{71}$. İşte tüm bu sorunlar 2006 İŞK madde 260 ve devamında yeni bir türev dava hakk1 düzenlenmesine sebebiyet vermiştir ${ }^{72}$.

\subsection{3 İngiliz Şirketler Kanununda Azınlık Pay Sahiplerine Tanınan Dava Hakları}

\subsubsection{1 İngiliz Şirketler Kanunu Çerçevesinde Türev Dava Hakkı (Statutory Derivative Action)}

Azınlık pay sahiplerine yöneticilerin eylemlerini denetleyebilme imkânı tanıyan türev dava hakkı 2006 tarihli İngiliz Şirketler Kanunu ile ilk kez İngiltere'de bir kanunda ayrıntılı olarak düzenlenmiştir. 2006 tarihli İngiliz Şirketler Kanununun 260-264 maddelerinde ${ }^{73}$ düzenlenen bu yeni türev dava azınlık pay sahiplerinin korunmasını önemli ölçüde arttırmıştır ${ }^{74}$.

İngiltere Hükümeti'nin 2006 Şirketler Kanunu'nda türev dava hakkını düzenlemekteki amacı, makul istekleri olan ancak gereksiz davalardan kaçınmak isteyen pay sahiplerine bir koruma sağlamaktı. 2006 tarihli Şirketler Kanunun 260. maddesine göre, şirkette belli bir pay oranı aranmaksızın her bir pay sahibi; ihmal, temerrüt, görev ihlali veya eski veya mevcut görevde olan bir müdürün güven ihlali

\footnotetext{
Bu durum İngiliz hukukunda "clean hands" olarak ifade edilmektedir.

69 Law Commission, 'Shareholder Remedies' (Law Com. No. 246, 1997), para. 6.4.

70 Law Commission, 'Shareholder Remedies' (Law Com. No. 246, 1997), para. 16.1.

Brenda Hannigan, Company Law (4. Bas1, Oxford 2013), 418.

2006 İngiliz Şirketler Kanunu; madde 260 vd.

2006 İngiliz Şirketler Kanunu; madde 263.

742006 İngiliz Şirketler Kanunu; madde 260

(1) This Chapter applies to proceedings in England and Wales or Northern Ireland by a member of a company-(a) in respect of a cause of action vested in the company, and (b) seeking relief on behalf of the company. This is referred to in this Chapter as a "derivative claim". (2) A derivative claim may only be brought - (a) under this Chapter, or (b) in pursuance of an order of the court in proceedings under section 994 (proceedings for protection of members against unfair prejudice). (3) A derivative claim under this Chapter may be brought only in respect of a cause of action arising from an actual or proposed act or omission involving negligence, default, breach of duty or breach of trust by a director of the company. The cause of action may be against the director or another person (or both). (4) It is immaterial whether the cause of action arose before or after the person seeking to bring or continue the derivative claim became a member of the company..."
} 
dahil olmak üzere kasti veya ihmalden kaynaklanan bir eylem gerekçesiyle şirketin lehine ve menfaati için davaya şirket adına devam edilmesini talep etmek amaciyla mahkemeye türev dava açabiliri ${ }^{75}$. Türev dava, yöneticilere karşı açılabileceği gibi yönetici olamamalarına rağmen davranış ve ya işlemleriyle şirkete zarar veren yönetici olmayan kişilere karşı da açılabiliir ${ }^{76}$.

İngiliz Şirketler Kanununun 260 (3) maddesinde tanımlandığı üzere, davacı, ihmal de dahil olmak üzere yöneticilerin görevlerini ihlali halinde de mahkemeye

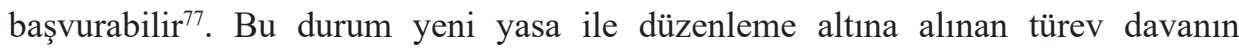
kapsamının olarak ihmalden doğan eylemleri içermeyen eski davadan daha geniş olduğunu göstermektedir ${ }^{78}$. Davacının bu tali iddiayı mahkemeye taşıyabilmesi ve davaya şirket adına devam etme izni alabilmesi için şirket yöneticisinin yapmış olduğu şirkete zarar veren eylemden dolayı herhangi bir menfaati olmasına gerek yoktur. Ayrıca, yeni haliyle davacının iddia ettiği eylemlerin varlı̆̆ını kanıtlamasına ilk aşamada gerek yoktur ${ }^{79}$.

\subsection{Davanın Tarafları}

\subsection{Davacı}

2006 Şirketler Kanununun 260. maddesine göre türev dava açmak için mahkemeye başvuran davacının şirketin pay sahiplerinden biri olması gerekmektedir ${ }^{80}$. İ̧̧K 260 (5) (c) hükmünde pay sahibi sıfatının şirket hisselerinden bir kısmını hukuken devralmış olan kişileri de kapsayacağ ifade edilmiştir ${ }^{81}$. Buradan hareketle örneğin payları miras yoluyla yahut cebri icra ile iktisap eden kişilerin de davacı olabilecekleri söylenebilir.

Bir pay sahibi, şirkette paya sahip olmadan önceki dönemde meydana gelen olaylar gerekçesiyle de türev dava açabilir ${ }^{82}$. Davaya konu olan fiilin veya işlemin davaya devam etmek isteyen kimsenin pay sahibi olmasından önce veya sonra ortaya çıkmasının bir önemi yoktur. Zira burada korunan davacı pay sahibinin değil şirketin menfaati olduğu için, pay sahibinin pay sahipliğinden önceki eylem ve işlemler gerekçesiyle de dava açabilmesi kanun koyucu tarafindan kabul edilmiştir. Ancak

\footnotetext{
2006 İngiliz Şirketler Kanunu; madde 260(3).

76 Joffe (n 65) 35.

77 Deirdre Ahern, 'Directors' Duties: Broadening the Focus beyond Content to Examine the Accountability Spectrum' (2011) 33 Dublin University Law Journal 116-118; Bourne (n 63) 230

78 Mujih (n 65) 76.

79 Joffe (n 65) 35.

80 Reisberg, 'Funding Derivative Actions: A Re-Examination of Costs and Fees as Incentives to Commence Litigation' (n 57) 348 .

812006 İngiliz Şirketler Kanunu; madde 260(5)(c).

82 Seaton v Grant (1867), LR 2, Ch. App. 459; Stephen Griffin, 'Alternative Shareholder Remedies Following Corporate Mismanagement - Which Remedy to Pursue?' (2017) 281 Company Law Newsletter 1, 2.
} 
Birch v Sullivan ${ }^{83}$ davasında da belirtildiği gibi davacı talebini mahkemeye taşıdığı zaman şirkette pay sahipliği sıfatını kazanmış olmalıdır ${ }^{84}$.

Pay sahibi burada mevcut olan bir dolaylı zararı gerekçesiyle dava açmakta ve bu davayı şirket adına ve hesabına açmaktadır. Bu husus türev dava ile pay sahiplerinin doğrudan zararlarının tazmini amacıyla açmış oldukları sorumluluk davasını ayıran en önemli husustur. Yalnız unutulmamalıdır ki, davacı pay sahibinin başvurusu üzerine mahkeme tarafından pay sahibine davaya şirket adına devam edilebilme için izni verilmelidir ${ }^{85}$. Ek olarak tekrar belirtilmelidir ki, bu hakka başvurabilmek için pay sahiplerinin belli bir oranda paya sahip olmalarına gerek yoktur ${ }^{86}$. Her bir pay sahibi oy oranına bakılmaksızın bu hakkı kullanabilir.

Burada akla gelen sorulardan biri şirkette payların çoğunluğuna sahip olan ve dolayısıyla şirketin kontrolünü elinde bulunduran pay sahiplerinin mahkemeye türev dava açabilme hakkına haiz olup olmadıklarıdır. Hannigan, ${ }^{87}$ İşK 260. maddesinde şirketin her bir pay sahibinin türev dava açmak için mahkemeye başvurabileceğini belirtilse bile, bu ifadeden yalnızca azınlık pay sahiplerinin algılanması gerektiğine dikkat çekmektedir. Teknik olarak, şirketi kontrol eden ve çoğunluğu temsil eden pay oranına sahip olan pay sahiplerinin madde 260 kapsamında mahkemeye başvurmalarının önünde herhangi bir engel bulunmamaktadır. Ancak, anılan pay sahiplerinin bu davayı mahkemeye taşıması türev davanın düzenlenme amacına uygun değildir. Çünkü çoğunluğu elinde bulunduran pay sahibi zaten şirket üzerindeki kontrol gücü nedeniyle böyle bir başvuruya gerek duymadan sorunlarını çözebilecektir ${ }^{88}$. Ancak eklemek gerekir ki, Cinematic Finance Ltd v Ryder ${ }^{89}$ davasında mahkeme, çoğunluğu temsil eden pay oranına sahip olan pay sahiplerinin çok istisnai durumlarda türev dava açabilmesinin mümkün olabileceğini karara bağlamıştır. Nitekim her durumda payların çoğunluğunu elinde bulunduran kişilerin aynı zamanda şirketin kontrolüne de sahip olduğu söylenemez.

\subsection{Davalı}

2006 tarihli İŞK 260 (3) maddesi uyarınca türev dava bir yöneticiye karşı veya şirkete zarar veren üçüncü bir kişiye karşı yahut her ikisine karşı birlikte açılabilir. İŞK 260/5 uyarınca, yönetici ifadesinden görevi sona eren eski bir yönetici veya

\footnotetext{
83 Birch v Sullivan [1957], 1 WLR 1247.

84 Reisberg, 'Funding Derivative Actions: A Re-Examination of Costs and Fees as Incentives to Commence Litigation' (n 57) 348.

${ }^{85} \mathrm{Bu}$ nedenle "derivative action" kanuni yolu aslında iki aşamadan oluşmaktadır. Bu aşamalar ilerleyen bölümlerde incelenecektir.

86 Hannigan (n 87) 422.

87 ibid 423.

88 ibid 423.

89 Cinematic Finance Ltd v Ryder and others [2010], EWHC 3387 (Ch).
} 
yönetici sıfatı bulunmamakla birlikte perde gerisinde ortaklığ1 yöneten kişiler diğer bir tabirle gölge yöneticiler de anlaşılabilir. Örneğin eski bir yönetici, şirkette yönetimde olduğu sırada şirketin imkanlarını kullanarak haksız bir menfaat elde etmişse bu eski yönetici aleyhine türev dava açılabilir. Ayrıca, 2006 Şirketler Kanunu dışarıdan bir kişiye karşı türev dava açılmasına da izin vermektedir. Burada amaç yöneticinin görevini ihlal etmesine yardımcı olarak şirkete zarar veren bir kişiye karşı da dava açılabilmesidir ${ }^{90}$. Dahası, bu kişi şirketin mallarını elinde bulundurduğunda yöneticinin eylemleri hakkında bilgisi olan herhangi biri olabilir ${ }^{91}$.

\subsection{Davanın Usulü}

2006 İŞK öncesinde yani türev dava yasalaşmadan önceki dönemde, ortak hukuk hükümlerine göre, türev dava açmak için mahkemeye başvuran pay sahibinin, "azınlık pay sahibine karşı yapılan hileli eylemi" "92 ve "hukuka aykırı hareket eden kişilerin şirketin kontrolünü elinde bulundurduğunu"93 ispat etmesi bekleniyordu. Hukuk Komisyonu'nun raporunda da belirttiği gibi, bu prosedür oldukça belirsiz ve karmaşıktı ve bu dava hakkının kullanım alanını daraltıyordu. ${ }^{94} \mathrm{Bu}$ nedenle, hukuka aykırı hareket eden kişilerin yönetim kurulunu kontrol ediyor olduğu gerekçesiyle dava açılabilmesi oldukça zordu. İşte bu zorluklar dolayısıyla Hukuk Komisyonu, şirket adına davaya devam edilmesine karar verme yetkisinin şirket yönetim kurulları yerine mahkemelere verilmesini tavsiye edilmiştir ${ }^{95}$. Bunu yapmak, hem azınlık pay sahibini ağır ispat yükünden kurtaracak hem de mahkemeye davaya şirket adına devam edilmesine karar verilebilme yetkisi vererek aynı zamanda şirketleri de gereksiz davalardan koruyacaktı.

2006 tarihli İşK madde $261^{\prime}$ de $^{96}$ yer alan türev davanın bu iki aşaması aşağıdaki bölümde analiz edilecektir.

\subsection{Davanın İlk Așaması}

2006 tarihli İŞK ile türev davanın yargılama sürecinin ilk aşaması olarak davaya şirketin katılımıyla devam edebilmek için mahkemeden izin alma zorunluluğu getirilmiş̧ir ${ }^{97}$. Burada amaç mahkeme tarafından davaya edilebilmesi için izin verilmesi halinde davanın davacı pay sahibinin yerine şirket adına ve hesabına

\footnotetext{
Hannigan (n 87) 426.

Law Commission, ‘Shareholder Remedies' (Law Com. No. 246, 1997), para. 6.35; Hannigan (n 87) 423.

'fraud on the minority'

'wrongdoer control'

Law Commission, ‘Shareholder Remedies’' (Law Com. No. 246, 1997) para. 1.4.

ibid para. 6.73 .

962006 İngiliz Şirketler Kanunu; madde 261.

${ }_{97}$ Andrew Keay and Joan Loughrey, 'Derivative Proceedings in a Brave New World for Company Management and Shareholders' (2010) 3 Journal of Business Law 151, 153.
} 
devam etmesidir ${ }^{98}$. Yönetim kurulu ve genel kurul, genellikle çoğunluk payı elinde bulunduran pay sahipleri tarafindan kontrol edildiğinden dava açma veya davaya katılma yetkisinin şirkete bırakıldığı hallerde azınlık pay sahiplerinin mağdur olduğu görülmüştürr9. Bu iki aşamalı dava usulüyle ayrıca davacı pay sahibinin bu dava ile şirket için gereksiz harcamaya veya zaman kaybına neden olup olmayacağının mahkeme tarafindan takdir edilmesi ve davaya buna göre devam edilmesi amaçlanmaktayd $1^{100}$. Mahkeme bu aşamada sadece davacı pay sahibinin sunduğu delilleri dikkate alır ve incelemeyi dosya üzerinden delilleri değerlendirerek yapar. Davacının sunduğu deliller dışında ilk aşamada mahkeme şirketten veya davalıdan yeni delil talep edemez ${ }^{101}$.

Bir türev davada, birinci aşamayı geçip davaya şirketin katılımıyla devam edebilmek için davacının bu davayı açmakta menfaati olduğunu ve davanın devam etmesi halinde mahkemeyi kanıtlarıyla ikna edebileceğini göstermesi gerekir. Eğer mahkeme başvurunun ve başvuran tarafindan sunulan delillerin davaya devam edebilmek için yeterli olmadığına kanaat getirirse davayı reddeder ${ }^{102}$.

Mahkeme ayrıca, 2006 Şirketler Kanununun 261. maddesi uyarınca dava ile ilgili uygun gördüğü herhangi bir kararı verebilir. Davacı pay sahibinin davaya devam izni almak için mahkemeye kanıt sunması gerekmektedir ${ }^{103}$. Eğer mahkeme ilk aşamada başvuruyu reddetmezse mahkeme davacıdan yahut şirketten yeni kanıt talep edebilir ${ }^{104}$.

Örnek mahkeme kararlarına bakıldığında Cullen Investment Ltd v Brown $n^{105}$ davasında mahkeme ilk bakışta bunun haklı bir başvuru olduğuna hükmederek davaya şirket adına devam edilmesine izin verdi. Bunun aksine, Bridge v Daley106 davasında mahkeme, davacı pay sahibi tarafından ileri sürülen delillerin yeterli olmadığına kanaat getirip, davaya devam etme izni vermeyi reddederek, yargılama giderlerinin davacı pay sahibi tarafindan ödenmesine karar verdi ${ }^{107}$. Anılan davada, davacı yöneticilerin yapmış oldukları hukuka aykırı işlem ve eylemler nedeniyle şirket adına yöneticilere karşı davaya devam etme izni talep ediyordu.

\footnotetext{
98 Dignam ve Lowry (n 54) 190.

99 Paul von Nessen, S.H. Goo and Chee Keong Low, 'The statutory derivative action: now showing near you' (2008) 7 Journal of Business Law 627, 648.

100 Andrew Keay, 'Applications to continue derivative proceedings on behalf of companies and the hypothetical director test' (2015) 34 (4) Civil Justice Quarterly 346, 348.

101 Iesini v Westrip Holdings Ltd [2009], EWHC 2526 (Ch).

102 Keay, (n 101) 348.

103 Mujih (n 65) 76; Joffe (n 65) 80.

1042006 İngiliz Şirketler Kanunu; madde 261/3; Dignam ve Lowry (n 54) 190.

105 Cullen Investment Ltd v Brown [2015], EWHC 473 (Ch).

106 Bridge v Daley [2015], EWHC 2121 (Ch).

107 David Milman, 'Shareholder Law: Recent Developments in Practice' (2015) 378 Company Law Newsletter 1, 3.
} 
Mahkeme, davacı tarafından ileri sürülen iddiaların şirket adına bir türev dava açılmasını haklı kılmadığını, hatta davacının iddialarının İŞK madde $994^{108}$ kapsamında açılacak olan bir haksız ayrımcılık davası ile değerlendirilmesinin daha doğru olacağını ifade etmiştir ${ }^{109}$.

\subsection{Davanın İkinci Aşaması}

İzin prosedürünün ikinci aşaması, mahkemenin davaya devam etmek için izin verilip verilmeyeceğini belirleyeceği bir duruşmayı içerir. Mahkemenin bu noktada geniş bir takdir yetkisi vardır. 2006 Şirketler Kanunu 261(4) ${ }^{110}$ maddesine göre, mahkeme için üç seçenek vardır: davacının mahkemenin uygun olduğunu düşündüğü koşullarla davaya devam etmesine izin vermek; davaya devam edilmesine izin vermeyi reddetmek, ya da yargılamaların ertelenmesi ve mahkemenin uygun gördügü şekilde davanın esasına ilişkin karar vermesidir. Bu mesela mahkemenin şirket genel kurulunun toplanmasına karar vermesi şeklinde olabilir ${ }^{111}$.

Mahkeme, davacının türev davayı mahkemeye getirirken iyi niyetle hareket edip etmediğini değerlendirmelidir ${ }^{112}$. Eğer davacı tarafından davalının ihmal ettiği belirtilen görevi İngiliz Şirketler Kanununun 172. maddesine dayanan bir eylemse yani yöneticilerin temel görevine (şirketin başarısı için çalışmak) ${ }^{113}$ göre hareket etmediği iddia ediliyorsa mahkeme izin vermekten kaçınmalıdır ${ }^{114}$. Çünkü yöneticilerin şirketin başarısını arttırmak için çalışma görevi ancak şirkete karşıdır ve şirket tarafından açılacak bir sorumluluk davasına konu edilebilir. İkinci olarak belirtilmesi gereken husus ise eğer davanın gerekçesi olan, şikâyete konu eylem şirket tarafından sonradan onaylanmışsa ${ }^{115}$ veya aslında şirket tarafından yetkilendirilerek yapılmışsa mahkeme davaya devam etme izni vermekten kaçınmalıdır ${ }^{116}$.

\footnotetext{
2006 İngiliz Şirketler Kanunu; madde 994.

109 Milman (n 108) 3.

1102006 İngiliz Şirketler Kanunu; madde 261/4.

111 Joffe (n 65) 46.

112 Griffin (n 83) 2 .

113 Promote the success of the company (şirketin başarısını arttırmak için çalışmak); 2006 İngiliz Şirketler Kanunu; madde 172.

114 Paul L. Davies ve Sarah Worthington, Gower \& Davies Principles of Modern Company Law (9. Bas1, Sweet \& Maxwell 2012), 656.

115 If the cause of the case arises from an existing or proposed act or omission which has been ratified or authorized by the company.

1162006 İngiliz Şirketler Kanunu; madde 263(2).
} 


\subsection{Davaya İlişkin Analiz Edilmesi Gereken Hususlar}

\subsection{Yargllama Giderleri}

Davacı azınlık pay sahibi, şirketten şirket adına hareket etmek için harcadığı yargilama giderlerinin kendisine geri ödenmesini talep edebilir ${ }^{117}$. Ancak bu talepte bulunabilmesi için davacı pay sahibinin şirketin çıkarlarına uygun olarak iyi niyetle hareket etmesi gerekmektedir. ${ }^{118}$

Wallersteiner v Moir (No 2) 119 davasında da mahkeme tarafindan, davacı azınlık pay sahibinin yargılama giderleri ile ilgili şirketten tazminat talep etme hakkı olduğu vurgulanmıştır ${ }^{120}$. Bu davada verilen karar nedeniyle yargılama giderlerinin şirket tarafindan ödenmesi talebi "Wallersteiner order" yani Wallersteiner emiri olarak da adlandırılmaktadır. Ancak Walton J, Smith v Croft ${ }^{121}$ davasında mahkeme farklı bir bakış açısı sunmuştur. Mahkeme, davacı azınlık pay sahibinin yapmış olduğu yargılama giderlerinin kendisine ödenmesini şirketten talep edebilmesi için türev davanın açılmasının gerekli olduğunun kanıtlanması gerektiğine karar vermiştir. Buna göre, mahkeme tarafından davacının giderlerinin şirket tarafından kendisine geri ödenmesine karar verilebilmesinin çok kolay olmayacağı ortadadır. Kaldı ki bu kararın davanın erken bir aşamasında verilmesi daha da güç olacaktır. Zira, mahkemenin davacının açmış olduğu türev davanın gerekliliğine karar verebilmesi için sunulan tüm delilleri göz önünde bulundurarak esasa ilişkin inceleme yapması gerekmektedir ${ }^{122}$.

Smith v Croft karar1 ${ }^{123}$, yargılama giderlerinin şirket tarafından ödenmesi talebinin reddedilmesi nedeniyle birçok eleştiri ald. Wallersteiner emiriyle ${ }^{124}$ uyuşmayan ve giderlerin şirket tarafindan ödenmesi için daha kısıtlayıcı olan Smith v Croft kararının, Faybird Group Ltd v Greenwood125 davasinda mahkeme tarafindan desteklenmediği belirtilmelidir. Bu konuda en çok eleştirilen, mahkemenin erken aşamada davaya ilişkin net bir fikir sahibi olamayacağı ve dolayısıyla nihayetinde masrafların yine davacı tarafından ödenmesinin bu hakkın kullanımını sınırlayacağı hususuydu. Ayrıca başka bir husus da şudur ki, mahkeme yargılama giderlerinin şirket tarafından karşılanmasına karar verdikten sonra dava reddedilirse şirketin mağduriyeti söz konusu olacaktır. Bu nedenle, öğretide önerildiği gibi, temel ilke,

\footnotetext{
117 Boyle ve Birds ve diğ erleri (n 36) 676.

118 Quigxiu Bu, 'The indemnity order in a derivative action' (2006) 27(1) Company Law, 4.

119 Wallersteiner v Moir [1974], 1 WLR 991.

120 Jennifer Payne, 'Sections 459-461 Companies Act 1985 in Flux: The Future of Shareholder Protection` (2005) 64 The Cambridge Law Journal 647, 658.

121 Smith v Croft (No.2) [1988], Ch. 114.

122 Payne (n 121) 658.

123 Smith v Croft (No.2) [1988], Ch. 114.

124 Wallersteiner v Moir [1975], QB 373.

125 Faybird Group Ltd v Greenwood [1986], BCLC 319327.
} 
azınlık pay sahibinin yargılama giderlerini şirkete rücu edebilmesi olmalıdır. Ancak, alternatif olarak, davanın sonucunun pay sahipleri için de faydalı olması durumunda, işlemlerin sonunda yargılama giderlerinin ortak ödenmesine karar verilebilir ${ }^{126}$.

\subsection{Ortaya Çıkan Hukuki Sorunlar}

2006 İŞK ile kanuni olarak düzenlenen türev dava hakkı, ortak hukuk kuralları çerçevesinde başvurulan eski haline göre özellikle ispat bakımından daha esnek ve daha az kısıtlayıcı olsa da hala bazı sorunlar içermektedir ${ }^{127}$. Şirketin ayrı tüzel kişiliği bulunması sebebiyle şirket adına iş ve işlem yapma hakkı da şirkete aittir ve bu hakkı şirket organları aracılığıyla kullanır. Bu nedenle, davacının türev dayaya şirket adına devam edebilmek için mahkemeden izin alınması prosedürü her ne kadar anlaşılabilir olsa da bu hakkın kullanımını pay sahipleri açısından öngörülmeyecek derecede belirsiz hale getirmektedir ${ }^{128}$. Nitekim 2006 tarihli İşK davacı pay sahibine bir türev davaya şirket adına devam etme izni alabilmesi için uzun bir prosedür sunmaktadır. Hukuk Komisyonu'nun da belirttiği gibi, bu adımlar pratik değildir ve süreci yavaşlatmaktadır, bu da hakkı etkisiz ve kullanılamaz hale getirmektedir.

Söylemek gerekir ki, bir pay sahibinin türev dava açmak için mahkemeye başvurması, yargılama giderleri ve davanın karmaşık prosedürü düşünüldüğünde davacıya ağır yükümlülükler getirmektedir. Dava sonunda verilecek olan kararın yalnız şirket adına ve hesabına bir çözüm olması ve başvuran pay sahibini dolaylı olarak etkilemesi de ayrıca hakkın kullanımı için pay sahipleri bakımından bir çekince oluşturmaktadır.

Görülmektedir ki 2006 tarihli İŞK'nın 11. bölümünde düzenlenen yasal prosedürün uygulamaya konulması azınlık hissedarların korunma alanını genişletmek adına birçok iyileştirme içermesine rağmen bazı endişeleri de barındırmaktadır ${ }^{129}$. Mahkemenin takdir yetkisi davanın açılması ve devamı için oldukça geniştir ve şu ana kadar İngiliz hukukundaki örneklerine bakıldığında hâkimlerin davaya şirket adına devam edilmesi tercihini çok nadir yaptığı görülmektedir. Bunun yanında azınlık pay sahiplerine bahşedilen ve 2006 İşK 994. maddesinde düzenlenen "haksız ayrımcılık davası"130 pay sahipleri için daha esnek ve kapsayıc çözümler sunmaktadır. Bu davaya ilişkin bilgilere geçmeden önce bir sonraki bölümde Türk hukukunda yönetim kurulu ve yöneticiler aleyhine açılacak olan sorumluluk davalarının ne şekilde düzenlendiği incelenecektir.

\footnotetext{
26 Reisberg dava giderleri hususunda açık bir düzenleme olmaması nedeniyle hala azınlık pay sahiplerinin bu hakkı kullanmaktan kaçındığını ve giderlerin şirket tarafından da katlanılması için bir düzenleme yapılması ve böylece pay sahiplerinin türev dava açmak için mahkemeye başvurmaya teşvik edilmesi gerektiğini savunmaktadır. Bknz Reisberg, 'Funding Derivative Actions: A Re-Examination of Costs and Fees as Incentives to Commence Litigation' (n 57) 348.

127 Law Commission, 'Shareholder Remedies' (Law Com. No. 246, 1997), para. 6-4.

128 Alistair Alcock, John Birds ve Steve Gale, Companies Act 2006 (1. Bas1, Jordan Publishing 2009).

129 İngiliz hukukunda azınlık pay sahiplerine verilen bu iki hakkın farkları ilerleyen bölümlerde incelenecektir.

1302006 İngiliz Şirketler Kanunu; madde 994.
} 


\subsection{Türk Hukukunda Sorumluluk Davası}

Türk Ticaret Kanunu (TTK) madde $553^{131}$ uyarınca anonim şirket yönetim kurulu üyeleri kanun ve esas sözleşmeden doğan yükümlülüklerini kusurları ile ihlal etmeleri halinde doğan zararlar sebebiyle şirkete, pay sahiplerine ve şirket alacaklılarına karşı sorumludurlar. Şirketin uğramış olduğu zararın tazmini için TTK madde 555 ve 556 'da düzenlenen şartlarda şirketin yanı sıra pay sahipleri ve şirketin iflası halinde şirket alacaklıları da sorumluluk davası açabilir. Şirketin uğradığı zararın tazminini, şirket ve pay oranına bakılmaksızın her bir pay sahibi isteyebilirr ${ }^{132}$.

İngiliz hukukunun aksine, Türk hukukunda TTK madde 555 ile tazminatın şirkete ödenmesi koşuluyla şirketin uğradığı zararlardan dolayı şirketin yanında pay sahiplerine de doğrudan dava açma hakkı verilmiştir. İngiliz hukukunda uygulanan iki aşamalı sistem bizim hukukumuzda uygulanmamaktadır. Burada pay sahibinin talep edeceği zarar doğrudan değil dolaylı yani yansıyan bir zarardır. Yani burada söz konusu olan şirketin uğradığı zararın pay sahibine pay sahipliği dolayısıyla yansıması neticesinde ortaya çıkan zarardır ${ }^{133}$. Kanun koyucu burada anonim şirket malvarlığında yönetim kurulu üyelerinin eylemleri dolayısıyla meydana gelen azalmaların, pay sahiplerinin pay değerlerinde de bir azalma meydana getireceğini göz önünde bulundurarak pay sahiplerine de bu hakkı tanımıştır ${ }^{134}$. Dolaylı zarara örnek olarak, şirkete ait makinaların yönetim kurulu üyelerinin şahsi işlerinde kullanmas $1,{ }^{135}$ mal girişi olmamasına rağmen şirketin bono vererek borçlandırılmas $1,{ }^{136}$ şirket defterlerinin usulüne uygun hazırlanmaması yahut şirket adına çekilen kredinin şahsi işlerde kullanılması verilebilir. Yine, yönetim kurulu üyelerinin anonim şirket malvarlığında azalmaya sebebiyet vermeleri halinde meydana gelen zarar şirket açısından doğrudan zarar olarak kabul edilmeliyken, pay sahipleri ve alacaklılar için dolaylı zarar kabul edilmelidir ${ }^{137}$.

Yönetim kurulu üyeleri aleyhine açılacak olan sorumluluk davalarında yeni kanun kapsamında en tartışmalı konulardan biri şirket adına dava açılabilmesi için genel kurul kararının gerekli olup olmadığıdır. Kanun koyucu, mülga 6762 sayılı TTK'da madde 341 kapsamında genel kurul kararıla şirket yönetim kurulu üyelerinin aleyhine dava açılabileceğini düzenlemişti. Ancak şu an yürürlükte olan 6102 sayılı TTK'da böyle bir düzenleme bulunmamaktadır. Öğretide de bu konu tartışmalı olup

\footnotetext{
131 Türk Ticaret Kanunu; madde 553. Companies Act 2006 (1. Bas1, Jordan Publishing 2009).

132 Yargitay 11 HD, 6410/14405, 09.06.2016.

133 Haluk Tandoğan, 3. Şahsın Zararının Tazmini [Mesuliyet] (1. Bası, Ankara 1963) 98; Ahmet Kılıçoğlu, Borçlar Hukuku Genel Hükümleri (20. Bas1, Seçkin 2016) 287.

134 Poroy, Tekinalp ve Çamoglu (n 44) 604.

135 Yargitay $11 \mathrm{HD}, 642 / 1273,22.02 .2012$.

136 Yargitay $11 \mathrm{HD}, 10318 / 9813,13.05 .2013$.

137 Mehmet Çelebi Can, 'Pay Sahiplerinin veya Alacaklıların Doğrudan Zararlarının Tazmini Amacıyla İkame Edilen Sorumluluk Davalarında TTK m.1534'ün Etkisi' (2017) 21 Galatasaray Üniversitesi Hukuk Fakültesi Dergisi (GÜHFD) 4 , $10-12$.
} 
bazı yazarlarca ${ }^{138}$ şirket adına dava açabilmek için hala genel kurul kararına ihtiyaç duyulduğu savunulmaktadır. Buna karşlık, yeni kanunda genel kurul kararından doğrudan bahsedilmemiş olmasının bilinçli bir tercih olduğunu ve dolayısıyla şirket adına dava açabilmek için genel kurul kararına ihtiyaç olmadığını savunan yazarlar da vardır ${ }^{139}$. Yargıtay ise anonim şirket tarafindan yönetim kurulu aleyhine açılacak olan sorumluluk davalarında genel kurul kararının gerekli olduğunu içtihat etmiştir ${ }^{140}$.

Bir çözüm yolu olarak genel kurul kararı yerine İngiliz hukukunda olduğu gibi davanın pay sahiplerinin başvurusu üzerine mahkemece şirket adına açılması düşünülebilir. Ancak zaten Türk hukukunda pay sahipleri tarafindan da bizzat sorumluluk davası açılabilmektedir. Mahkemeye başvurup dava açma izni almalarına gerek yoktur. Yalnız belirtmek gerekir ki, mahkemenin pay sahibine türev davaya devam etme izni vermesi neticesinde davacı bizzat şirket olacağı için yani dava şirket adına ve hesabına açılmış olacağı için yönetim kurulu üyelerine karşı kusurlarının ve şirkete verdikleri zararın ispatı daha kolay olacaktır ${ }^{141}$. Nitekim

6762 sayılı mülga TTK'nın 336 ve 339. maddelerine göre yönetim kurulu üyelerinin kusurlu oldukları kabul ediliyordu ve onlardan kusursuzluklarını ispat etmeleri bekleniyordu. Bir başka deyişle yönetim kurulu üyelerinin kusurlu olduklarına ilişkin bir karine mevcuttu ve bu karineye göre davacıların yönetim kurulu üyelerinin kusurlarını ispat etme yükümlükleri yoktu ${ }^{142}$. Ancak 6102 sayılı yeni TTK madde 553 hükmünde böyle bir karineye yer verilmediği için kusurun varlığının ispat yükümlülügünün davacıya ait olduğunu anlıyoruz ${ }^{143}$. Ancak ispat için kullanılabilecek olan şirket belgeleri yönetim kurulunun kontrolünde olacağından yönetim kurulunun sorumluluğunun ispatı zor olabilir. İngiliz hukuk sistemine göre açılmış olan türev dava her ne kadar pay sahibince mahkemeye taşınsa da zaten şirket adına olacağından ispat bakımından kolaylık olacağ düşünülebilir. Nitekim, 2006 İngiliz Şirketler Kanunu öncesinde ortak hukuk hükümlerine göre, türev dava açmak için mahkemeye başvuran pay sahibinin ispat yükünün hafifletilmesi amacıyla Hukuk Komisyonu, şirket adına davaya devam edilmesine karar verme yetkisinin şirket yönetim kurulları yerine mahkemelere verilmesini tavsiye etmişti ${ }^{144}$. Ayrıca böyle bir uygulamanın şirketleri pay sahiplerince açılan anlamsız ve sayıca

138 Abuzer Kendigelen, Yeni Türk Ticaret Kanunu: Değişiklikler, Yenilikler ve İlk Tespitler (3. Bası, On İki Levha 2016), 308; Erdoğan Moroğlu, 6102 Sayılı Türk Ticaret Kanunu (Başlangıç Hükümleri, Ticari İşletme, Ticaret Şirketleri, Klymetli Evrak ve Son Hükümler) Değerlendirme ve Öneriler (7. Bas1, On İki Levha 2012) 323; Oruç Hami Şener, Teorik ve Uygulamall Ortaklıklar Hukuku (3. Bası, Seçkin 2017) 423.

139 Poroy, Tekinalp ve Çamoglu (n 44) 601; Mehmet Helvac1, 'Yönetim Kurulu Üyelerinin Hukuki Sorumluluğunda Farklılaştırılmış Teselsül’ (2013) Prof. Dr. Oğuz İmregün'e Saygı Sempozyumu, 2 Galatasaray Üniversitesi Hukuk Fakültesi Dergisi (GÜHFD) 78.

140 Yargitay 11 HD, 5386/14890, 30.09.2014; Yargitay 11 HD, 7487/6166, 02.06.2016.

141 Hayri Domaniç, Anonim Şirketler (1. Bası, Eğitim 1978), 292.

142 Pulaşlı (n 265) 715 vd.

143 Himmet Koç, Anonim Şirket Yönetim Kurulu Üyelerinin Farklılaştırılmış Teselsül İlkesi Uyarınca Sorumluluklarına Genel Bir Bakış, (2020) Necmettin Erbakan Üniversitesi Hukuk Fakültesi Dergisi (NEÜHFD) 1, 3.

144 Law Commission, 'Shareholder Remedies’ (Law Com. No. 246, 1997) para. 6.73. 
yoğun dava yükünden kurtaracağı düşünülüyordu. Ancak son durumda İŞK madde 260 kapsamında pay sahibince türev dava iddiasıyla mahkemeye başvurulduğunda davanın ilk aşamasının geçilip mahkemeden davaya devam edilmesi için izin alınabilmesi için de başvuran pay sahibinin davaya devam etmekteki menfaati ispat etmesi gerekmektedir. Düşünüldüğünde henüz davaya devam etme izni alınmamışken yönetim kurulu üyelerinin ya da diğer davalıların şirkete verdikleri kusurun ve zararın pay sahibi tarafından ispatı daha zor olacaktır. Kaldı ki yukarıda da ifade edildiği gibi mahkeme ilk aşamada davacının gösterdiği delillerle bağlıdır. Mahkeme ikinci aşamaya gelene kadar davalıdan veya şirkette ek delil talep edemez ${ }^{145}$.

Dahası, İngiliz hukukunda pay sahiplerini türev dava açmaktan alıkoyan en önemli sebeplerden birisi birinci aşamada davanın mahkemece reddi halinde yargılama giderlerinin pay sahibi tarafından bizzat ödenmesinin gerekliliği iken; Türk hukukunda TTK 'da madde 555(2) uyarınca pay sahibinin açtığı davayı hukuki ve maddi sebepler haklı gösterdiği takdirde, mahkeme, dava giderleriyle avukatlık ücretini, bu giderler davalıya yükletilemediği hâllerde, davacı pay sahibiyle şirket arasında, hakkaniyete göre paylaştırılmasına karar verebilir ${ }^{146}$. Burada amaç dolaylı zararın varlığında açılan sorumluluk davalarında pay sahibinin şirket hesabına bu davayı açmaya teşvik edilmesidir. Nitekim davanın kazanılması halinde tazminat hakkı şirkete ait olacağından, hakkaniyet uyarınca davanın kaybı durumunda da dava için yapılan masrafların şirket ve pay sahibi arasında paylaştırılması öngörülmüştür ${ }^{147}$.

Burada ayrıca türev davaların şirket yöneticilerinin yanında 3. kişilere karşı da açılmasının mümkün olduğunu, ${ }^{148}$ buna karşı1lı Türk hukukunda sadece TTK madde 553 kapsamında sayılmış olan kurucular, yönetim kurulu üyeleri, yöneticiler ${ }^{149}$ ve tasfiye memurlarına karşı sorumluluk davasının açılabileceğini belirtmek gerekiyor. İngiltere'de açılmış olan türev dava örneklerine bakıldığında görülecektir ki bu davalarda da davalı genellikle yöneticilerdir. Ancak bu durum 3. kişilere karşı da 2006 İşK madde 260 kapsamında türev dava açılabilmesinin mümkün olduğu gerçeğini değiştirmez. Dolayısıyla azınlık pay sahiplerinin hukuka aykırı eylem veya

\footnotetext{
145 Dignam ve Lowry (n 54) 190.

1466102 Sayılı Türk Ticaret Kanunu Gerekçesi (<http://www.basbakanlik.gov.tr/docs/kkgm/kanuntasarilari/TURK\%20 TICARET/madde\%20gerekc e.doc> Erişim tarihi 30 Kasım 2020.

147 Ancak burada Yargıtay'ın her zaman yargılama giderlerini şirket ve davacı pay sahibi arasında paylaştırmadığını eklemek gerekir. Nitekim bazı kararlarında Yargıtay dolaylı zarardan kaynaklanan sorumluluk davasında yargılama giderlerinin sadece davacı pay sahibi tarafından ödenmesine şirketle paylaştırılmamasına karar vermiştir. Bknz Moroğlu (n 139) 346; Ayrıca bakınız, Yargitay 11 HD, 5587/10164, 23.05.2016; Yargitay 11 HD, 16826/7902, 04.11.2014. Yargitay bir nevi HMK m.326'de yer alan davada giderler haksız çıkan tarafa yükletilir prensibini esas almaktadır. Hakan Pekcanıtez, Oğuz Atalay ve Muhammet Özekes, Medeni Usul Hukuku (14. Bas1, Yetkin 2013), 153.

1482006 İngiliz Şirketler Kanunu; madde 260(3).

149 Yanlı, burada yönetici ifadesiyle kastedilenin sadece özel olarak belirlenmiş yahut görevlendirilmiş kişiler olmadığını bu kapsama şirketin temel faaliyetlerine yön veren kişilerin de dahil olabileceğini ifade etmektedir. Bknz Veliye Yanll, 'Şirkete Verilen Zarar Sebebiyle Sorumluluk Bağlamında "Yönetici” Kavramı ve Genel Kurul Kararı Gerekliliği Sorunu' (2019) 141 Terazi Hukuk Dergisi 51, 46-57, 48.
} 
işlemleri ile şirkete zarar veren çoğunluk paya sahip hissedarlar aleyhine türev dava açabilmeleri mümkündür.

Sonuç olarak söylenebilir ki; İngiliz hukukunda İŞK madde 260 ve devamında yer alan türev dava ile Türk hukukunda TTK madde 555 'te düzenlenen yönetim kurulu üyeleri aleyhine açılabilecek sorumluluk davası kıyaslandığında aralarında birçok farklıklar olduğu görülecektir. İngiliz hukuk sisteminde yer alan iki aşamalı türev dava her ne kadar yöneticilere karşı açılan gereksiz davaların sayısını azaltsa da kendi içerisinde sorunlar barındıran ve hem masrafları dolayısıyla hem de prosedürü dolayısıyla pek tercih edilmeyen bir davadır.

\subsubsection{Haksız Ayrımcılık Davası (Unfair Prejudice Petition)}

\subsection{Dava Hakkının Ortaya Çıkışı}

Ortak hukukta görülebileceği gibi, Foss v Harbottle ${ }^{150}$ davasında ortaya çıkan kural pay sahiplerinin haklarını daraltmıştır ${ }^{151}$. Zira bu dava neticesinde bir şirket ayrı bir tüzel kişilik olarak kabul edildi, yani üyelerinden (pay sahipleri ve yöneticilerden) ayrı yasal haklar ve sorumluluklarla donatılmış bir 'tüzel kişi' haline geldi ${ }^{152}$. İşte bu kural nedeniyle ortaya çıkan sorunların üstesinden gelebilmek için 1948 tarihli İngiliz Şirketler Kanununun 210. maddesinde 153 "oppression remedy" adında yeni bir düzenleme oluşturulmuştur. Azınlık pay sahiplerine tanınan bu hak, aynı zamanda pay sahiplerinin şirket yönetiminden dışlanma yahut şirketin kötü yönetimi gibi sebeplerle başvurabilecekleri tek yol olan ve pay sahibine şirketin iflasını isteyebilme hakkı tanıyan tasfiye davasına ${ }^{154}$ alternatif olarak düzenlenen ilk haktır.

İŞK 1948'in 210.maddesinde ${ }^{155}$ düzenlenen “oppression remedy”, 2006 tarihli İŞK madde 994'te düzenlenen ve İngiliz hukukunda azınlık pay sahiplerine rahatlama sağlayan temel haklardan biri olan haksız ayrımcılık davasına başvurmanın temeli olarak görülmektedir. Nitekim, baskı anlamına gelen "oppression” ifadesi Scottish Co-operative Wholesale Society v Meyer ${ }^{156}$ davasında 'külfetli, sert ve yanlış' olarak yorumlanmış ve belirsiz bulunmuştur. Bu konuda açıklık sağlamak için "unfair prejudice" teriminin kullanılması önerilmiş ve terim 1980 tarihli Şirketler Kanunu 75. maddede ${ }^{157}$ yer bulmuştur. Bu yeni düzenlemenin 1948 tarihli yasaya göre daha

\footnotetext{
150 Foss v Harbottle [1843], 67 ER 189.

151 Dignam, Hicks and Goo (n 28) 225.

152 Boyle ve Birds ve diğerleri (n 36) 58.

153 Companies Act 1948; Sarah Worthington ve Len Sealy, Sealy's Cases and Materials in Company Law (9. Bas1, Oxford University Press 2016), 647.

1541986 İngiliz İflas Yasas1; madde 122.

1551948 İngiliz Şirketler Kanunu; madde 210.

156 Scottish Co-op. Wholesale Society v Meyer [1959], A.C. 324

1571980 İngiliz Şirketler Kanunu; madde 75.
} 
kapsayıcı olduğu ifade edilmiştir ${ }^{158}$. 1980 tarihli düzenleme, 1985 tarihli Şirketler Kanunu madde 459' da ${ }^{159}$ da küçük değişiklikler yapılarak korunmuştur. Ve nihayet haksız ayrımcılık davası hem başvuru sebepleri hem de mahkemenin dava sonucu verebileceği kararlar dolasıyla pay sahipleri için en önemli dava haklarından biri olarak 2006 İŞK madde 994 'te ${ }^{160}$ düzenlenmiştir.

\subsection{Dava Hakkının Genel Analizi}

İngiliz hukukunda bir azınlık pay sahibi, şirkette çoğunluk payı elinde bulunduran pay sahiplerince yahut yöneticilerce baskı altına alındığında şirketin adil ve hakkaniyete dayanarak tasfiyesi için "tasfiye davası" açabilir'161. Ancak, özellikle şirket kârlı bir şirket ise, azınlık pay sahibi bu tür bir işlem yapmak konusunda isteksiz olabilir"162. İşte bu gibi durumlarda pay sahipleri alternatif bir çözüm olarak "haksız ayrımcılık davası" iddiasıyla mahkemeye başvurabilirler. Bu hak, İŞK 2006'nın 994. maddesinde düzenlenmiştir ${ }^{163}$.

2006 İŞK 994. madde uyarınca, şirketin her bir pay sahibi, şirket işlerinin tamamının yahut bir kısmının, kasten veya ihmal yoluyla kendi menfaatlerine zarar verecek şekilde yürütülmesi halinde mahkemeye başvurarak haksız ayrımcılık davası açabilir ${ }^{164}$.

$\mathrm{Bu}$ dava yoluna başvuru oranı, borsada işlem görmeyen küçük ve orta ölçekli şirketlerde daha yüksektir. Zira halka açık bir şirkette, bir pay sahibinin diğer pay sahipleriyle veya şirket yönetimiyle ilgili bir sorunu varsa yahut şirkette haksız bir ayrımcılık hissediyorsa, hisselerini piyasada satabilir ve sorununu çözebilir. Tabi ki her

158 John McMullen, 'Minority Protection and Section 75 of the Companies Act 1980' (1983) 42 The Cambridge Law Journal 204, 205.

1591985 İngiliz Şirketler Kanunu; madde 459.

1602006 İngiliz Şirketler Kanunu; madde 994

161 Bu hak 1986 tarihli İngiliz İflas Yasasının 122. Bölümünde düzenlenen "winding up the company on the basis that it is just and equitable" hakkıdır.

162 Charlie Newington-Bridges, 'A Practical Guide to Unfair Prejudice Petitions and their Interaction with Derivative Claims' (Stjohnschambers.co.uk, 2016) <https://www.stjohnschambers.co.uk/wp-content/uploads/2018/07/Unfair-prejudicepetitions-and-derivative-actions.pdf> Erişim Tarihi 06 Ocak 2021.

1632006 İngiliz Şirketler Kanunu; madde 994

"Petition by company member

(1) A member of a company may apply to the court by petition for an order under this Part on the ground-

(a) that the company's affairs are being or have been conducted in a manner that is unfairly prejudicial to the interests of members generally or of some part of its members (including at least himself), or

(b) that an actual or proposed act or omission of the company (including an act or omission on its behalf) is or would be so prejudicial.

(1A) For the purposes of subsection (1)(a), a removal of the company's auditor from office -

(a) on grounds of divergence of opinions on accounting treatments or audit procedures, or

(b) on any other improper grounds, shall be treated as being unfairly prejudicial to the interests of some part of the company's members.]

(2) The provisions of this Part apply to a person who is not a member of a company but to whom shares in the company have been transferred or transmitted by operation of law as they apply to a member of a company.

(3) In this section, and so far as applicable for the purposes of this section in the other provisions of this Part, "company" means -

(a) a company within the meaning of this Act..."

1642006 İngiliz Şirketler Kanunu; madde 994. 
zaman ve her şartta halka açık şirketlerde paylar satılmak istendiğinde kolaylıkla satı̧̧ yapılabilir ve sorunlar çözülebilir demek doğru olmayacaktır. Nitekim İngiliz kanun koyucu da bu durumu gözeterek halka açık şirketlerin pay sahipleri için 2006 Şirketler Kanunu'nda bu hakka başvuru noktasında herhangi bir kısıtlama getirmemiştir. Buna rağmen, bu şirketlerde "haksız ayrımcılık davası" açma yoluna başvurulması yahut açıldıktan sonra başarılı olunması oldukça nadirdir. Bunun yanında çoğunluk payı elinde bulunduran pay sahipleri için de haksız ayrımcılık davası açma noktasında kanuni bir engel bulunmamaktadır. Ancak yine onlar açısından da bu davayı açma oranı ve dava sonunda mahkeme tarafindan olumlu karar verilmesi ihtimali oldukça düşüktür ${ }^{165}$.

\subsection{Davanın Tarafları}

2006 İ̧̧K madde 994 şirketteki her bir pay sahibinin başvuruda bulunduğu sırada pay sahibi olması şartıyla "haksız ayrımcılık davası" açabileceğini içermektedirr"166.

İSKK 994. ${ }^{167}$ madde uyarınca üyelik kavramının iki anlamı daha vardır. Bunlardan birincisi, payların devredildiği ancak pay siciline işlenmediği hallerde de pay sahipliği geçerli kabul edilir. Payların devredilmesi ifadesinden, hukuka ve prosedüre uygun olarak söz konusu payların devralan kişiye geçirilmesi örneğin; pay senetlerinin teslimi anlaşılmalıdır ${ }^{168}$. Sadece taraflar arasında pay devri anlaşması olması yeterli değildir ${ }^{169}$. İkinci anlamı ise hisselerin hukuken aktarıldığ 1 fakat henüz pay sahiplerinin isimlerinin sicile girmediği hallerde de üyelik geçerli kabul edilir ve davacı olunabilir ${ }^{170}$. "Hukuken aktarılan" terimi, yasal unvanın geçtiği yasal bir prosedür gerektirir. Örneğin, bir üyenin ölümü üzerine hisseleri davacıya miras bırakabilir veya davacı, kişisel temsilci veya iflas halinde yediemin olabilirr ${ }^{171}$. Ayrıca madde 994 kapsamında şirketin eski pay sahipleri de dava açabilir. Nitekim eski bir pay sahibi, pay sahipliği sona erdikten sonra, pay sahibi olduğu sırada aleyhinde haksız bir eylemin gerçekleştirildiğini öğrenirse, o kişi davacı olabilir ${ }^{172}$.

Haksız ayrımcılık davasının daha iyi anlaşılabilmesi için bu davaya başvuru koşullarının analiz edilmesi gerekmektedir. İşK madde 994 uyarınca davaya konu olan eylem, mahkemeye başvuran pay sahibinin, pay sahipliğinden kaynaklanan menfaatlerine haksiz yere zarar vermelidir ${ }^{173}$.

\footnotetext{
165 Re Ravenhart Service (Holdings) Ltd [2004], 2 BCLC 376.

166 Robert A.G. Monks, 'Modern Company Law for a Competitive Economy: The Strategic Framework' (2000) 8 Corporate Governance: An International Review 16, 18.

1672006 İngiliz Şirketler Kanunu; madde 994.

168 Bknz Re a Company (No. 003160 of 1986) [1986], BCLC 391

169 Re a Company (No 003160 of 1986) [1986], BCLC 391; Re Quickdome Ltd [1988], BCLC 370.

1702006 İngiliz Şirketler Kanunu; madde 994/2.

171 Re McCarthy Surfacing Ltd; Hecquet v McCarthy [2006], EWHC 832 (Ch).

172 Davies ve Worthington (n 115) 682.

1732006 İngiliz Şirketler Kanunu; madde 994/1; Sealy ve Sarah (n 154) 691
} 
Ayrıca davacının şikayetçi olduğu davranış şirket üyesinin ayrımcı tutumunun bir sonucu olmalıdır ${ }^{174}$. Bu husus yargıç Jonathan Parker J tarafından Re Blackwood $H_{o d g}{ }^{175}$ davasında ifade edilmiştir. Buna göre, davacı yalnızca yöneticilerin görevlerini ihlal etmelerinden kaynaklı olarak haksızlığa uğradığını değil aynı zamanda söz konusu ihlallerin yöneticilerin ayrımcılığa varan haksız davranışları neticesinde olduğunu göstermelidir ${ }^{176}$.

İŞK madde 994'de haksız ayrımcı davranıştan ne anlaşılması gerektiğine ilişkin bir açıklama olmamasına rağmen, içtihatlarda bazı açıklamalar bulmak mümkündür ${ }^{177}$. İçtihatlara göre kıstas, makul bir kişi tarafından bu davranış neticesinde azınlık hissedarlarının çıkarlarının haksız yere ayrımcı davranışlarla ihlal edildiğinin değerlendirip değerlendirilemeyeceğidir ${ }^{178}$. Davacının, şirketteki çoğunluk paya sahip olan pay sahiplerinin kötü niyetle hareket ettiklerini veya kendisine haksız muamele etme niyetinde olduklarını kanıtlaması gerekmemektedir. O'Neill v Phillips ${ }^{179}$ davasında, yargıç Lord Hoffmann tarafından haksız davranışın tespitinde "adil” davranış kriterinin aranması gerektiği ifade edildi. Ayrıca "geleneksel ve genel” olarak şirket içinde yapılmaması gereken bir davranışın davacıya karşı davalılarca yapılmış olması halinde de yine haksız ayrımcılık davası açılabilmesinin mümkün olduğu belirtildi.

O’Neill v Phillips davası İngiliz hukukunda azınlık pay sahiplerinin korunması için oldukça önem arzetmektedir. Anılan davada, davalı Phillips, şirkette çoğunluk hisseye sahip, şirket işleri ve binalardan sorumlu bir şirketin yöneticisiydi. O’Neill isimli bir çalışana, kârın \%50'si ile birlikte şirkette \%25 hisse sözü verdi. Phillips ayrıca O’Neill'i şirkete yönetici olarak da atadı. Phillips'in yöneticilikten ayrılmasından sonra, O’Neill şirkette tek ve fiili yönetici oldu. Ancak şirketin işleriyle ilgili sorun çıkmaya başladığında Phillips, O’Neill'i suçlayarak şirketin kontrolünü tekrar ele almak için kendini yönetici olarak atadı. Ayrıca daha önce yaptıkları kar paylaşımı sözleşmesini kendi adına feshettiğini söyleyerek O’Neill'e söz verdiği daha fazla hisseyi verme vaadini gerçekleştirmeyeceğini söyledi. O’Neill, kâr paylaşımı anlaşmasının sona ermesi ve kendisine şirkette daha fazla pay sağlayacak olan düzenlemenin tek taraflı olarak feshedilmesi gerekçesiyle Phillips'e dava açtı. Her iki çözüm yolu için de başvurdu; ${ }^{180}$ adil ve eşitlikçi bir şekilde şirketin tasfiyesi ${ }^{181}$ veya haksız ayrımcılık gerekçesiyle paylarının satılarak bedelinin kendisine ödenmesi ${ }^{182}$.

\footnotetext{
2006 İngiliz Şirketler Kanunu; madde 994; Re BSB Holdings Ltd (No 2) [1996], 1 BCLC 155; Irvine v Irvine (No 1) [2007], 1 BCLC 349; Re Southern Counties Fresh Foods Ltd [2008], EWHC 2810 (Ch).

175 Re Blackwood Hodge [1997], 2 BCLC 650, 673.

176 Re Sunrise Radio, Kohli v Lit [2010], 1 BCLC 367.

177 Dignam ve Lowry (n 54) 237.

178 Newington-Bridges (n 163) 1.

179 O’Neill v Phillips [1999], 2 BCLC 1.

1802006 İngiliz Şirketler Kanunu; madde 994; Dignam ve Lowry (n 54) 239.

1811986 İngiliz İflas Yasası; madde 122.

182 Dignam ve Lowry (n 54) 239.
} 
Lordlar Kamarası tarafindan yapılan yargılama sonucunda, taraflar arasındaki anlaşmanın resmi bir anlaşma olmadığı ve dolayısıyla davacıda hisse payının artırılacağ1 yönünde meşru bir beklentinin bulunamayacağ1 gerekçesiyle O'Neill'in haksız olduğuna karar verildi. Lord Hoffmann, burada İşK madde 994'ün uygulama alanında bulunan bir sorun olduğunu düşündüğü için şirket pay sahipleri arasında dürüstlük kuralına aykırı olarak ortaya çıkan uyuşmazlıklar dolayısıyla haksız ayrımcılık davasının açılabileceğini belirtti. $\mathrm{Bu}$ dava sonucunda, azınlığa yapılan haksızlığın, davalının hukuka aykırı eylemleri yanında, kendi menfaati için dürüstlük kuralına aykırı olacak şekilde yapmış olduğu eylemler dolayısıyla da ortaya çıkabileceği kabul edildi. Grace v Biagiol $^{183}$ davasında mahkemenin verdiği karar O’Neill davasına paraleldi ve Lord Hoffmann'ın görüşünü doğrulad $1^{184}$.

2006 tarihli İşK madde 994 uyarınca açılan bir haksız ayrımcılık davasında davacının şikâyet ettiği davranışın, kurumsal bir işlem veya eylemden kaynaklanan 'şirket işleri' ile ilgili olması gerekmektedir ${ }^{185}$. "Şirket işleri" ifadesinden ne anlaşılması gerektiğine ilişkin yasada herhangi bir açıklama mevcut değildir. $\mathrm{Bu}$ hususta, içtihat hukukuna baktığımızda Re Legal Costs Negotiators Ltd ${ }^{186}$ davasında verilen karar dikkat çekmektedir. Anılan davada, mahkeme, şirket pay sahipleri arasındaki bir uyuşmazlıktan dolayı dördüncü pay sahibinin paylarının diğer üç hissedara satılması talebini reddetti ve bu davaya konu olacak haksız eylemin şirket tarafından yapılmasi ${ }^{187}$ gerektiğine örneğin, şikâyete konu işlem veya eylemin yönetim kurulu veya şirket genel kurulu kararıyla haksız olarak ortaya çıkması gerektiğine hükmetti ${ }^{188}$.

Özetlemek gerekirse, davacı şikâyetine konu olan işlem veya eylemin hem haksız olduğuna hem de ayrımcı davranışlarla yapıldığına dair mahkemeyi ikna etmelidir ${ }^{189}$. Mahkeme de yargılama süresince dava ile ilgili unsurları değerlendirirken objektif olmalı ve madde 994 çerçevesinde bir karar verebilmek için haksız davranışın kaynağının şirketi kontrol edenlerin baskıcı ve ayrımcı tutumuna dayandığı konusunda ikna olmalıdir ${ }^{190}$.

\footnotetext{
$\overline{183}$ Grace v Biagiol [2006], 2 BCLC 70.

184 French, Mayson ve Ryan (n 52) 572.

185 Hannigan (n 87) 490.

186 Re Legal Costs Negotiators Ltd [1999], 2 BCLC 171.

${ }^{187}$ Ayrıca burada not düşmek gerekir ki eğer şirket yönetiminde bulunan ve şirketin kontrolünü elinde bulunduran kişi tarafından davacıya karşı bir haksız ve baskıcı eylem varsa "unfair prejudice petition" hakkının uygulanabilirliği düşünülebilir; Dignam ve Lowry (n 54) 488.

188 Dignam ve Lowry (n 54) 228.

189 Nicholas v Soundcraft Electronics Ltd [1993] BCLC 360, Sikorski v Sikorski [2012], EWHC 1613 (Ch).

190 Re RA Noble \& Sons Clothing Ltd [1983], BCLC 273, Fisher v Cadman [2006], 1 BCLC 499, Wilson v Jaymarke Estates Ltd [2007], UKHL 29.
} 


\subsection{Davaya Konu Olabilecek Uyuşmazlıklar ve İngiliz İçtihat Hukukundan Örnekler}

İngiltere'de, mahkemeler, bazen yapılan yargılamanın sonunda 2006 İŞK madde 994 kapsamında karar vermeyi reddetmiş olsalar bile uygulayıcı ve akademisyenlerin ilgili maddeyi daha iyi anlamalarına yardımcı olmak için ayrıntılı analizler yapmış ve gerekçeli kararlarıyla literatüre katkı sağlamışlardır.

Şirket yönetiminden dışlanma, şirketin hatalı ve pay sahibine zarar verebilecek şekilde yönetimi, yöneticilerin temsil yetkisini kötüye kullanması, şirketin işleyişine ilişkin hususlarda pay sahibine danışmama veya bilgi verememe, ana sözleşmenin veya pay sahipleri arasındaki sözleşmelerin ihlali, kâr payı ödenmemesi gibi hususlar İ̧̧K madde 994 kapsamında açılacak olan haksız ayrımcılık davasının gerekçelerine örnek olarak sayılabilir. Davacıların haksız ayrımcılık davasına en çok başvurduğu haller aşağıda incelenecektir.

\subsection{1 Şirket Yönetiminden Dışlanma}

Haksız davranışın en önemli örneklerinden biri, özellikle küçük ölçekli şirketlerde pay sahibinin yönetimden dışlanması veya yönetim kurulundan haksız yere çıkarılmasıdır ${ }^{191}$.

Yönetimden dışlanma iddialarının, "haksız ayrımcılık davası" kapsamında haksız eylem olarak değerlendirilerek hüküm verilmesi olasılığı halka açık şirketlerde veya üyelerin çoğunluğunun yabancı yatırımcı olduğu şirketlerde daha düşüktür ${ }^{192}$. Çünkü yabanc1 yatırımciların beklentileri genellikle yatırımlarından daha fazla gelir elde etmektir. Ancak, küçük ölçekli ve halka kapalı şirketlerde, üyeler arasında resmiyetten ziyade karşılıklı güven ve anlayışa dayalı kişisel bir ilişki görmek mümkündür. Bu tür şirketlerde pay sahipleri çoğunlukla yönetici pozisyonunda da olurlar.

Davacı eğer şirket yönetiminden dışlandığını iddia ediyorsa, ortada yönetimden dışlanmaya dayalı haksız bir davranışın olup olmadığına karar verebilmek için her dava kendi koşullarına göre değerlendirilir ve mahkeme genellikle davacının olaydaki meşru beklentilerini ${ }^{193}$ araştırır. Re Tottenham Hotspur plc. ${ }^{194}$ davasına konu olan olayda Terry Venables şirketteki görevinden alınınca kendisine haksızlık yapıldığı iddiasıyla madde 994 kapsamında mahkemeye başvurdu. Terry Venables, halka açı bir şirket olan Spurs futbol kulübünün CEO'suydu. Mahkeme bu davayı Terry Venables'in şirkette yönetici olarak devam etmek için meşru bir beklentisi olamayacağı gerekçesiyle reddetti ${ }^{195}$.

\footnotetext{
191 Bourne (n 63) 234.

192 Re Posgate \& Denby (Agencies) Ltd [1986], 2 BCC 99.

193 Legitimate expectation

194 Re Tottenham Hotspur Plc [1994], 1 BCLC 655.

195 Dignam ve Lowry (n 54) 241.
} 
Bunun aksine, Re RA Noble \& Sons (Clothing) Ltd ${ }^{196}$ davasinda, pay sahibinin şirketten dışlanması sebebiyle mahkeme davacıyı haklı kabul ederek madde 994 kapsamında bir hüküm vermiştir. Yönetimden dışlanmanın haksız davranış kabul edilerek davacının haklı bulunduğu ve mahkemenin madde 994 kapsamında bir çözüm yolunda karar kıldığ 1 davalardan biri de Re London School of Electronics Ltd. ${ }^{197}$ davasıdır ${ }^{198}$. Anılan davada, Mr Lytton bir eğitim şirketinde \%25 paya sahip bir pay sahibi ve aynı zamanda yönetici olarak şirket yönetiminden dışlandığını iddia etmiştir. Davacı, şirket yönetiminden dışlanmasının gerekçesinin diğer yöneticilerin kendi aleyhindeki haksız ve ayrımcı davranışları olduğunu savunmuştur. Diğer yöneticiler ise Lytton'ın, şirket aracilığıyla, öğrencileri kendi kurduğu eğitim kurumuna yönlendirdiğini ve bunun kabul edilemez bir durum olduğunu söylemişlerdir. Mahkeme ilgili kanun hükmünde davacının davayı açarken kusuruz olması gerektiğine (temiz ellerle gelmesi gerektiğine) dair bir ibare olmadığını dolayısıyla davacinın iddiasını kanitlaması halinde kusuru olsa bile bu madde kapsamında lehine hüküm verilebileceğini belirtmiş ve davacının hisselerinin diğer hissedarlar veya şirketin kendisi tarafından uygun bir bedelle satın alınarak davacının şirketten çıkmasına karar vermiştir ${ }^{199}$.

Örneklerden de anlaşılacağı üzere, yönetimden ve şirket işlerinden dışlanma gerekçesiyle açılan davalarda başarılı bir sonuca ulaşma oranı küçük ölçekli şirketlerde hatta özellikle İngiltere'de "quasi-partnership" olarak adlandırılan şirketlerde daha yüksektir. Bu şirketler, pay sahipleri arasındaki kişisel ilişkilerin özellikle güven ilişkisinin ve karşılıklı anlayışın ön planda olduğu şirketlerdir. Genellikle bu tür şirketlerde pay sahipleri aynı zamanda yönetici pozisyonunda da bulunurlar. Belirtmek gerekir ki, mahkemenin değerlendirmesi her dava için farklı olacaktır. Anılan türden bir şirkette pay sahibi olan davacının şirket yönetiminden dışlandığı iddiasıyla açtığı dava her zaman davacı lehine sonuçlanır denilemez ${ }^{200}$.

\subsection{Kötü Yönetim}

İŞK madde 994 kapsamında değerlendirilebilecek haksız davranışın en önemli örneklerinden biri şirketin kötü yönetilmesi halidir ${ }^{201}$. Yönetim kurulu şirketin yönetimini gerektiği şekilde yerine getirmezse ve sermaye kaybına veya şirketin zarar etmesine neden olursa ve bunun neticesinde pay sahipleri de zarar görmüşse burada haksız davranışın varlığından söz edilebilir ${ }^{202}$.

\footnotetext{
196 Re RA Noble \& Sons Clothing Ltd [1983], BCLC 273.

197 Re London School of Electronics Ltd [1986], Ch. 211.

198 Dava tarihinde geçerli olan kanun itibariyle dava 1980 tarihli Şirketler Kanununun 75. maddesine dayanarak açılmıştır.

199 Bourne (n 63) 235.

200 Bourne (n 63) 234.

201 Hannigan (n 87) 427.

202 Robin Hollington, Hollington on Shareholders' Rights (8. Bas1, Sweet \& Maxwell 2016).
} 
Burada belirtilmeli ki bazen davacı, şirkette kötü yönetim olduğunu kanıtlamak için kanıt sunsa bile, mahkeme, şirket yöneticilerinin kararlarının davacıya karşı haksız ayrımcılık içerdiği konusunda karar vermekte isteksiz olabilmektedir ${ }^{203}$. Mahkemenin isteksizliği iki gerekçeye dayanmaktadır ${ }^{204}$.

Bunlardan ilki, yönetim kurulunun şikâyet konusu olayda iyi niyetle ve şirketin faydasına olacağını düşünerek birkararalmış olmasıdır. İkincisi ise şirketler hukukunun doğasına uygun olarak, şirket yönetim kurulu tarafından alınan kararların bir soruna yol açması her zaman mümkündür ${ }^{205}$. Nitekim "business judgement rule" yani bizim ifade ettiğimiz şekliyle iş adamı kararı ilkesi uyarınca, yönetim kurulu üyeleri, üyelik sıfatlarına dayanan ve ortaklığın olağan iş ve faaliyetlerini gerçekleştirmekten kaynaklanan seçimlerinin sonuçlarından dolayı sorumlu tutulamazlar ve bu faaliyetlerden dolayı yargılanamazlar ${ }^{206}$. Bu nedenle, şirketin işleyişinde aksaklıklara neden olmuş olsa bile yöneticilerin yapmış olduğu işlemler hakimler tarafindan madde 994 kapsamında haksız davranış olarak değerlendirmeyebilir ${ }^{207}$. Ancak takdir hakk1 yine mahkemelerdedir.

Şirketin kötü yönetildiği iddiasıyla açılan davalarda sorun çoğunlukla pay sahipleri ve yöneticiler arasındaki ticari politika farklılıklarından kaynaklanmaktadır. Mahkemenin şirketin kötü yönetimi gerekçesiyle madde 994 kapsamında davacı lehine bir karar verebilmesi için ortada yöneticilerin özen yükümlülüklerinin dişına çıktıklarını veya görevlerini ihlal ettiklerini gösteren kanıtlar bulunmalıdır ${ }^{208}$. Genel olarak hangi faktörlerin şirketin kötü yönetiminin göstergesi olacağını içeren bir düzenleme yahut bir mahkeme kararı yoktur. Mahkeme, Re Elgindata Ltd ${ }^{209}$ davasinda, şirket yöneticileri şirkette payların çoğunluğuna sahip ve şirketi yönetirken hatalar yapmış kişiler olmasına rağmen, şirketin yönetim kurulu tarafından verilen kararların haksız ayrımcılık davasında başarılı bir sonuca ulaşmak için gerekçe olamayacağını belirtti $^{210}$.

Bununla birlikte İŞK madde $994^{211}$ kapsamında verilen mahkeme kararlarından biri olan Re Macro (Ipswich) $L t d^{212}$ davasında, yöneticilerin şirketi kötü yönetimi

\footnotetext{
203 Kershaw (n 31) 274.

204 Joffe (n 65) 290.

205 Re Elgindata Ltd [1991], BCLC 959.

206 Stephen Radin, The Business Judgement Rule - Fiduciary Duties of Corporate Directors (5. Bas1, Aspen Law and Business 1998).

207 Oak Investment Partners XII, Limited Partnership v Boughtwood [2009], 1 BCLC 453; Joffe (n 65) 291.

208 Stuart Sime ve Margot Taylor, Company Law in Practice (12. Bas1, Oxford University Press 2017), 188.

209 Re Elgindata Ltd [1991], BCLC 959.

210 Dignam ve Lowry (n 54) 244; Sealy ve Sarah (n 154) 729.

2112006 İngiliz Şirketler Kanunu; madde 994.

212 Bknz Re Macro (Ipswich) Ltd [1994], 2 BCLC 354; Anılan davada ilişkili iki şirkette de müdür olan şirketin yöneticilerinden birinin uzun yıllar şirketteki görevlerini ihmal etmesi sonucu, çalışanlar, şirketin emlakçıları tarafindan kazanılan komisyonları çalarak şirket varlıklarını kötüye kullanmışlardır.
} 
nedeniyle bir şirketin büyük bir mali kayba uğraması neticesinde, mahkeme, azınlık pay sahibi olan davacının hisselerinin uygun bir bedel karş1lı̆̆ (bu bedel belirlenirken şirketin yöneticilerin ihlalleri neticesi sebep oldukları zarar da göz önünde bulundurulmak suretiyle $)^{213}$ payların çoğunluğuna sahip hissedarlar veya tek başına bir yönetici tarafından satın alınmasına karar vermiştiir ${ }^{214}$.

Özet olarak söylenebilir ki, yöneticilerin şirkette yol açtıkları sorunlar ve görevlerini ihlal ederek şirketi kötü yönetmeleri yani şirketi zarara uğratmaları halinde mahkemenin İŞK madde 994 kapsamında karar verebilmesi için basit bir görev ihlali yerine şirkete daha ciddi zararlar vermiş bir kötü yönetim olmalıdır ${ }^{215}$. Bunun yanında eğer ki davacının başvurulabileceği başka bir yol varsa, yöneticilerin görevden alınmasını sağlamak gibi, davacı sorununu çözmek için öncelikle o yolu tercih etmelidir ${ }^{216}$.

\subsection{Yöneticilerin Görevlerini Kötüye Kullanması}

Küçük ölçekli bir şirketin dava konusu edildiği Re London School of Electronics $L t d^{217}$ davasında, aynı zamanda şirkette payların çoğunluğuna da sahip olan yöneticiler, şirketin varlıklarını kendi sahip oldukları başka bir şirkete kullandırmak suretiyle görevlerini kötüye kullanmış ve davacı azınlık pay sahibinin başvurusu üzerine mahkeme 994. madde kapsamında davacı lehine karar vermiştir. Yine bu madde kapsamında davacının lehine karar verilen davalardan olan Gerrard $v$ Koby $y^{218}$ davasında, davacı tarafından yöneticilerin şirket fırsatlarını kendi hesaplarına kullanarak görevlerini kötüye kullandıkları iddia edilmiştir.

Özetlemek gerekirse, bir yöneticinin güvene dayalı görevlerini kötüye kullanması İŞK madde 994 kapsamında her zaman haksız davranış teşkil etmez. Ancak, böyle bir iddia söz konusuysa, mahkeme bu durumu dikkatle değerlendirmelidir. Nitekim bazen özellikle küçük ölçekli şirketlerde ve yöneticilerin aynı zamanda şirkette payların çoğunluğuna sahip hissedarlar olduğu durumlarda haksız ayrımcılık davas $1^{219}$ hükümleri kapsamında karar verilebilir ${ }^{220}$.

\subsection{Dava Sonucu Mahkemenin Alabileceği Kararlar}

2006 tarihli Şirketler Kanununun 996 (1) maddesi uyarınca, bir pay sahibinin "haksız ayrımcılık davası" hükümleri kapsamında, şirkette haksız ve baskıcı

\footnotetext{
213 French, Mayson ve Ryan (n 52) 585.

214 Dignam ve Lowry (n 54) 243.

215 Kershaw (n 31) 280.

216 Hannigan (n 87) 427.

217 Re London School of Electronics Ltd [1986], Ch 211.

218 Re Baumler (UK) Ltd Gerrard v Koby and another [2004], All ER (D) 139.

2192006 İngiliz Şirketler Kanunu; madde 994.

220 Cook v Deeks [1916], 1 AC 554; Joffe (n 65) 306.
} 
davranışlara maruz kaldığı gerekçesiyle dava açması halinde, mahkeme pay sahibinin sorununu çözecek bir hüküm vermelidir ${ }^{221}$.

İŞK madde 996 (2) uyarınca, mahkeme; şirketten şikayet edilen davranıştan kaçınılmasını ve bir daha aynı davranışın tekrar edilmemesini; ${ }^{222}$ davacının talep ettiği işlemin şirket yöneticilerince yapılmasını; davacı tarafından şirket adına mahkemeye talepte bulunulmasına izin verilmesini; ${ }^{223}$ ve en çok başvurulan çare olarak davacı pay sahibinin hisselerinin şirket ${ }^{224}$ ve ya diğer pay sahipleri tarafından satın alınarak bedelinin davacıya ödenmesini isteyebilir ${ }^{225}$. Özellikle İŞK madde 994 kapsamında en çok verilen karar olan davacı pay sahibinin paylarının satılarak şirketten ayrılması çözüm yolu bu hakka bir sonlandırma(exit) hakkı niteliği kazandırmıştır ${ }^{226}$.

Aşağıda İngiliz hukukunda azınlık pay sahiplerine bahşedilmiş önemli dava haklarından biri olan tasfiye davası incelenecektir.

\subsubsection{Tasfiye Davası (Winding Up Order)}

1986 yılında yürürlüğe giren İngiliz İflas Yasası madde 122/1 uyarınca ${ }^{227}$ göre azınlık pay sahipleri, adil bir gerekçeyle şirketin feshini talep etmek için mahkemeye başvurma hakkına sahiptirler. Bu yol daha çok hissedarlar arasında güven kaybının olduğu şirketlerdeki pay sahipleri için faydalı olabilir. Uygulamada, bir şirketin adil gerekçelerle feshedilmesinin tipik olduğu üç önemli durum söz konusudur. İlk olarak, genellikle küçük ortaklıklarda ortaya çıkan pay sahibinin yönetimden dışlanması durumudur ${ }^{228}$. Nitekim azınlık hissedarının çoğunluk paya sahip hissedarların etkisiyle şirketteki yöneticilik pozisyonundan çıkarılması, şirketteki tüm menfaatlerini kaybetmesine sebep olmaktadır. Bu hakkın kullanımına verilebilecek en önemli örneklerinden biri Ebrahimi v Westbourne Galleries Ltd. ${ }^{229}$ davasıdır.

İngiliz şirketler hukukunda Ebrahimi v Westbourne Galleries Ltd davasının önemi büyüktür. Bu davada, bir hissedarın "quasi-partnership" olarak kurulmuş olan bir şirketin yönetiminden haksız bir şekilde çıkarılması söz konusudur ${ }^{230}$. Bu davayı önemli kılan nokta ise davada Lord Wilberforce başkanlığındaki mahkeme tarafindan,

\footnotetext{
2212006 İngiliz Şirketler Kanunu; madde 996/1.

2222006 İngiliz Şirketler Kanunu; madde 996/2.

2232006 İngiliz Şirketler Kanunu; madde 996/2; Karar örneği için bknz O’Neill v Philips [1999], 1 WLR 1092.

224 Davacının hisselerinin şirket tarafından satın alınması durumunda, mahkeme şirket sermayesinin azaltılmasına karar verebilir.

2252006 İngiliz Şirketler Kanunu; madde 996/2.

226 Ruth Redmond-Cooper, 'Management Deficiencies and Judicial Intervention: A Comparative Analysis' (1988) 9(8) Company Lawyer, 169.

2271986 İngiliz İflas Yasası; madde 122.

228 Hollington (n 203) 38.

229 Ebrahimi v Westbourne Galleries Ltd [1973], AC 360.

230 Joffe (n 65) 284.
} 
İngiliz İflas Yasası'nın 122. maddesi ${ }^{231}$ kapsamında şirketin tasfiyesi istemiyle açılan bir davada, pay sahibinin şirket yönetiminden dışlanmasının adil gerekçe olarak kabul edilip edilemeyeceğinin gerekçeli olarak analiz edilmiş olmasıdır.

Anılan davada, Mr. Ebrahimi ve Mr Nazar “quasi partnership" şeklinde kurulmuş olan bir şirketin hissedarları ve aynı zamanda yöneticileriydi. İkisi de şirkette eşit hisse oranına sahiptiler. Bu iki ortağın şirket yönetimindeki pozisyonları ve güçleri aynı seviyedeydi ${ }^{232}$. Daha sonra 1958 'de işi daha profesyonel bir şekilde yürütmek için özel bir şirket kurmaya karar verdiler ve yine bu şirkette de ikisi birlikte yönetici oldular. Mr Nazar'ın oğlu da şirketin müdürü olarak atandıktan sonra onların babaoğul pay oranları ve şirketteki güçleri Mr Ebrahimi’ye göre daha fazla oldu. Nitekim genel kurulda oy çokluğuna sahip oldular. Kendisine karşı yapılan şirketten ve yönetimden dışlama eylemlerine daha fazla dayanamayan Mr Ebrahimi 1964 yılında, 1948 Şirketler Yasası'nın 210. maddesi uyarınca sorunun çözülmesi aksi halde şirketin tasfiye edilmesi için mahkemeye başvurdu. Bu davada mahkeme tarafından şirketin veya diğer hissedarların eylemleri neticesinde pay sahibine karşı adil hak ve yükümlülükler ve meşru beklentiler ihlal edilmişse şirketin tasfiye edilebileceği kabul edilmiştir ${ }^{233}$.

Lord Wilberforce'un dava hakkındaki görüşleri ve değerlendirmeleri azınlık pay sahiplerinin sahip olduğu yasal çözüm yollarını ve bunlar arasındaki ilişkiyi netleştirdi. Nitekim onun "adil hak ve yükümlülüklerin şirketin tasfiyesine varabilecek kadar ihlal edilmiş olması" noktasındaki yaklaşımını Re A Company ${ }^{234}$ davasında yargıç Hoffmann J da benimsedi.

Ebrahimi v Westbourne Galleries Ltd235 davasında Mr Ebrahimi şirkette kendisi üzerinde baskı olduğunu iddia ediyor ve bu durumu bertaraf edebilmek için 1948 tarihli İŞK madde $210^{236}$ kapsamında çözüm yolu arıyordu. Ayrıca alternatif olarak sorunun çözülememesi halinde şirketin tasfiyesini talep etmişti. Mahkeme yargılama sonunda 1948 tarihli İŞK madde 210 kapsamında ortada haksız bir davranış bulunmadığına hükmederek davayı reddetti. Ancak burada, Dignam'ın da belirttiği gibi mahkemenin Mr Ebrahimi'nin şikâyetlerini dikkate alarak, paylarının başka bir pay sahibine yahut şirketin kendisine devredilmesi suretiyle davacının ortaklıktan ayrılmasına karar vermesi daha uygun olacakt1237.

\footnotetext{
2311986 İngiliz Ifflas Yasas1; madde 122.

232 French, Mayson ve Ryan (n 52) 70.

233 Dignam, Hicks ve Goo (n 28) 442.

234 Re a Company (No. 00477 of 1986) [1986], BCLC 376.

235 Ebrahimi v Westbourne Galleries Ltd [1973], AC 360.

2361948 İngiliz Şirketler Kanunu; madde 210.

237 Dignam, Hicks ve Goo (n 28) 442.
} 
Bununla birlikte İngiliz hukukunda davanın koşullarına göre mahkemelerin çeşitli çözüm yolları ürettiği görülmüştür. Nitekim mahkeme bazen Loch v John Blackwood Ltd238 davasında olduğu gibi şirket üyeleri arasında güven kaybının davacı tarafından kanıtlandığı durumlarda şirketin feshine karar vermiştir. Re Yenidje Tobacco Co Ltd239 davasında olduğu gibi bazen de şirketin işlerinin yürütülmesinin durdurularak tabiri caizse şirketin kilitlenmesi gerekçesiyle açılan davalarda şirketin feshine karar vermiştir ${ }^{240}$.

Belirtmek gerekiyor ki, 1986 İngiliz İflas Yasasının 125 (2) maddesi ${ }^{241}$ uyarınca, eğer davacının şirketteki pozisyonunu düzeltmek için başvurabileceği başka bir yol varsa mahkeme tasfiyeden önce o çözüm yoluna gitmelidir. Yani şirketin tasfiyesi son çaredir ${ }^{242}$.

Uygulamaya bakıldığında, genellikle davalı tarafın davacının hisselerini almayı teklif ettiği ve dolayısıyla davacının İngiliz İflas Yasası 122 (1) maddesi² ${ }^{243}$ kapsamına girme girişiminin durdurulduğu görülecektir. Davacı şirketin tasfiyesinde 1srar ederse başka bir çözüm yolu olmadığını ve bu tüzel kişiliğin sona erdirilmesinin adil olduğunu ispat etmelidir ${ }^{244}$.

Burada iki hukuk yolu bakımından bir fark olduğu görülmektedir. Zira, davacı İflas Yasası madde 122 kapsamında mahkemeye başvurduğunda sonuca ulaşabilmek için şirketin tasfiyesinin adil ve hakkaniyete uygun olduğunu ispat etmek zorundayken; 2006 İŞK madde 994 uyarınca bir çözüme ulaşabilmesi için şirkette davalıların haksız davranışlarına maruz kaldığını ispat etmesi yeterlidir. Bu durum göstermektedir ki İŞK madde 994'te düzenlenen haksız ayrımcılık davası daha geniş bir kapsama ve dolayısıyla azınlık pay sahipleri için daha geniş bir korumaya sahiptir. Kaldı ki, gerekçeleri neredeyse aynı olan bu iki kanun yolundan tasfiyenin seçilmesi hem şirket için hem de şirketle alakalı diğer kişiler yani pay sahipleri, alacaklılar, kredi verenler için daha ağır sonuçlara yol açabilecektir. Davacı pay sahibinin sorunlarının çözümü için paylarının devralınarak şirketten ayrılması çoğu zaman yeterli olacaktır ${ }^{245}$.

\footnotetext{
38 Loch v John Blackwood Ltd [1924], AC 783.

239 Re Yenidje Tobacco Co. Ltd [1916], 2 Ch. 426.

240 Dignam ve Lowry (n 54) 242.

2411986 İngiliz İflas Yasası; madde 125.

242 Boyle ve Birds ve diğerleri (n 36) 675.

2431986 İngiliz İflas Yasası; madde 122.

244 Pettet ve diğerleri (n 38) 231.

245 Robin Hallington, 'Oppression of Minority Shareholders: Reflections on Blisset v Daniel' (2007) 19 Denning Law Journal 5, 8 .
} 


\section{Türk Ticaret Kanunu'nda Düzenlenen Haklı Sebeple Fesih Davası ve Bu Davanın İngiliz Hukukunda Azınlığa Tanınan Davalarla Karşılaştırılması}

\subsection{Haklı Sebeple Fesih Davasının İngiliz Hukukundaki Davalarla Karşılaştırılması}

Türkiye'de ne eski 6762 sayılı kanunda ne de yeni 6102 sayılı Türk Ticaret Kanunu'nda (TTK), 2006 İşK 994. maddesindeki haksız ayrımcılık davasıyla tamamen aynı olan bir hüküm bulunmamaktadır. Ancak, yargılama sonunda verilen tasfiye kararı, davacının paylarının satılarak bedelinin davacıya ödenmesi suretiyle pay sahibinin şirketten çıkarılması ve davanın başvuru koşulları gibi hususlar birlikte düşünüldüğünde, İngiliz İflas Yasası 1986'nın 122 (1) (g) maddesinde yer alan ve yukarıda analiz edilen tasfiye davası ve İŞK 994'te düzenlenen haksız ayrımcılık davasının birlikte TTK madde 531'de düzenlenen haklı sebeple fesih davasına karşılık geldiği söylenebilir.

Madde metni lafzen yorumlandığında ve Yargıtay'ın TTK 531.madde kapsamındaki kararları incelendiğinde, her ne kadar anılan maddenin yapımında teorik olarak İsviçre Borçlar Kanunu'nun ${ }^{246} 736$ (4). maddesinden esinlenilmiş olsa da, uygulamada İşK 994'de yer alan haksız ayrımcılık davasına benzediği görülecektir ${ }^{247}$.

TTK madde 531 uyarınca hâkim, fesih yerine, payların bedelinin davacı pay sahibine ödenerek davacı pay sahibinin şirketten çıkarılmalarına veya duruma uygun düşen ve kabul edilebilir başka bir çözüme karar verebilir. Burada hâkime tanınan seçim hakkı düşünüldüguünde alışlagelmiş İsviçre hukuk sisteminin aksine hâkime geniş bir takdir yetkisi verildiği görülecektir. Nitekim hâkim davacının fesih talebiyle bağlı değildir. Bu yönüyle TTK madde 531'in hâkime geniş bir takdir yetkisi tanıyan İngiliz hukukuna yakın olduğu söylenebilir ${ }^{248}$. Sadece takdir hakkı bakımından değil ayn zamanda TTK madde 531'de "Mahkeme, fesih yerine, davact pay sahiplerine, paylarının karar tarihine en yakın tarihteki gerçek değerlerinin ödenip davacı pay sahiplerinin şirketten çıkarılmalarına veya duruma uygun düşen ve kabul edilebilir diğer bir çözüme karar verebilir." ifadesi de İşK 994. maddesi ile benzerlik taşımaktadır. Nitekim İsviçre Borçlar Kanunu'nun ${ }^{249} 736$ (4). maddesinde yalnızca “diğer çözümlere" atıfta bulunulmaktadır. Ancak İşK madde 994'ün devamı olan 996. maddesinde de açıkça davacı pay sahibinin paylarının satılarak pay sahibinin şirketten çıkarılması düzenlenmektedir ${ }^{250}$.

\footnotetext{
246 İsviçre Borçlar Kanunu; madde 736/4.

247 Veziroğlu (n 9) 533.

248 ibid 534.

249 İsviçre Borçlar Kanunu; madde 736/4.

2502006 İngiliz Şirketler Kanunu <https:// https://www.legislation.gov.uk/ukpga/2006/46/section/996> Erişim Tarihi $06 / 12 / 2020$
} 
Yeni TTK'nın yürürlüğe girmesiyle birlikte 531. maddeye ilişkin olarak Yargıtay tarafından verilen karar örneklerine bakıldığında görülecektir ki, Yargıtay'ın şirketin feshine karar vermesi için şirketin mali durumunun gerçekten çok kötü olması ve artık toparlanamayacak durumda olmas1 gerekmektedir ${ }^{251}$. Mahkeme feshe karar verilebilmesi için yeterli haklı sebeplerin varlığında davacı pay sahibinin paylarının satılmasına karar verebilmektedir ${ }^{252}$. İngiliz hukukunda da İŞK 994. madde kapsamında mahkeme tarafından en çok tercih edilen çözüm paylarının satılarak davacı pay sahibinin şirket pay sahipliğinden çıkarılmasıdır ${ }^{253}$.

TTK madde 531 ile İŞK madde 994 arasında birtakım farklılıklar da bulunmaktadır. Bunlardan birincisi İngiliz hukukunda haksız ayrımcılık davası açabilmek için belli bir pay sahipliği oranı aranmamaktadır. Yukarıda da anlatıldığı üzere pay oranına bakılmaksızın şirketin her bir pay sahibi İşK 994. madde kapsamında mahkemeye başvurabiliir ${ }^{254}$. Buna karşılık Türk Ticaret Kanunu 531. maddesi uyarınca, anonim şirketin haklı sebeple feshi davasında, davacı sıfatına haiz olabilmek için pay sahiplerinin halka kapalı anonim şirketlerde sermayenin en az onda birini ve halka açık şirketlerde yirmide birini temsil eden paylara sahip olması gerekmektedir ${ }^{255}$. Bu düzenleme ile kanun koyucu davacı sıfatının kim yahut kimlere ait olduğunu açıkça belirtmiştir. Bu yönüyle kanun koyucu davayı açmak için haklı sebebin varlığını yeterli görmemiş ve davayı açmak için menfaati olan kişilerden sadece bazılarının TTK madde 531 kapsamında davacı olarak kabul edilebileceğini belirtmiştir ${ }^{256}$. Belirtilmelidir ki söz konusu dava maddede önerilen oranda paya sahip tek bir pay sahibi tarafından açılabileceğ $i^{257}$ gibi bu orana sahip birden fazla pay sahibi tarafından toplu olarak da açılabilir ${ }^{258}$.

Türk Ticaret Kanunu incelendiğinde, 531. maddede haklı sebeple fesih davas1 açabilmek için davacıda aranılan azami pay sahipliği oranının şirketteki pay sahiplerinden gelen şirketin feshine yönelik gereksiz talepleri önlemeye ve şirketin yönetiminde istikrarı korumaya yönelik olduğu söylenebilir. Nitekim gereksiz ve çok sayıda yapılan haklı sebeple fesih talepleri şirketin işleyişini etkileyecek ve aksamalara sebebiyet verebilecektir. Özellikle bu taleplerin sonunda mahkeme tarafından "şirketin feshi” kararının verilebilecek olması hususu bu davaya şirketler

\footnotetext{
251 Bknz Yargitay $11 \mathrm{HD}, 8840 / 17428,06.07 .2015$; Yargitay $11 \mathrm{HD}, 10302 / 6768,12.10 .2015$; Yargitay $11 \mathrm{HD}, 13242 / 6721$, 14.12.2015; Yargitay 11 HD, 5272/2552, 11.10.2017.

252 Yargitay 11 HD, 2015/8166, 11.07.2015; Yargitay 11 HD, 12331/17416, 19.11.2015.

253 French, Mayson ve Ryan (n 52) 695.

2541986 İngiliz İflas Yasası; madde 122.

2556102 sayılı Türk Ticaret Kanunu; madde 531.

256 Emel Hanağası, "Anonim Ortaklığın Haklı Sebeple Feshi Davasının Medeni Usul Hukuku Perspektifinden Değerlendirilmesi”, (2016) 32 BATIDER 1, 207.

${ }_{257}$ Bu husus Türk Ticaret Kanunu m.531'in gerekçesinde de belirtilmektedir. Bknz ‘6102 Sayılı Türk Ticaret Kanunu Gerekçesi madde 531' (Ticaretkanunu.net, 2018) <http://www.ticaretkanunu.net/wp-content/uploads/2010/04/Turk-Ticaret-KanunuMadde-Gerekceleri.pdf $>$ Erişim tarıhi 26 Aralık 2020.

258 Ayşe Şahin, Anonim Ortaklı̆̆ın Haklı Sebeple Feshi (1. Bası, Vedat 2013).
} 
hukukunda ayrı bir önem atfetmektedir. Nitekim şirketin feshine karar verilmesi halinde sonuçları şirketin pay sahiplerini, kendi tüzel kişiliğini ve hatta şirket alacaklılarını dahi etkileyecektir.

Pay oranının şirket ana sözleşmesi ile indirilip indirilemeyeceği hususu öğretide tartışmalıdır. Bu oranın arttırılamayacağ mevcuttur. TTK' da azınlık pay sahibi olabilmek için gerekli olan yasal pay sahipliği sınırı konusunda bir değişiklik yapılıp yapılamayacağı hususunda açık bir hüküm bulunmamaktadır. Ancak TTK madde 340 uyarınca esas sözleşme ile kanunda düzenlenen anonim şirketlere ilişkin hususlarda bir değişiklik yapılabilmesi için Kanunda buna açıkça izin verilmiş olması gerekmektedir ${ }^{259}$. Ve yine TTK madde 411 uyarınca esas sözleşmeyle genel kurulu toplantıya çağırma hakkı daha az sayıda paya sahip pay sahiplerine tanınabilir. Burada kanun koyucu normalde sadece şirket sermayesinin en az onda birini, halka açı şirketlerde yirmide birini oluşturan pay sahiplerine tanınan bu genel kurulu toplantıya çağırma hakkını esas sözleşmede kararlaştırılması kaydıyla daha az oranda paya sahip pay sahiplerine de tanımıştır ${ }^{260}$. İşte bu TTK'nın bu iki maddesi, 340 ve 411, birlikte düşüldüğünde, öğretide bazı yazarlar pay oranının esas sözleşme ile düşürülerek madde 531 kapsamında haklı sebeple fesih davası açılabilmesi için de aynı m.411'de olduğu gibi açık bir hüküm bulunması gerektiğini savunmaktadir ${ }^{261}$. Buna karşılık, Helvac ${ }^{262}$ ve Bahtiyar $^{263}$ gibi, madde 531'de aranılan söz konusu pay oranının esas sözleşme ile değiştirilebileceğini dolayısıyla bu oranın arttırılması söz konusu olmasa da daha düşük bir oranın pay sahipleri arasında kararlaştırılabileceğini savunan görüşler de mevcuttur. ${ }^{264}$ Erdem de 411. Maddenin azınlık hakları konusunda genel bir düzenleme getirdiğini ve dolayısıyla diğer azınlık hakları bakımından da esas sözleşme pay oranının indirilmesinin m.340 anlamında izin verilen bir durum olduğunu savunmaktadır. Kanaatimizce, TTK madde 531'e başvurmak için aranılan pay sahipliği oranının esas sözleşme ile arttırılamaması ancak indirilebilmesi azınlık pay sahiplerinin haklarının korunmasını genişletecektir ve faydalı olacaktır. Ancak her ne kadar TTK madde 531 'in gerekçesinde de bu duruma cevaz verilmiş olsa bile TTK madde 340'ta bu hususta emredici hüküm bulunduğunun ve dolayısıyla bu oranın esas sözleşme ile

\footnotetext{
259 Rauf Karasu, 'Emredici Hükümler İlkesinin Kapalı Tip Anonim Şirketler ve Limited Şirketler Açısından Doğurduğu Sorunlar ve Çözüm Önerileri’ (2015) Ticaret ve Fikri Mülkiyet Hukuku Dergisi 1, 116.

260 Seda Güngör, ‘6102 Sayılı Türk Ticaret Kanunu Hükümleri Kapsamında Anonim Şirketlerde Azınlığa Tanınmış Olan Haklar' (2015) Tekirdă SMMM Odası Sosyal Bilimler Dergisi, 4, 4.

${ }_{261}$ Fatih Bilgili ve Ertan Demirkap1, Şirketler Hukuku Dersleri (6. Bası, Dora 2018) 302; Füsun Nomer Ertan, 'Anonim Ortaklığın Haklı Sebeple Feshi Davası- TTK m. 531 Üzerine Düşünceler' (2015) 23 İstanbul Hukuk Mecmuası 421, 424 Nomer Ertan also argues that it is not possible to reduce the legal shareholding threshold with the articles of association in the remedy of dissolution of the company for just causes under Article 531 of TCC.

262 Mehmet Helvacı, Anonim Ortaklıkta Ticaret Kanunundan Kaynaklanan Azınlık Haklarının Hukuki Niteliği ve Tanımı, Prof. Dr. Oğuz İmregün'e Armağan (Beta, 1998) 297.

263 Mehmet Bahtiyar, Ortaklıklar Hukuku (10. Bası Beta 2014) 286.

264 Helvacı, Anonim Ortaklıkta Ticaret Kanunundan Kaynaklanan Azınlık Haklarının Hukuki Niteliği ve Tanımı (n 263) 297; Bahtiyar (n 264) 286; Güngör (n 261) 4; Hasan Pulaşl1, 'Şirketler Hukuku Şerhi' (3. Baskı, Adalet 2018), 2005.
} 
indirilmesinin ancak TTK' da açıkça öngörülmesi durumunda ${ }^{265}$ mümkün olduğunun kabulü gerekmektedir.

Haklı sebeple fesih davasına başvurmak için aranılan pay sahipliği oranına ilişkin değinilmesi gereken bir diğer husus da davayı açabilmek için pay sahibinin sahip olması gereken pay oranının davanın açıldığı tarihte var olmas1 $1^{266}$ ve dava boyunca korunmasının gerekliliğidir ${ }^{267}$. Dolayısıyla, anonim ortaklığın haklı sebeple feshine ilişkin mahkemeye talepte bulunulmasından mahkemenin kararı kesinleşinceye kadar davacı, kapalı anonim ortaklıklarda yüzde 10'luk(halka açık şirketlerde ise yüzde $5^{\prime}$ lik) gerekli pay oranına sahip olunmalı ve bu oranı korumalıdır ${ }^{268}$. Ayrıca, temyize gidilmesi halinde davacı temyiz kararı mahkeme tarafından verilene kadar hisselerini en az yüzde 10 oranında tutmalıdır ${ }^{269}$. Buna göre kanunda belirlenen orandaki pay sahipliği sıfatı, hem haklı sebeplerin ortaya çıktığı anda hem de dava esnasında mevcut olmalıdır. Davanın başında mevcut olan oranın çeşitli sebeplerle düşmesi yahut kaybedilmesi halinde, Pulaşlı'ya göre, davacının haklı sebeple fesih davası açmakta menfaati kalmayacağından ve bu dava hakkı şahsa bağlı yenilik doğuran bir dava hakkı olduğundan ve bu nedenle payları devralana geçmediğinden dava düşer ${ }^{270}$. Yine Hanağası, payların oranının dava sırasında düşmesi halinde davanın dava şartı yokluğundan reddedilmesi gerektiğini savunmaktadır ${ }^{271}$. Bu gibi hallerde bazı yazarlar tarafindan davayı reddetmeden önce en azından gerekli miktarda pay oranına ulaşmak için davacıya bir süre verilmesi önerilmektedir ${ }^{272}$. Ancak, bu öneri mahkeme tarafindan uygulansa bile, söz konusu pay oranı hissedarların bu başvuruya başvurmaları için bir engel olmaya devam etmektedir.

Bu durumun bir diğer sonucu olarak, eğer ki azınlık pay sahipleri TTK 531'inci maddeye dayanarak mahkemeden bir talepte bulunmuş ise dava boyunca, hatta hüküm kesinleşinceye kadar şirketteki payları için iyi bir teklife sahip uygun bir alıcı bulsa bile paylarının tamamını yahut herhangi bir kısmını satamaz. Dahası, paylarının belli bir kısmını satmış olması neticesinde pay oranının yüzde 10'un altında kalmış olması halinde haklı sebeplerin varlığı ve dava açmaktaki menfaati şirkette sahip

\footnotetext{
265 Aynı görüş için bknz Nomer Ertan (n 262) 424.

266 Şahin (n 259) 346.

267 Pulaşlı (n 265) 2423; Şahin (n 259) 346; Abuzer Kendigelen, ‘İptal Davası Açma Hakkı ve Pay Sahipliği Sıfatının Cüz’i Halefiyet (Payların Devri) Sonucu Değişmesi' (2001) 1 Prof. Dr. Hayri Domaniç'e 80. Yaş Günü Armağanı, 307-331, 319; Nuri Erdem, Anonim Ortaklı̆̆ın Haklı Sebeple Feshi (2. bası, Vedat 2019) 180; Murat Oruç, '6102 sayılı Yeni Türk Ticaret Kanunu'na Göre Anonim Ortaklıktan Haklı Sebeple Fesih İstemine Bağlı Çıkarılma’ (2011) 27 Banka Huk. Dergisi, 209.

268 Öğretideki bir görüşe göre TTK m.531'de yer alan "en az" ifadesinden dolayı esas sözleşme ile daha düşük bir oran öngörülebilir. Bknz madde Gerekçesi; ayrıca Mehmet Emin Bilge, 'Anonim Şirketin Sona Ermesi ve Tasfiyesi' (2012) 16 Erzincan Üniversitesi Hukuk Fakültesi Dergisi 3, 261, 272; Pulaşlı (n 265) 576; Ayşe Sümer, 'Anonim Ortaklıkların Haklı Nedenle Feshi' (2012) 18 Marmara Üniversitesi Hukuk Fakültesi Hukuk Araşttrmaları Dergisi 2, 839-850; Bu orana karar verilirken esas alınması gereken değer "payların itibari değerinin esas sermaye oranı" olmalı ve sermaye bakımından da başlangıç sermayesi veya arttırılmış sermaye dikkate alınmalıdır; Hanağası (n 257) 207.

269 Şahin (n 259) 297.

270 Pulaşlı (n 265) 2423.

271 Hanağası (n 257) 216.

272 Pekcanıtez, Atalay ve Özekes (n 148) 429.
} 
olduğu mevcut paylar için devem ediyor olsa dahi 531. madde kapsamında fesih talebine devam edemez ${ }^{273}$.

İfade etmek gerekir ki haklı sebeple fesih hakkı 6102 sayılı Türk Ticaret Kanunu ile pay sahiplerine verilen en önemli haklardan biridir. Kapsam olarak da pay sahipleri için oldukça önemli bir oranda koruyuculuk içermektedir. Ancak bu hakka başvurulabilmek için pay sahiplerinde aranılan pay sahipliği oranıyla ilgili olarak ortaya çıkan sorunlar hakkın kullanım alanını daraltmakta ve dolaysıyla azınlık pay sahipleri için sağlanan yasal korunmayı sınırlamaktadır. İngiliz Şirketler Kanunu 994. maddesinde olduğu gibi herhangi bir pay sınırı aranmaksızın bu hakka bütün pay sahiplerince başvurulabilmesi ihtimali düşünülebilir. Nitekim bu hakkın pay oranına bakılmaksızın pay sahiplerinin hepsine tanınması durumunda davanın amaçlarından biri olan azınlık pay sahiplerinin korunması daha geniş sağlanacaktır. Nitekim her ne kadar haklı sebeple fesih anonim ortaklığın sona erme sebeplerinden biri olarak görülse de esasen davanın amacı çoğunluk pay sahiplerinin şirket içinde kötüye kullanım teşkil eden davranışlarına karşı azınlığa etkin bir şekilde korunmanın sağlanmasıdır ${ }^{274}$. Ancak her hâlükârda dikkat etmek gerekir ki bu dava İŞK 994'te düzenlenen haksız ayrımcılık davasından farklı olarak şirketin feshi ile sonuçlanabilecek bir davadır. İşte dava sonucunda mahkeme tarafından verilebilecek ve şirketin feshine dahi varabilecek olan kararların ağırlığı düşünüldüğünde dava şartı olarak belli bir paya sahip olunma şartının aranılıyor olması kabul edilebilir bir durumdur. Nitekim her ne kadar fesih kararı "ultima ratio" yani son çare olarak görülse de mahkemenin yargılama sonucu vereceği fesih kararı sadece davacıyı değil şirketi, şirket pay sahiplerini, şirketin alacaklılarını ve şirket çalışanlarını topluca ilgilendirmekte ve etkilemektedir ${ }^{275}$. Şirketler hukukunda azınlık pay sahiplerinin korunması önem arz etse de şirketin varlığının devam ettirilebilmesi daha önceliklidir. Pay oranına bakılmaksızın haklı sebeple fesih davası açma hakkının bütün pay sahiplerine tanınması şirketin feshi ile sonuçlanması bile şirkete karşı açılan fesih davalarının sayısını ve dolayısıyla şirketler hukukunda mahkemenin şirketin iç ilişkilerine müdahalesini arttıracaktır. Kanun koyucu madde 531 ile mahkemeye ve azınlık pay sahibine oldukça geniş yetkiler vermiştir. İşte aranılan bu pay oranı bir anlamda bu geniş yetkilerin pervasızca ve kötü niyetle kullanılmasının önüne geçebilmek için getirilmiş bir koşuldur ${ }^{276}$. Şu durumda şirkette ancak belirli bir sermayeye sahip olan pay sahipleri menfaatlerinin ihlal edildiğini düşündükleri hallerde mahkemeye başvurabilirler ve ancak bu halde mahkemenin şirkette gerçekleşen bir haklı sebep dolayısıyla şirkete bu dava aracılığıyla müdahalesi söz konusu olur.

\footnotetext{
273 Hanağası (n 257) 216.

274 Şahin (n 259) 47.

275 Hamdi Yasaman, ‘Türk Ticaret Kanunu Tasarısı'nda Hâkimin Genişleyen Rolü’ (2009) 25 BATIDER 4, 92; Ersin Çamoğlu, 'Anonim Ortaklığın Haklı Sebeple Feshinde Hakimin Takdir Yetkisi' (2015) 31 BATIDER 1, 9; Bilge (n 269) 273-274; Sümer (n 269) 839-850; Pulaşl1 (n 265) 1789; Şahin (n 259) 326-335; Erdem (n 268) 201.

276 Şahin (n 259) 47.
} 
6102 sayılı TTK madde 531 ile ilgili olarak değerlendirilmesi gereken bir diğer husus da maddede anılan ve dava açma şartı olarak aranılan "haklı sebeplerin varlığı" ifadesinden ne anlaşılması gerektiğidir. Kanun koyucu 531. maddede hâkime geniş bir takdir yetkisi vermektedir ${ }^{277}$. Bu durum pay sahipleri ve şirket bakımından bir belirsizliğe yol açabilir. Nitekim 531. maddede yer alan "haklı sebepler" kavramına ilişkin ortak bir anlayış yoktur. Ayrıca, anılan madde kapsamında mahkeme fesih yerine, davacı pay sahiplerine, paylarının karar tarihine en yakın tarihteki gerçek değerlerinin ödenip davacı pay sahiplerinin şirketten çıkarılmalarına veya duruma uygun düşen ve kabul edilebilir diğer bir çözüme karar verebilir ${ }^{278}$. Bu durum benzer "haklı sebeplerin" değerlendirilmesinin aynı kriterlerle yapılmasına rağmen bu sebeplerin varlığında farklı sonuçların ortaya çıkmasına neden olabilmektedir. TTK 531. madde kapsamında yapılan başvuruda, hâkim haklı sebeplerin varlığını değerlendirecek ve var olduğu kanısına vardığında şirketin feshine yahut diğer uygun çözüm yollarından birine karar verecektir. Mahkeme öne sürülen haklı sebeplere ilişkin değerlendirme yaparken bu sebeplerin feshe gerekçe olup olmayacağını değerlendirmektedir. Eğer davacı tarafindan iddia edilen haklı sebepler 531. madde kapsamında şirketin feshine sebep olabilecek gerekçeler içermiyorsa mahkeme davayı reddedecektir. Mahkeme ancak şirketin feshini haklı kılan olayların varlığında bu sorunları düzeltmek için karar verilebilecektir. Sonuç olarak haklı sebebin tespitinde, yargılama sonucu verilecek kararların ağırlığına göre yapılan bir değerlendirmeye yer verilmemektedir ${ }^{279}$. Esasen mahkemenin verebileceği farklı kararların şirketi ve pay sahiplerini etkileme oranına göre haklı sebeplerin varlığının değerlendirilmesi farklılık içermelidir. Şirketin feshine gerekçe olabilecek haklı sebepler ile fesih yerine pay sahibine paylarının karar tarihine en yakın tarihteki gerçek değerlerinin ödenerek davacı pay sahibinin şirketten çıkarılmasına karar verilmesine gerekçe olabilecek haklı sebepler farklı kriterle tespit edilmelidir. Bu durumda, mahkeme haklı sebebin var olmadığı ve dolayısıyla şirketin dağılmasına gerek olmadığı gerekçesiyle başvuranın talebini baştan reddedemez.

Türk hukukunda, İsviçre ve İngiliz hukuklarında olduğu gibi, ${ }^{280}$ dava açılırken davacı pay sahibi tarafindan fesih yerine belli bir çözümü istiyorsa bunu açıcça dava dilekçesine yazması zorunluluğu yoktur. Davacı tarafından özellikle bir çözüm yolunun talep edilmesi halinde de sorun yoktur. Mahkemenin takdir yetkisi oldukça geniştir ve talep edilen çözüm yolundan başka bir çözüme karar verebilir. Yani hâkim taleple bağlı

280 İngiliz Hukukunda İŞK 994. madde kapsamında mahkemeye başvuran davacı dava dilekçesinde dava sonucu hangi çözümü istediğini belirtmelidir. Mahkemeler de davacının talep ettiği çözümün şikâyet ettiği davranışa uygun olması şartıyla davacının bu isteğiyle bağlıdır. Karar verirken davacının talebini dikkate alarak karar verir. Bknz Re J E Cade and Son Ltd [1992] BCLC 213, p 223; Sarah Worthington, Sealy and Worthington's Text, Cases and Materials in Company Law (11. Bası, Oxford University Press 2016) 726.
} 
değildir ${ }^{281}$. Burada kanun koyucunun amacı hâkimin sadece feshe karar vermesi yahut davayı reddetmesini önlemek ve onu bu ikilemden kurtararak somut olayın şartlarına uygun düşen, kabul edilebilir ve ölçülü bir karar vermesini sağlamaktır ${ }^{282}$.

TTK madde 531 kapsamında tartışma konusu olan hususlardan biri de mahkemenin fesih dışında bir karara hükmedebilmesi için davacı azınlık tarafından ileri sürülen sebeplerin şirketin feshini gerektirir nitelikte olmasının gerekip gerekmediğidir. Bazı yazarlar, davacı tarafından ileri sürülen sebebin haklı olmasının yetmeyeceğini aynı zamanda bu sebebin şirketin feshini gerektirecek kadar ağır nitelikte bir sebep olmas1 gerektiğini savunmaktadır ${ }^{283}$. Buradan varılan sonuca göre TTK madde 531 kapsamında açılan bir davada, mahkeme, haklı sebebin şirketin feshini gerektirecek nitelikte olmadığına karar verirse duruma uygun düşecek diğer çözüm yollarını değerlendirmeksizin davayı reddedecektir. Kanaatimizce, şirketin haklı sebeple fesih davasıyla sadece kötü yönetimden dolayı işlemez hale gelen ve amacını gerçekleştirmekte zorlanan şirketin fesih yoluyla sona ermesi değil, aynı zamanda azınlığın çoğunluk karşısında hak ihlâllerine karşı korunmasının amaçlandığ 1 düşünüldüğünde; haklı sebep feshe gerekçe olabilecek nitelikte olmasa bile dava doğrudan reddedilememelidir. Mahkeme, alternatif çözüm yollarının davacının sorununu çözüp çözemeyeceğini değerlendirmeli ve eğer uygunsa fesih yerine bu çözüm yollarından birine karar vermelidir. Tekinalp de mahkemenin alternatif çözümü uygun görmesi halinde haklı sebebin feshi gerektirecek kadar ağır olmasına gerek olmadığını belirtmiştir ${ }^{284}$. Nitekim, feshe gerekçe olabilecek bir sebeple, örneğin, payların satılmasını gerekçe olabilecek bir sebebin aynı ağırlıkta olmayacağ 1 ortadadır. Her iki çözüm yolu için de aynı standartlar ölçüsünde değerlendirme yapılırsa çoğunluğun şirket içinde azınlığa karşı sergilemiş olduğu baskıcı tutum ortadan kaldırılamayacak ve davanın amaçlarından birine ulaşılamamış olacaktır ${ }^{285}$.

\subsection{Türk Ticaret Kanunu madde 531'e Yönelik Öneriler}

Anonim şirketlerde kar elde etmek amacıyla bir araya gelmiş çok sayıda pay sahibi bulunur. İşte bu şirketlerde geçerli olan çoğunluk ilkesi, bazen azınlık pay sahiplerinin

\footnotetext{
281 Ünal Tekinalp, 'Anonim Ortaklı̆̆ı Haklı Sebeplerle Feshi Davasının Bazı Usulî Sorunları', Ersin Çamoglu'na Armağan (1. Bası, Vedat 2013), 214.

${ }^{282}$ Cengiz Erten, 'Anonim Şirketlerde Haklı Sebeplerle Fesih Hakkının Yargıtay İçtihatları Çerçevesinde Değerlendirilmesi' (2019) 13 Uyuşmazlık Mahkemesi Dergisi, 187-211, 199; Tekinalp, Anonim Ortaklı̆̆ın Haklı Sebeplerle Feshi Davasının Bazı Usulî Sorunları (n 282) 213.

283 Aytekin Çelik, Anonim Şirketlerde Ortaklıktan Çıkarılma, (3. Bası, Seçkin 2016); Erten (n 283) 187-211, 199; Oruç (n 268) 227; Çamoğlu (n 276) ; Şahin (n 259) 125.

284 Ünal Tekinalp, 'Türk Ticaret Kanunundaki Boşluk: Anonim Ortaklığın Feshi, Çoğunluk Gücünün Kötüye Kullanılmasına Karşı Etkili Bir Araç' (1974) 21 İktisat ve Maliye Dergisi 8, 321-326.

285 Bazı yazarlarca feshe karar verilmesini gerektirmeyen bir ağırlığa ulaşmayan haklı sebeplerin varlığında davacının şirketten çıkmasına karar verilmesinin TTK m. 531'de düzenlenen bu dava hakkının azınlık tarafından ortaklıktan çıkma aracı olarak kullanılması sonucunu doğuracağı savunulmaktadır. Ancak eğer fesih ve alternatif çözüm yolları için haklı sebebin varlı̆̆ının tespitinde aynı standartlar uygulanırsa, şu haliyle m.531'in azınlık pay sahiplerinin şirketteki haklarının korunması adına pek başvurulan bir yol olmayacağı ortadadır. Karşııt görüş için bknz Çelik (n 284) 14.
} 
haklarının çoğunluğun aldığı kararlar nedeniyle ihlal edilmesine yol açabilir. İşte bu gibi hallerde başvurulabilmesi için kanun koyucu azınlığa haklı sebeple fesih davası açma hakkı tanımıştır. 6102 sayılı TTK madde 531 ile azınlık pay sahiplerine tanınan haklı sebeplerin varlığında fesih davası açma hakkı, TTK'da yer alan azınlık pay sahiplerinin sahip olduğu en koruyucu ve en önemli haklardan biridir. Bizim hukukumuzda anonim şirketlerde çıkma veya çıkarılma hakkının bulunmadığı göz önünde bulundurulduğunda bu hakkın önemi daha da artmaktadır ${ }^{286}$.

Ancak belirtmek gerekir ki, yukarıda anılan davaya ilişkin sorunlar nedeniyle hakk1 sebeple fesih davası açma hakk1 uygulamada azınlığa henüz beklenilen korumayı sağlayamamaktadır. Kanaatimizce, özü gereği fesih sonucuna bağlanmış olması bu dava hakkının uygulanabilirliğini zorlaştırmaktadır. Öncelikle dava açmak için gerekli olan pay sahipliği oranı ve bu oranın dava boyunca korunmasının gerekliliği yasal oranı karışlayamayan pay sahiplerinin şirket içinde sorun yaşasalar dahi bu hakka başvurmalarına engel olmaktadır. Yukarıda da açıklandığı gibi sonucu sadece davacıyı ya da şirketi değil aynı zamanda şirketin yöneticilerini, diğer pay sahiplerini ve hatta alacaklılarını dahi etkileyebilecek olan böyle bir davada, davacıda başvuru şartı olarak belli bir pay oranın varlı̆̆ının aranması kabul edilebilir bir durumdur. Yargilama sonunda mahkeme tarafindan verilecek anonim ortaklığın feshi kararı doğurduğu ekonomik ve sosyal sonuçlar dolayısıyla 3. kişilerin menfaatlerine dahi etki eden hukuki sonuçlar doğurabilmektedii ${ }^{287}$. Bunun yanında, haklı sebeplerin neler olacağ 1 konusunda TTK madde 531'de açıkça tanım yahut herhangi bir örnek bulunmaması nedeniyle uygulamada sorunlar çıkabilmektedir. Her ne kadar öğretide ${ }^{288}$ ve Yargıtay ${ }^{289}$ kararlarında alternatif çözüm yolları tartışılmaksızın feshe karar verilmesinin bozma sebebi olduğu kabul edilse de haklı sebebin feshi gerektirecek kadar ağır nitelikte olmadığı durumlarda diğer çözüm yolları düşünülmeksizin davanın reddedilecek olması bir sorun teşkil etmektedir.

TTK madde 531 kapsamında haklı sebebin içeriğinin nasıl belirleneceği, hangi hallerin haklı sebep teşkil edip hangilerinin etmeyeceği de yine incelenmesi gereken bir husustur. Davacı tarafindan sunulan sebeplerin TTK madde 531 kapsamında haklı sebep olarak değerlendirilebilmesi için anonim ortaklığın devamının tehlikede olmas1 ${ }^{290}$ ve neticede davacı pay sahipleri dışında kalan diğer menfaat sahiplerinin menfaatlerinin (örneğin; diğer pay sahiplerinin, çalışanların, 3. kişilerin menfaatlerinin) şirket ayakta kalırsa daha fazla etkilenecek olması

\footnotetext{
286 Erten (n 283)188.

287 Şahin (n 259) 117.

288 Aytrkin ÇELIK, 'Türk Ticaret Kanunu Tasarısı'na göre Anonim Şirketlerin Haklı Sebeple Feshi' (2009) 25 BATIDER 4, 578; Erdem (n 268) 252.

289 Yargitay 11 HD, 9088/2352, 03.03.2016.

290 Tekinalp, Anonim Ortaklı̆̆ın Haklı Sebeplerle Feshi Davasının Bazı Usulî Sorunlarl (n 282) 218.
} 
gerekmektedir ${ }^{291}$. Öğretide kabul edilen genel görüşe göre pay sahipleri arasındaki çekişmeler istisnai olarak haklı sebep kabul edilebilecektir ${ }^{292}$. Pay sahipleri arasındaki ilişkilerin haklı sebep kabul edilebilmesi için ortaklar arasındaki güven ilişkisinin tamamen sarsılmış olması yahut ortaklar arasında çok ciddi ve yargıya intikal etmiş geri dönülemeyecek şekilde anlaşmazlıkların ortaya çıkmış olmas1 gerekmektedir ${ }^{293}$. Yargıtay da olayda haklı sebebin var olup olmadığını değerlendirirken şirketin pay sahiplerinin arasındaki kişisel ihtilafları ve söz konusu şirketin aile şirketi olup olmadığını araştırmaktadır ${ }^{294}$. Esasen, pay sahipleri arasındaki kişisel ilişkilerin, anonim ortaklıklar gibi sermayenin bir araya gelmesiyle kurulmuş olan ve pay sahiplerinin kişiliğinden bağımsız olan ortaklıklarda fesih sonucuna sebebiyet verebilmesi nedeniyle şirketler hukuku açısından bakıldığında mümkün olmamalıdır ${ }^{295}$. Ancak, yukarıda da anıldığ 1 gibi haklı sebeple fesih davasının azınlık pay sahiplerini çoğunluğa karşı koruma fonksiyonu göz önünde bulundurulduğunda bu ilişkilerin haklı sebep olarak değerlendirilmesi istisnai olarak düşünülebilir. Nitekim haklı sebeple fesih davası sadece fesihle sonuçlanan bir dava değildir. Kişisel ilişkilerinden dolayı bu davayı açan ortağın paylarının satın alınarak şirketten çıkarılması düşünülebilir.

Yine, haklı sebeple fesih davasında çoğunluk pay sahiplerine karşı da husumet yöneltilmesi ve bunun neticesinde mahkeme tarafindan davacinın paylarının çoğunluk pay sahiplerince satın alınmasına karar verilemeyeceği kabul edilmektedir. Acaba özellikle kişisel ilişkilerde bozulmaların görüldüğü, azınlığın yönetimden dışlandığını düşündüğü için dava açtığı durumlarda, davalı olarak çoğunluk pay sahipleri de kabul edilse ve davacının paylarının İ̧̧K 996. maddesinde ${ }^{296}$ düzenlendiği gibi çoğunluk tarafından satın alınmasına karar verilse nasıl olur? Burada, söz konusu olan çoğunluk pay sahiplerinin davalı olarak kabul edilmesi olduğundan kanaatimizce davaya taraf olmayan bir pay sahibinin pay almaya zorlanmas1 gibi bir durum söz konusu olmayacaktır ${ }^{297}$. Ancak yine madde 531'in isminde dahi yer aldığı şekilde şirketin feshiyle sonuçlanabilecek bir dava olduğu düşünüldüğünde çoğunluğa yöneltilmiş olan husumetin bir anlamı olmayacaktır. Eğer davanın içeriğinde fesih hakkı olmasayd1, kanun koyucu sadece

\footnotetext{
291 Nomer Ertan (n 262) 426; Erdem (n 268) 102.

292 Nomer Ertan (n 262) 426; Şahin (n 259) 114; Özge Ayan, 'Yeni Türk Ticaret Kanununda Anonim Şirketin Haklı Sebeplerle Feshi Davas1 (531. Madde)' (2011) 9 Legal Hukuk Dergisi 102, 2244.

293 Erten (n 283) 196.

294 Yargitay 11 HD, 18024/12808, 01.12.2015; Yargitay 11 HD, 4504/12980, 23.12.2015; Yargitay 11 HD, 5994/13820, 11.10.2017; Yargitay 11 HD, 2552/5272, 16.11.2018.

295 Tekinalp, Anonim Ortaklı̆̆ın Haklı Sebeplerle Feshi Davasının Bazı Usulî Sorunları (n 282) 426.

2962006 İngiliz Şirketler Kanunu; madde 996.

297 Ertan, çoğunluk pay sahibine ilgili azınlık payları satın alması konusunda bir teklif götürülebileceğini ancak davada taraf olmayan bir pay sahibinin mahkeme kararı ile dahi "pay" satın almaya zorlanmasının mümkün olmayacağını savunmaktadır. Bknz Nomer Ertan (n 262) 426. Aynı görüş için bknz Tekinalp, Anonim Ortaklığın Haklı Sebeplerle Feshi Davasının Bazı Usulî Sorunlart (n 282) 215; Bilge (n 269) 277; Şahin (n 259) 352; Hanağası (n 257) 223.

Bizim önerimize göre çoğunluk pay sahipleri zaten şahsen ya da şirketle birlikte davalı olacağı için mahkeme davayı bu şekilde değerlendirecek ve dolayısıyla pay almaya zorlanmaları gibi bir durum olmayacaktır.
} 
payların satılmasından ve diğer alternatif çözümlerden bahsetseydi bu öneri kabul görebilirdi ${ }^{298}$.

Haklı sebeple fesih davasına ilişkin yukarıda anılanlar ve bunlara benzer sorunlar, tartışmalar yıllardan beri mevcuttur. Kanaatimizce TTK madde 531 kapsamında ortaya çıkan sorunların çözümünü uygulamaya bırakmak yerine bazı köklü değişiklikler yapılabilir. İngiliz hukukunda olduğu gibi 531. maddenin iki farklı kanun yolu şeklinde düzenlenmesi düşünülebilir. Yukarıda da andığımız gibi yargılama sonunda verilen tasfiye kararı, davacının paylarının satılarak bedelinin davacıya ödenmesi suretiyle pay sahibinin şirketten çıkarılması ve davanın başvuru koşulları gibi hususlar birlikte düşünüldüğünde, İngiliz İflas Yasası 1986'nın 122 (1) $(\mathrm{g})^{299}$ maddesinde yer alan ve yukarıda analiz edilen tasfiye davası ve İŞK 994'te düzenlenen haksız ayrımcılık davasının birlikte TTK madde 531'de düzenlenen haklı sebeple fesih davasına karşılık gelmektedir. Türk hukukunda da bir şirketin işini yapma veya karar verme şeklinden rahatsız olan yahut kişisel ilişkilerden kaynaklı bir haklı sebebi bulunan pay sahiplerine şirketin feshine dayanmayan daha esnek ve daha koruyucu bir hak tanınabilir. Yine haklı sebeplerin varlığında şirketin feshi hakkı da ayrı bir madde ile TTK ‘da veya İngiltere'de olduğu gibi İcra ve İflas Kanunda düzenlenebilir. Mevcut sistemde kural olarak, haklı sebeple fesih davasından önce yönetim kurulu sorumluluk davası veya iptal davası gibi başka davalarla çözüm yolu aranması veya diğer azınlık haklarına başvurulmuş olması zorunluluğu yoktur ${ }^{300}$. İngiliz İflas Kanununun 125 (2) maddesine ${ }^{301}$ göre ise eğer davacının şirketteki pozisyonunu düzeltmek için yahut şikâyetlerini giderebilmek için başvurabileceği başka bir yol varsa mahkeme tasfiyeden önce o çözüm yoluna gitmelidir. Yani şirketin tasfiyesi son çaredir ${ }^{302}$. Bizim önerdiğimiz sistemde getirilecek olan iki farklı dava için de aynı şart aranabilir. Yani haklı sebeplerle fesih davası açabilmek için fesih yerine payların satılarak bedelinin davacıya ödenmesi ya da diğer bir uygun çözüm içeren dava hakkının kullanılması şartı aranabilir.

Şu hâlde davacı fesih talebiyle dava açtığında fesih kararına hükmedilebilmesi için şirketin tasfiyesine dayanak teşkil edebilecek nitelikte haklı sebepleri bulunduğunu ispat etmek zorundayken; fesih içermeyen diğer dava hakkı için şirkette pay sahipliğinin devamının zor olduğunu, kâr payını uzun süredir alamadığını ya da mesela çoğunluk tarafından şirketin yönetiminden dışlandığını ispat etmesi yeterli olacaktır. Her ne kadar iki dava birbirine benzer görünse ve gerekçeleri benzer olsa da fesih içermeyen kanun yolunun hem azınlık pay sahiplerinin korunması için daha kapsamlı

\footnotetext{
298 İngiliz hukukunda 994. madde ve devamında düzenlenen haksız ayrımcılık davası sonunda fesih kararı verilebilecek bir dava değildir. O nedenle husumetin çoğunluğa karşı da yönetilmesi sorun teşkil etmemektedir.

2991986 İngiliz İflas Yasas1; madde 122.

300 Sümer (n 269) 839-850; Pulaşlı (n 265) 127; Oruç (n 268) 215; Nomer Ertan (n 262) 428.

3011986 İngiliz İflas Yasası; madde 125.

302 Boyle ve Birds ve diğerleri (n 36) 675.
} 
olduğu hem de şirketin devamlılığı ve yatırımcılara güven verilebilmesi için daha güvenilir olduğu ortadadır. Nitekim fesih içermeyen bu dava hakkı daha kapsamlı ve koruyucudur azınlık için çünkü ispat yükü hafiflemiştir. Yukarıda anılan TTK madde 531'e yönelik ortaya çıkan sorunlardan biri olan paylarının karar tarihine en yakın tarihteki gerçek değerlerinin ödenip davacı pay sahiplerinin şirketten çıkarılmalarına veya duruma uygun düşen ve kabul edilebilir diğer bir çözüme karar verebilmesi için bile haklı sebebin feshi gerektirecek ağırlıkta olması ve bunun davacı tarafindan ispat edilmesi zorunluluğu ortadan kalkacaktır. Şirkette pay sahipliğinin devamının zor olduğunu, çoğunluk tarafindan şirketin yönetiminden dışlandığını ya da örneğin şirket yönetiminin sorunlu olduğunu ispat etmesi ve bu nedenle pay sahipliğinden ayrılmak istediğini ya da sorunun mahkeme tarafindan ortadan kaldırılmasını talep etmesi yeterli olacaktır. Nitekim artık haklı sebeple fesih davasında mevcut olan fesih tehlikesi bu yeni davada mevcut değildir dolayısıyla dava sonucu hem şirket için hem de şirketle alakalı diğer kişiler yani pay sahipleri, alacaklılar, kredi verenler için daha ağır sonuçlara yol açmayacaktır. Zaten çoğu zaman davacının sorunlarının çözümü için çoğu zaman paylarının devralınarak şirketten ayrılması yeterli olacaktır.

Önerildiği şekilde düzenlenen fesih içermeyen dava hakkına başvurabilmesi için İngiliz hukukunda olduğu gibi dava şartı olarak belli bir pay oranının aranılmaması düşünülebilir. Bu durumda şirket için fesih gibi ağır bir netice ile karşılaşılması sorunu olmayacaktır. Bu durum payları için iyi bir bedel bulamayan pay sahiplerinin dava açarak paylarını sattırma yoluna gitmelerine ve dolayısıyla dava sayısının artmasına ve mahkemenin şirketin işleyişine müdahale etmesine yol açabilir. Ancak mevcut hukuk sistemimizde TTK madde 553-555'te düzenlenen yönetim kurulu sorumluluk davası ya da TTK madde 445 'te düzenlenen genel kurul kararlarının iptali davası da aynı şekilde riskler içermelerine rağmen davacıda başvuru şartı olarak belli bir pay oranının varlığının aranmadığı davalardır. Söz konusu hakkın pay oranı aranmaksızın tüm pay sahiplerine verilmesi halinde bu hak ile Türk hukukunda azınlık pay sahiplerine tanınan korumanın kapsamı oldukça genişleyecektir.

Mevcut düzenlemede madde 531 kapsamında pay sahipleri şirketi feshe götürebilecek kadar önemli bir hakka sahip olduğu için bu hak teoride azınlık hissedarlarının korunması için ideal görünse de pratikte öyle değildir. Şirketin feshi hukuki olarak şirketin artık mal varlı̆̆ına hak ve yükümlülüklere sahip olamaması ve hatta şirketin sözleşmelerinden doğan hak ve yükümlülüklerinin sona ermesi gibi sonuçlara sebebiyet verebileceği için mahkemeler haklı olarak madde 531 kapsamında karar verirken oldukça ince düşünmekte ve çoğu zaman davayı feshi gerektirecek bir haklı sebebin bulunmadığı gerekçesiyle reddetmektedir. ${ }^{303} \mathrm{Bu}$ durum uygulamada nitelikli haklı sebeplerin varlığında dahi azınlık pay sahiplerinin haklı sebeple fesih davası açmaktan kaçınmalarına yol açmaktadır.

$\overline{303 \text { Hanağası (n 257) } 251 .}$ 
1848 yılında yürürlüğe giren Anonim Şirketleri Tasfiye Yasasından bu yana İngiltere'de yasal bir çözüm olarak haklı gerekçelere dayanan tasfiye davası ${ }^{304}$ mevcuttur. Bu davayla ilgili temel sorun çözüm yolu olarak şirketi sona erdiren tasfiye kararını içeriyor olması ve mahkemenin bu davalarda bu kadar önemli bir kararı vermekte çekingen olmasıyd1. Cohen Komitesi'nin tavsiyeleri ${ }^{305}$ doğrultusunda şirkette baskı gören, ayrımcı davranışlarla karşılaşan davacının hisselerinin satın alınması gibi alternatif çözümler içeren yeni bir dava hakkı İngiliz hukukuna 1947 İngiliz Şirketler Kanununun 9.maddesinde düzenlenen 'Bask1 Durumlarında Tasfiyeye Alternatif Çözüm'306 başlığ́1 altında getirildi. Daha sonra yürürlüğe giren İngiliz Şirketler Kanunlarında (1948, 1980 ve 1985), tasfiye davası ve alternatif çözümler içeren bu yeni dava hakkı aynı kanunlarda düzenlenmiştir ${ }^{307}$. Ancak bu iki dava arasındaki bağlantı alternatif çözüm yollarına başvurulmasını zorlaştırıyordu. Nitekim tasfiye dışında bir karara hükmedilebilmesi için de davacının şirketin tasfiye edilmesinin haklı ve adil olduğunu kanıtlaması gerekiyordu ${ }^{308}$. İşte bu noktada, Jenkins Komitesinin önerileri doğrultusunda 1980 İngiliz Şirketler Kanunun yürürlüğe girmesiyle bu bağlantı ortadan kaldırıldı ve şirketi tasfiyesini haklı göstermeye gerek kalmadan alternatif çözüm yollarına izin verildi ${ }^{309}$. Ve en nihayetinde, tasfiye davasının iflas hukukunun konusu altında incelenmesi gereken bir dava olduğuna karar verilerek, bu dava hakkı Şirketler Kanunundan çıkarılarak 1986 İngiliz İflas Yasası'nın 122/1-g maddesinde düzenleme altına alındı. Tasfiye davası açılabilmesi için şirketin devamlılığını sürdüremeyecek kadar işlerinin kilitlenmiş olması ve tasfiye kararı verilmesinin haklı gerekçelere dayandığının davacı tarafından ispat edilmesi gerekmektedir. Ayrıca İngiliz İflas Kanunu 125/2 maddesine eklenen bir düzenleme ile madde 122 kapsamında tasfiye davası açılabilmesi için ve diğer dava yollarının tüketilmiş olması şartı getirilmiştir.

Ayrıca önerilen şekilde TTK madde 531 'in iki farklı dava hakkı olarak düzenlenmesi durumunda fesih hakkını içermeyen dava hakkının çoğunluk pay sahiplerine karşı da kullanılması mümkün olabilir. Yukarıda da bahsedildiği gibi 531. madde kapsamında açılan bir davada davalı sadece şirket olabilir. Dolayısıyla da dava sonunda mahkeme tarafından payların satılmasına karar verilse dahi bu payları satın alacak olan sadece şirketin kendisidir. Yargıtay' ın çoğu kararı da bu yöndedir ${ }^{310}$. Fesih sonucu içeren bir davada böyle olması kabul edilebilir bir durumdur. Ancak fesih hakkını içermeyen bir davada çoğunluğa karşı da haklı sebeplerin varlığında dava açılabilmesi veya dava

\footnotetext{
304 just and equitable winding up

${ }_{305}$ Board of Trade, 'Report of the Committee on Company Law Amendment' (Cmd 6659, 1945) (Cohen Report, 1945).

306 Alternative Remedy to Winding Up in Cases of Oppression

307 Veziroğlu (n 9) 532.

308 Birds ve diğerleri 2014, 659.

309 Board of Trade, 'Report of the Company Law Committee' (Cmnd 1749, 1962).

310 Yargitay 11 HD, 211/8872, 17.11.2016; Yargitay 11 HD, 9088/2352, 03.03.2016; Yargitay 11 HD, 3669/10238, 02.06.2014; Yargitay 11 HD, 4504/12890 03.12.2015; Yargitay 11 HD, 17416/12331, 19.11.2015; Yargitay 11 HD, 14221/3922, 20.06.2017; Yargitay 11 HD, 2552/5272, 11.10.2017; Yargitay 11 HD, 4245/6420, 22.11.2017.
} 
sonunda çoğunluk pay sahiplerince azınlığın paylarının iktisabına karar verilmesi düşünülebilecektir.

Anıldığı üzere anonim şirketin haklı nedenle feshi davasının temel işlevlerinden birisi de çoğunluk ilkesinin geçerli olduğu anonim şirketlerde çoğunluğun elinde bulundurduğu gücü kötüye kullanmasına karş1 azınlığı korumak ve pay sahipleri arasındaki menfaat ihtilaflarını çözümleyerek şirketin işleyişini sürdürmesini sağlamaktır $^{311}$. Önerildiği şekilde, madde 531'in fesih içeren ve içermeyen iki farklı dava olarak düzenlenmesi durumunda fesih içermeyen yeni dava hakkının en temel işlevi ve amac1 çoğunluk pay sahiplerinin gücünü kötüye kullanması ihtimaline karş1 azınlığın korunması olacaktır. Nitekim amacını gerçekleştirmekte zorlanan şirketin fesih yoluyla sona ermesi artık fesih içeren dava hakkının işlevi olacaktır. Önerildiği gibi davaların tekrar düzenlenmesi halinde, fesih hakkı içermeyen dava hakkının daha çok küçük ölçekli ve hissedarları arasında kişisel ilişkiler bulunan şirketlerdeki pay sahiplerince kullanılacağı söylenebilir. Nitekim daha büyük ölçekli şirketlerdeki hissedarların paylarını arzu ettikleri bedelle uygun bir alıcıya devretmeleri daha kolaydır. Dolayısıyla bu davayı açma gereksinimleri olmayacaktır.

Belirtmek gerekir ki, bu makalede yer alan öneriler oldukça köklü değişiklikler gerektirmektedir ve daha ayrıntılı tartışmalarla ve analizlerle desteklenmesi gerekmektedir. Bu da ancak bu hususta yapılacak olan yeni çalışmalar ile mümkün olacaktır.

\section{Sonuç}

Bu makalede İngiltere'de azınlık pay sahipleri için sağlanan yasal koruma yolları tarihsel süreçleri ve dava örnekleri de kapsayacak şekilde analiz edilmiştir.

İngiliz hukukunda azınlık pay sahiplerinin korunmasının gelişiminin yıllar aldığ 1 ve bu gelişim sürecinin hala devam etmekte olup birtakım sorunların mevcut olduğu bu makalede ortaya konulmuştur. Nitekim azınlık pay sahipleri kendilerine tanınan yasal koruma yollarına başvururken bir takım karmaşı prosedürlerle karşılaşmakta ve yargılama giderlerinin kendilerine yükletilmesi gibi zorluklar ortaya çıkmaktadır. Her ne kadar 2006 tarihli İngiliz Şirketler Kanunu ile yazılı düzenleme alanı bulan "türev dava" ve yeniden düzenlenen "haksız ayrımcılık davası" azınlık pay sahiplerine şirket içerisinde karşılaştıkları sorunlara karşı önemli ölçüde hukuki koruma sağlıyor olsa da hala bir takım belirsizlik ve sorunlarla karşılaşabildiği ortadadır. İngiliz dava hukukunda her geçen gün yeni içtihatlar ile mahkemeler bu sorunların çözümüne katkı sağlamaktadır.

311 Özlem İlbasmış Hızlısoy, Anonim Şirketin Haklı Sebeple Feshi (1. Bası, Adalet 2016) 37-40. 
Bu makalede ayrıca Türk hukuku ile İngiliz hukuku arasında azınlık pay sahiplerine tanınan dava hakları temelinde bir kıyaslama yapılmış ve Türk hukukunda azınlık pay sahiplerine tanınan haklara ilişkin değerlendirmeler yapılarak bazı öneriler sunulmuştur. Bu bağlamda, öncelikle TTK'da düzenlenen yönetim kurulu üyelerinin sorumluluk davası, İŞK 260 ve devamında yer alan türev dava ile kıyaslanmış ve devamında TTK madde 531'de düzenlenen haklı sebeple fesih davası analiz edilerek bu davanın İngiliz hukukunda doğrudan bir karşılığının bulunmadığı ifade edilmiştir. Ancak yargılama sonunda verilen tasfiye kararı, davacının paylarının satılarak bedelinin davacıya ödenmesi suretiyle pay sahibinin şirketten çıkarılması ve davanın başvuru koşulları gibi hususlar birlikte düşünüldüğünde, İngiliz İflas Yasası 1986'nın 122 (1) (g) maddesinde yer alan tasfiye davası ve İŞK 994'te düzenlenen haksız ayrımcılık davasının birlikte TTK madde 531'de yer alan haksız sebeple fesih davasına karşılık gelebileceği ifade edilmiştir. Yine bu değerlendirmelere istinaden haklı sebeple fesih davasıyla ilgili uygulamada karşılaşılan sorunlar analiz edilmiş ve bu azınlık hakkına ilişkin öneriler sunulmuştur.

Hakem Değerlendirmesi: Dış bağımsız.

Çıkar Çatışması: Yazar çıkar çatışması bildirmemiştir.

Finansal Destek: Yazar bu çalışma için finansal destek almadığını beyan etmiştir.

Peer-review: Externally peer-reviewed.

Conflict of Interest: The author has no conflict of interest to declare.

Grant Support: The author declared that this study has received no financial support. 


\section{Bibliyografya/Bibliography}

Ahern D, 'Directors' Duties: Broadening The Focus Beyond Content To Examine The Accountability Spectrum' (2011) 33 Dublin University Law Journal 116-152.

Alcock A, J Birds ve S Gale, Companies Act 2006 (1. Bas1, Jordan Publishing 2009).

Almadani M, 'Derivative actions: does the Companies Act 2006 offer a way forward?' (2009) 30 Company Lawyer 131.

Ayan Ö, 'Yeni Türk Ticaret Kanunu'nda Anonim Şirketin Haklı Sebeplerle Feshi Davası (531. Madde)' (2011) 9 Legal Hukuk Dergisi 102.

Bahtiyar M, Ortaklıklar Hukuku (10. Bası Beta 2014).

Bilge M E, 'Anonim Şirketin Sona Ermesi ve Tasfiyesi' (2012) 16 Erzincan Üniversitesi Hukuk Fakültesi Dergisi 3, 261-294.

Bilgili F ve Demirkap1 E, Şirketler Hukuku Dersleri (6. Bası, Dora 2018).

Birch v Sullivan [1957], 1 WLR 1247.

Boyle A.J, Birds J ve Diğerleri, Boyle \& Birds' Company Law (9. Bası, Jordan Publishing 2014).

Bourne N, Bourne on Company Law (6. Bas1, Routledge 2013).

Bridge v Daley [2015], EWHC 2121 (Ch).

Burland v Earle [1902], AC 83.

Can M Ç, 'Pay Sahiplerinin veya Alacaklıların Doğrudan Zararlarının Tazmini Amacıyla İkame Edilen Sorumluluk Davalarında TTK m.1534'ün Etkisi' (2017) 21 Galatasaray Üniversitesi Hukuk Fakültesi Dergisi (GÜHFD) 4, 10-12.

Cinematic Finance Ltd v Ryder and others [2010], EWHC 3387 (Ch).

Cook v Deeks [1916], 1 AC 554.

Cooke v Cooke [1997], 2 BCLC 28.

Cullen Investment Ltd v Brown [2015], EWHC 473 (Ch).

Çamoğlu E, 'Anonim Ortaklığın Haklı Sebeple Feshinde Hâkimin Takdir Yetkisi’ (2015) 31 BATIDER 1 .

ÇELIK A, Anonim Şirketlerde Ortaklıktan Çıkarılma, (3. Bası, Seçkin 2016).

Davies P.L ve Worthington S, Gower \& Davies Principles of modern company law (9. Bas1, Sweet \& Maxwell, 2012).

Dignam A ve Lowry J P, Company Law (5. Bas1, Oxford University Press 2009).

Dignam A ve Lowry J P, Company Law (8. Bas1, Oxford University Press 2014).

Dignam A, Hicks A ve Goo S H, Hicks \& Goo's Cases and Materials on Company Law (Oxford University Press 2011).

Domaniç H, Anonim Şirketler / Joint Stock Companies (1. Bası, Eğitim 1978).

Ebrahimi v Westbourne Galleries Ltd [1973], AC 360.

Erdem N, Anonim Ortaklı̆̆ı Haklı Sebeple Feshi (2. bask1, Vedat 2019).

Edwards v Halliwell [1950], 2, All ER 1064.

Erten C, 'Anonim Şirketlerde Haklı Sebeplerle Fesih Hakkının Yargıtay İçtihatları Çerçevesinde Değerlendirilmesi’ (2019) 13 Uyuşmazlık Mahkemesi Dergisi, 187-211.

Faybird Group Ltd v Greenwood [1986], BCLC 319327.

Fisher v Cadman [2006], 1 BCLC 499. 
Foss v Harbottle [1843], 67 ER 189.

French D, Mayson S ve Ryan C, Mayson, French \& Ryan On Company Law (30. Bas1, Oxford University Press 2013).

Grace v Biagiol [2006], 2 BCLC 70.

Griffin S, 'Alternative Shareholder Remedies Following Corporate Mismanagement- Which Remedy To Pursue?' (2017) 281 Company Law Newsletter 1-4.

Güngör S, ‘6102 Sayılı Türk Ticaret Kanunu Hükümleri Kapsamında Anonim Şirketlerde Azınlığa Tanınmış Olan Haklar' (2015) Tekirdağ SMMM Odası Sosyal Bilimler Dergisi, 4, 4.

Hecquet v McCarthy [2006], EWHC 832 (Ch).

Helvacı M, 'Yönetim Kurulu Üyelerinin Hukuki Sorumluluğunda Farklılaştırılmış Teselsül' (2013) Prof. Dr. Oğuz İmregün'e Saygı Sempozyumu, 2 Galatasaray Üniversitesi Hukuk Fakültesi Dergisi (GÜHFD).

Hannigan B, Company Law (4. Bas1, Oxford University Press 2013).

Hallington R, 'Oppression of Minority Shareholders: Reflections on Blisset v Daniel' (2007) 19 Denning Law Journal 5.

Helvacı M, Anonim Ortaklıkta Ticaret Kanunundan Kaynaklanan Azınlık Haklarının Hukuki Niteliği ve Tanımı, Prof. Dr. Oğuz İmregün'e Armağan (Beta, 1998).

Hollington R, Hollington on Shareholders'Rights (8. Bas1, Sweet \& Maxwell 2016).

Hutton v West Cork Railway Co. Ltd (1883), 23, Ch. D 654.

Iesini v Westrip Holdings Ltd [2009], EWHC 2526 (Ch).

Irvine v Irvine (No 1) [2007], 1 BCLC 349.

İlbasmış Hızlısoy Ö, Anonim Şirketin Haklı Sebeple Feshi (1. Bası, Adalet 2016).

Joffe V, Minority Shareholders: Law, Practice and Procedure (1. Bas1, Oxford University Press 2008).

Karasu R , 'Emredici Hükümler İlkesinin Kapalı Tip Anonim Şirketler ve Limited Şirketler Açısından Doğurduğu Sorunlar Ve Çözüm Önerileri' (2015) Ticaret ve Fikri Mülkiyet Hukuku Dergisi 1.

Keay A ve Loughrey J, 'Derivative Proceedings in A Brave New World For Company Management And Shareholders' (2010) 3 Journal of Business Law 151.

Keay A ve Loughrey J, 'Something old, something new, something borrowed: an analysis of the new derivative action under the Companies Act 2006' (2008) 124 The Law Quarterly Review 469.

Keay A, 'Applications to continue derivative proceedings on behalf of companies and the hypothetical director test' (2015) 34 (4) Civil Justice Quarterly 346-365.

Kendigelen A, 'İptal Davası Açma Hakkı ve Pay Sahipliği Sıfatının Cüz’i Halefiyet (Payların Devri) Sonucu Değişmesi' (2001) 1 Prof. Dr. Hayri Domaniç’e 80. Yaş Günü Armağan1, 307-331.

Kendigelen A, Yeni Türk Ticaret Kanunu: Değişiklikler, Yenilikler ve İlk Tespitler (3. Bası, On İki Levha 2016).

Kershaw D, 'The Rule in Foss v Harbottle is Dead: Long Live the Rule in Foss v Harbottle' (2015) Journal of Business Law 274.

Kim K, Kitsabunnarat-Chatjuthamard P ve Nofsinger J, 'Large Shareholders, Board Independence, and Minority Shareholder Rights: Evidence From Europe’ (2007) 13 Journal of Corporate Finance 859.

Koç H, ‘Anonim Şirket Yönetim Kurulu Üyelerinin Farklılaştırılmış Teselsül İlkesi Uyarınca 
Sorumluluklarına Genel Bir Bakış' (2020) 3 Necmettin Erbakan Üniversitesi Hukuk Fakültesi Dergisi (NEÜHFD), S.1.

La Porta R, Lopez-de-Silanes F, Shleifer A ve Vishny R, 'Law And Finance' (1998) 106 Journal of Political Economy 1113.

Law Commission, ‘Shareholder Remedies' (Law Com. No. 246, 1997), para. 6.4.

Law Commission, ‘Shareholder Remedies' (Law Com. No. 246, 1997), para. 16.1.

Loch v John Blackwood Ltd [1924], AC 783.

MacDougall v Gardiner (1875), 1, Ch. D 13.

McMullen J, 'Minority Protection and Section 75 Of The Companies Act 1980' (1983) 42 The Cambridge Law Journal 204-206.

Milman D, 'Shareholder Law: Recent Developments in Practice' (2015) 378 Company Law Newsletter 1 .

Monks R.A.G, 'Modern Company Law for A Competitive Economy: The Strategic Framework' (2000) 8 Corporate Governance: An International Review 16-24.

Moroğlu E, 6102 Sayılı Türk Ticaret Kanunu (Başlangıç Hükümleri, Ticari İşletme, Ticaret Şirketleri, Kıymetli Evrak ve Son Hükümler) Değerlendirme ve Öneriler (7. Bas1, On İki Levha 2012).

Mujih E C, 'The new statutory derivative claim: a delicate balancing act: Part 1' (2012) 33 (3) Company Law 76.

Nessen P, Goo S.H. ve Low C.K, 'The statutory derivative action: now showing near you' (2008) 7 Journal of Business Law 627-661.

Newington-Bridges C, 'A Practical Guide To Unfair Prejudice Petitions And Their Interaction With Derivative Claims' (Stjohnschambers.co.uk, 2016) <https://www.stjohnschambers.co.uk/wpcontent/uploads/2018/07/Unfair-prejudice-petitions-and-derivative-actions.pdf $>$ Erişim Tarihi $06 / 01 / 2021$.

Nicholas v Soundcraft Electronics Ltd [1993] BCLC 360.

Nomer Ertan F, ‘Anonim Ortaklığın Haklı Sebeple Feshi Davası- TTK m. 531 Üzerine Düşünceler' (2015) 23 İstanbul Hukuk Mecmuası 421.

Nwafor A, 'The unfair prejudice remedy - a relief for the minority shareholders' (2011) 22 University of Botswana Law Journal 37.

Oak Investment Partners XII, Limited Partnership v Boughtwood [2009], 1 BCLC 453.

O’Neill v Phillips [1999], 2 BCLC 1.

Oregum Gold Mining Co. v Roper [1892], AC 125.

Oruç M, ‘6102 sayılı Yeni Türk Ticaret Kanunu’na Göre Anonim Ortaklıktan Haklı Sebeple Fesih İstemine Bağlı Çıkarılma' (2011) 27 Banka Huk. Dergisi 209.

Payne J, 'Sections 459-461 Companies Act 1985 In Flux: The Future of Shareholder Protection` (2005) 64 The Cambridge Law Journal 647.

Pekcanitez H, Atalay O ve Özekes M, Medeni Usul Hukuku (14. Bas1 Yetkin 2013).

Percival v Wright [1902], 2, Ch. 401.

Pettet B G ve diğerleri, Pettet’s Company Law (1. Bas1, Pearson Longman 2009)

Poroy R, Tekinalp Ü ve Çamoğlu E, Ortaklıklar Hukuku (13. Bası, Beta 2014).

Prudential Assurance Co. Ltd v Newman Industries Ltd [1982], Ch. 204.

Radin S, The Business Judgement Rule - Fiduciary Duties of Corporate Directors (5. Bas1, Aspen 
Law and Business 1998).

Redmond-Cooper R, 'Management Deficiencies and Judicial Intervention: A Comparative Analysis' (1988) 9(8) Company Lawyer 169.

Reisberg A, 'Derivative Claims Under the Companies Act 2006: Much Ado About Nothing?' [2009] Rationality In Company Law: Essays In Honour of dd Prentice, J. Armour, J. Payne, Hart Publishing, 2009; University College London Law Research Paper No. 09-02<https://ssrn. com/abstract=1092629> Erişim tarihi 06/12/2020.

Reisberg A, 'Funding Derivative Actions: A Re-Examination Of Costs And Fees As Incentives To Commence Litigation' (2004) 4 Journal of Corporate Law Studies, 346.

Re a Company (No. 003160 of 1986) [1986], BCLC 391.

Re a Company (No 003160 of 1986) [1986], BCLC 391.

Re Blackwood Hodge [1997], 2 BCLC 650, 673.

Re BSB Holdings Ltd (No 2) [1996], 1 BCLC 155.

Re Baumler (UK) Ltd Gerrard v Koby and another [2004], All ER (D) 139.

Re Elgindata Ltd [1991], BCLC 959.

Re London School of Electronics Ltd [1986], Ch. 211.

Re Macro (Ipswich) Ltd [1994], 2 BCLC 354.

Re Posgate \& Denby (Agencies) Ltd [1986], 2 BCC 99.

Re Quickdome Ltd [1988], BCLC 370.

Re RA Noble \& Sons Clothing Ltd [1983], BCLC 273.

Re Ravenhart Service (Holdings) Ltd [2004], 2 BCLC 376.

Re Southern Counties Fresh Foods Ltd [2008], EWHC 2810 (Ch).

Re Sunrise Radio, Kohli v Lit [2010], 1 BCLC 367.

Re Yenidje Tobacco Co. Ltd [1916], 2 Ch. 426.

Sarkar P, 'Common law vs. Civil law: which system provides more protection to shareholders and promotes financial development', (2017) 2 Journal of Advanced Research in Law and Economics 143.

Sealy ve Worthington S, Sealy's Cases and Materials in Company Law (9. Bas1, Oxford University Press 2010).

Seaton v Grant (1867), LR 2, Ch. App. 459.

Sikorski v Sikorski [2012], EWHC 1613 (Ch).

Sime S ve Taylor M, Company Law in Practice (12. Bas1, Oxford University Press 2017).

Sykes J.P, 'The continuing paradox: a critique of minority shareholder and derivative claims under the Companies Act 2006’ (2010) 29 Civil Justice Quarterly 205-234.

Smith v Croft No. 2 [1988], Ch. 114.

Sümer A, ‘Anonim Ortaklıkların Haklı Nedenle Feshi’ (2012) 18 Marmara Üniversitesi Hukuk Fakültesi Hukuk Araştırmaları Dergisi 2, 839-850.

Şahin A, Anonim Ortaklı̆̆ın Haklı Sebeple Feshi (1. Bası, Vedat 2013).

Şener O H, Teorik ve Uygulamalı Ortaklıklar Hukuku (3. Bası, Seçkin 2017).

Tandoğan H, 3. Şahsın Zararının Tazmini [Mesuliyet] (1. Bası, Ankara 1963) 98; Ahmet Kılıçoğlu, Borçlar Hukuku Genel Hükümleri (20. Bası, Seçkin 2016).

Tang J, 'Shareholder remedies: demise of the derivative claim?' (2012) 1 (2) UCL Journal of Law 
and Jurisprudence 178.

Tekinalp Ü, 'Anonim Ortaklı̆̆ın Haklı Sebeplerle Feshi Davasının Bazı Usulî Sorunları', Ersin Çamoglu'na Armağan (1. Bas1, Vedat 2013).

Tekinalp Ü, 'Türk Ticaret Kanunundaki Boşluk: Anonim Ortaklığın Feshi, Çoğunluk Gücünün Kötüye Kullanılmasına Karşı Etkili Bir Araç' (1974) 21 İktisat ve Maliye Dergisi 8, 321.

UK Companies Act 2006 <https:// https://www.legislation.gov.uk/ukpga/2006/46/section/996> Erişim Tarihi 06/12/2020.

Veziroğlu C, 'Buy-Out of the Oppressed Minority's Shares in Joint Stock Companies: A Comparative Analysis of Turkish, Swiss and English Law' (2018) 19 European Business Organization Law Review 527.

Wallersteiner v Moir [1974], 1 WLR 991.

Wilson v Jaymarke Estates Ltd [2007], UKHL 29.

Wood v Odessa Waterworks Co. (1889), 42, Ch. D 636.

Worthington S, Sealy and Worthington's Text, Cases and Materials in Company Law (11. Bas1, Oxford University Press 2016).

Yanlı V, 'Şirkete Verilen Zarar Sebebiyle Sorumluluk Bağlamında "Yönetici” Kavramı ve Genel Kurul Kararı Gerekliliği Sorunu’ (2019) 141 Terazi Hukuk Dergisi 51, 46-57.

Yasaman H, 'Türk Ticaret Kanunu Tasarısı'nda Hâkimin Genişleyen Rolü’ (2009) 25 BATIDER 4, 73. 
